\author{
GÖTTINGER ZENTRUM \\ FÜR BIODIVERSITÄTSFORSCHUNG UND ÖKOLOGIE \\ - Göttingen Centre for Biodiversity And Ecology -
}

\title{
Diversity and tree neighborhood effects on the growth dynamics of European beech and the stand seed bank in temperate broad-leaved forests of variable tree diversity
}

\author{
Dissertation zur Erlangung des Doktorgrades der \\ Mathematisch-Naturwissenschaftlichen Fakultäten der \\ Georg-August-Universität Göttingen
}

vorgelegt von

Diplom-Ingenieurin

Inga Mölder

aus

Magdeburg

Göttingen, Februar 2009 
Referentin/Referent:

Korreferentin/Korreferent:

Tag der mündlichen Prüfung:
Prof. Dr. C. Leuschner

Prof. Dr. S. Zerbe

13. März 2009 

Chapter 1: Introduction 3

Biodiversity research in forests $\quad 4$

Investigations of long-term biodiversity effects 5

Mechanisms ruling forest dynamics $\quad 5$

$\begin{array}{ll}\text { Study site } & 7\end{array}$

Study design 8

Study objectives and hypotheses 10

References 12

Chapter 2: Structure and composition of the seed bank in monospecific and tree species-rich temperate broad-leaved forests

$\begin{array}{ll}\text { Abstract } & 16\end{array}$

Introduction 16

$\begin{array}{ll}\text { Study site } & 17\end{array}$

$\begin{array}{ll}\text { Methods } & 17\end{array}$

$\begin{array}{ll}\text { Statistical analyses } & 17\end{array}$

$\begin{array}{ll}\text { Results } & 18\end{array}$

$\begin{array}{lr}\text { Tree species diversity and seed bank composition } & 18\end{array}$

$\begin{array}{ll}\text { Similarity between seed bank and actual vegetation } & 18\end{array}$

$\begin{array}{ll}\text { Sociological groups represented in the seed bank } & 19\end{array}$

$\begin{array}{ll}\text { Plant functional types in the seed bank } & 19\end{array}$

Qualitative changes in the seed bank composition between species-poor and rich stands 20

Factors influencing size and composition of the seed bank 20

Discussion 21

Correspondence between actual vegetation and seed bank composition 21

$\begin{array}{ll}\text { Variables affecting tree species diversity and seed bank } & 21\end{array}$

Relationships between tree-species diversity or identity and the seed bank 22

Conclusion $\quad 22$

References $\quad 22$ 
Chapter 3: Beech grows better and is less drought-sensitive in speciesrich than in pure stands - tree neighbourhood effects on the radial increment of Fagus sylvatica

$\begin{array}{ll}\text { Abstract } & 25\end{array}$

Introduction $\quad 26$

Material and methods $\quad 27$

$\begin{array}{ll}\text { Study sites } & 27\end{array}$

Selection of tree individuals $\quad 28$

$\begin{array}{ll}\text { Stem coring and dendrochronological analyses } & 29\end{array}$

Statistical analyses $\quad 30$

Results 31

Beech stem increment and canopy structure as influenced by clay content 31

Beech stem increment in the neighbourhood of conspecific or allospecific trees 34

Beech stem increment in the neighbourhood of different species 36

Discussion 38

Tree-species diversity and forest productivity 38

The role of competition in tree neighbourhood effects on growth 39

Facilitation and other possible mechanisms of interaction 40

Neighbourhood effects on stress sensitivity and resilience of growth 41

Stand density and forest management effects on growth 42

The role of the neighbour's species identity 42

$\begin{array}{ll}\text { Conclusions } & 43\end{array}$

References $\quad 44$

Chapter 4: $\delta^{13} \mathrm{C}$ signature of tree rings and radial increment of Fagus sylvatica trees as dependent on tree neighborhood and climate $\quad 48$

$\begin{array}{ll}\text { Abstract } & 49\end{array}$

Introduction $\quad 50$

Methods $\quad 51$

Study site $\quad 51$

Tree selection and neighborhood characterization 52

Sample preparation and analysis $\quad 53$

Statistical methods $\quad 54$

Results $\quad 57$

Beech stem increment and $\delta^{13} \mathrm{C}$ signatures as dependent on climatic parameters $\quad 57$

Relationship between $\delta^{13} \mathrm{C}$ signals and annual radial increment 58

Beech stem increment and $\delta^{13} \mathrm{C}$ signals as influenced by competition intensity and
neighborhood diversity

Effect of age and temporal changes in radial increment and $\delta^{13} \mathrm{C} \quad 61$

Discussion 62

Correlation of climate parameters with tree ring $\delta^{13} \mathrm{C}$ signatures and radial increment $\quad 62$

$\delta^{13} \mathrm{C}$ in tree rings as dependent on competition intensity 64

Competition with conspecific vs. competition with allospecifics neighbor trees $\quad 65$

$\begin{array}{ll}\text { Long-term trends in } \delta^{13} \mathrm{C} \text { and stem increment } & 67\end{array}$

$\begin{array}{ll}\text { References } & 70\end{array}$ 


\section{Table of contents}

Chapter 5: Synthesis

Processes altering tree-species diversity and biotic long-term archives at the same time

Has tree-species diversity an effect on biotic archives of forest ecosystem processes?

The soil seed bank

Radial increment of trees

Evaporative demand of trees as indicated by $\delta^{13} \mathrm{C}$ signatures

76

76

77

Effects of tree-species diversity on reaction of Fagus to disturbances

References

Acknowledgments

Curriculum vitae 



\section{Summary}

Among the recent studies investigating species diversity's effect on ecosystem functioning, only few examine long-term changes. My study addresses this question based on seed bank analysis and dendrochronology in temperate deciduous forest stands in Hainich National Park (Thuringia, Germany). I focused on three main hypotheses i) species identity of the neighbor trees and their functional traits can significantly influence growth dynamics of Fagus sylvatica L. and the soil seed bank, while species diversity of the neighborhood is of no significance, ii) neighborhood diversity alters trees' capacity of reaction to disturbances, and iii) there are processes altering tree species diversity, growth patterns of $F$. sylvatica and the soil seed bank at the same time.

The selected 12 forest stands, situated on similar bedrock, represent a gradient in tree species diversity. Samples were taken from monospecific beech stands (DL1), medium-diverse forests with beech, ash, and lime (DL2), and highly diverse stands dominated by beech, ash, lime, maple, and hornbeam (DL3). I investigated germinating seeds in three horizons $(0-5 \mathrm{~cm}, 5-10 \mathrm{~cm}, 10-20 \mathrm{~cm})$ of the soil seed bank and determined seed density, composition and functional types of species. Furthermore, structural parameters of target Fagus trees and their neighbors were analyzed. Neighborhoods of target trees were grouped according to the relative importance of intraspecific competition by Fagus: from purely conspecific neighborhoods (Fagus100) to neighborhoods with mainly conspecific neighbors and few allospecific competitors (Fagus70-99) to neighborhoods with more than $30 \%$ of the canopy's influence sphere occupied by allospecific trees (Fagus $<70$ ). I examined tree-ring width and growth response to, as well as recovery from, selected stress events (negative pointer years). In addition, I studied $\delta^{13} \mathrm{C}$ signatures of tree rings as proxy for stomatal conductance.

The seed bank of stands with moderately diverse and highly diverse tree layer is not only richer in species than the monospecific stands, but also in the number of germinable seeds. In spite of the strong correlation found between tree- and herb-layer diversity in the stands, an indirect effect of treelayer diversity or tree species identity on the seed bank via herb-layer composition could not be confirmed due to the poor correspondence between herb-layer composition and seed bank structure. The effect exerted by certain tree species on litter quality and decomposition rates had a stronger influence on the seed bank, which is indicated by the strong negative correlation between seed bank size and litter layer thickness.

The impact of neighborhood diversity was also visible in Fagus trees showing higher mean radial stem growth rates when they were surrounded by a number of other tree species. My study is among the first that obtained evidence for a species-specific neighborhood effect on the current wood increment rate of a target species in natural forests. Tree-species identity and the contribution of different species to the competition index $(\mathrm{Cl})$ of a Fagus neighborhood were more important than the magnitude of $\mathrm{Cl}$ itself. Beeches with a few allospecific neighbors (Fagus70-99 category) showed less severe growth reduction in the negative pointer year 1976 than beeches in pure stands. They also recovered more rapidly in terms of stem increment after the severe 1976 drought. The buffering effect of allospecific neighborhoods with regard to environmental hazards could explain this finding. 
In the period from 1926 to 1975 , beech predominantly surrounded by conspecifics (Fagus100, Fagus70-99) reached higher values of $\delta^{13} \mathrm{C}$ than beech largely affected by allospecific competitors (Fagus $<70$ ). On the contrary, values of the more actual period 1976 to 2005 did not vary between the neighborhood classes. This leads to the conclusion that target trees, today surrounded by allospecific neighbors, probably benefited from thinning in order to promote growth of other valuable broad-leaved tree species. Thinning resulted in an increase in available soil water and growth. This increase in soil water is manifested in relatively smaller $\delta^{13} \mathrm{C}$ values in the largely allospecific Fagus $<70$ neighborhoods. The effect vanished when the canopy closed again. Hence, the observed $\delta^{13} \mathrm{C}$ pattern is probably rather a secondary effect of forest management than a direct effect of neighborhood diversity on water supply of Fagus.

Disturbance regime, forest management and stand age are important for ecosystem processes in forests. They leave detectable traces in the soil seed bank, tree-ring width and $\delta^{13} \mathrm{C}$ series. Generally, I assume that the neighborhood represents an environmental factor of lower importance than other factors controlling annual ring width, as there are soil conditions and light availability. Thus, the neighborhood may influence the growth response under certain conditions, but this factor is too weak to determine principal types in the growth-environment relationship of Fagus. 
Chapter 1

Introduction 


\section{Introduction}

\section{Biodiversity research in forests}

Biodiversity or biological diversity is not only the sum of all species but also includes genetic variability and the variety of habitats (Convention on Biological Diversity 1992). The UN biodiversity conference in Bonn, Germany in 2008 confirmed the targets of the 1992 Rio Summit, including intensified attempts to evaluate the consequences of biodiversity loss. Before consequences of biodiversity loss can be quantified, biodiversity effects have to be investigated. The idea of biodiversity research roots back to studies as early as Darwin's Origin of the Species and focused on direct use values of species, for example as food or medicine, or biodiversity-ecosystem functioning relationships. Ecosystem processes like nutrient cycling or productivity were related to number of species or functional types.

During the last years, increased efforts have been undertaken to extend the area of mixed species stands in forestry, in particular in Central Europe (see Knoke et al. 2005). Effects on long-term changes in stand and growth dynamics linked to biodiversity are only scarcely studied since the majority of studies were focused on ecosystems other than forests with short-lived species (e.g., Loreau et al. 2002). Processes and ecosystem functioning are comparatively well studied in twospecies mixtures of trees (e.g., Cannell et al. 1992; Berger et al. 2004; Pretzsch \& Schütze in press) while multi-species approaches are rare. First mentioned studies revealed that, on average, productivity in mixed stands can be higher than in pure stands (overyielding), but systematic differences exist that largely depended on tree species identity, site and tree age (Kerr et al. 1992). Further explanations for overyielding in mixed stands consider more intense rooting in mixed forests, more rapid mineralization of mixed litter, decreased herbivory or increased protection from late frost events in the presence of conifers (Kerr et al. 1992). To a great extent, species most relevant for wood production were studied, in Central Europe particularly Norway spruce (Picea abies (L.) H. Karst.) and European beech (Fagus sylvatica L.). Information on admixed species such as sycamore maple (Acer pseudoplatanus L.) and lime (Tilia spec.) and their effects on ecosystem functioning are remarkably deficient.

Recently, long-term research projects have been initiated, which are designed to study biodiversity-ecosystem relationships in newly planted perennial tree plantations of the tropics, boreal and temperate regions (see Scherer-Lorenzen et al. 2005). These experiments offer the possibility of manipulating tree diversity under relatively controlled conditions. Even if statistical analyses become easier, since covariables such as stand history and soil conditions do not have to be considered or at least are controlled, transferability of findings to natural systems is still not guaranteed. In addition, results on mature forests may only be expected in several decades. Consequently, observational studies on mature forests are needed to complete knowledge of ecosystem functioning in forests (Underwood \& Paine 2007; Leuschner et al. 2009). 


\section{Investigation of long-term biodiversity effects}

Longevity of woody communities is an advantage for studying long-term effects of biodiversity. Especially long-lived trees witnessed and "recorded" forest dynamics and therefore seem suitable for the investigation of long-term biodiversity effects on individual trees. In my study, I use analysis of the soil seed bank and dendrochronology to evaluate long-term effects of plant-species diversity. Investigations on effects of non-woody plant-species diversity on ecosystem stability parameters, such as resistance to disturbance, resilience, and stability, point towards a greater resistance to extrinsic disturbance (e.g., Tilman \& Downing 1994; Tilman 1996; Joshi et al. 2000). Some of these experiments showed that temporal variability of above-ground biomass in disturbed plots was smaller on species-rich than on species-poor sites (Cottingham et al. 2001; Loreau et al. 2002). Effects of woody species diversity are not so well studied on the level of individual trees. Given the longevity of trees, small differences in functional traits may accumulate comparable to a compound interest effect and become effective even within the life of an individual (Körner 2005).

Further information on past and recent biodiversity effects on plant-plant systems can be retrieved from the analysis of the soil seed bank. While dendroecology mainly gives information on life history of individual trees, seed banks contain a broader information range including traces of a large part of the vegetation cover. Seeds of some plants can persist for more than a century in the soil (Telewski \& Zeevaart 2002). However, in general, stand aging causes seed bank depletion, but disturbances, e.g., due to management, allow regeneration of early successional species and the replenishment of the seed bank (Bossuyt \& Hermy 2001). Agestochoric species as Juncus effusus L. can give hints on management intensity (Decocq et al. 2004). Nevertheless, the soil seed bank is a completely passive archive depending largely on disturbances that release species. In contrast, trees with their individual tree-ring patterns are not only archives of the neighborhood and its dynamics but also actively alter stand conditions.

\section{MECHANISMS RULING FOREST DYNAMICS}

Succession and disturbance are the two main processes which shape forests and are summarized under the term forest dynamics. Whereas succession is principally a natural process, disturbances are widely caused by windthrow, and, in Central Europe, by forest management. If the climax stage of succession is reached, predominant species replace themselves rather than being substituted by new invading species (Cowles 1911; Daubenmire \& Daubenmire 1968; Oliver \& Larson 1990) or late successional, usually shade tolerant, species become dominant (Egler 1954; Oliver 1981; Oliver \& Larson 1990; Ellenberg \& Leuschner 2009).

Changes in stand structure patterns are the result of interactions between trees. In mature, mixed stands some tree species grow rapidly in their youth and hence, gain dominance locally or in the stand after disturbance (Garber \& Maguire 2004). In European forests, Fraxinus excelsior L. is an exemplary species for this pioneer strategy. Late successional species, such as Fagus sylvatica L., are characterized by a slower growth but great shade-tolerance and the ability to outcompete other 
trees by shading if they manage to overtop them (Hein et al. 2008). Depending on growth parameters of the involved species, a vertical stratification or temporal niche differentiation occurs. In general, two differing main processes of interaction - mutualism and competition - have been used to explain forest development patterns. Probably both processes exist; while coevolution and predictable associations of tree species suggest mutualism, resilient behavior of logged and managed stands supports the concept of competition (Oliver \& Larson 1990).

Stem density and crowding by neighbor trees are the best studied structural stand factors influencing the radial increment of trees (e.g., Hegyi 1974; Tome \& Burkhart 1989; Vacek \& Lepš 1996; Weber et al. 2008), whereas the impact of neighbor tree species is scarcely studied. Productivity, namely radial increment, is determined by climatic parameters and ontogenetic incidents, such as masting events, as well as by competition. Of these factors, competition affects increment by altering water, light and nutrient availability, but also by changing the effect mechanisms of extrinsic factors such as climate signals (Piutti \& Cescatti 1997).

In the framework of dendrochronological studies, asymmetry between species has been observed as well as symmetry (Frech 2006; Canham et al. 2006). In this context, minor niche overlapping is a precondition for significant biodiversity effects on productivity and other ecosystem functions (Nijs \& Roy 2000). Hence, diversity effects are analyzed with regard to effects of species and their functional traits. For example belowground niche differentiation, as manifested in different rooting depths, can lead to clear advantages for deeper-rooting species being more resistant to drought (Körner 2005). Aboveground competition traits, such as shape, architecture and density of tree crowns, strongly modifies the way trees intercept solar radiation and interact with wind, temperature and precipitation (e.g., Smith et al. 1997; Körner 2005). Differences in crown architecture (and light penetration) contribute to positive mixture effects on productivity ("overyielding", Kelty 1992; Pretzsch \& Schütze in press).

Studies on the soil seed bank are closely linked to studies on the herb layer. While general canopy density influences the light household of lower forest layers considerably, vertical crown stratification affects understory vegetation by altering sunfleck distribution (Canham et al. 1994). In addition, trees alter availability of water and soil nutrients (Légaré et al. 2002; Augusto et al. 2002; Barbier et al. 2008). Hence, with increasing dominance of late successional species with a dense crown, light-demanding species disappear from the forest floor. Litter of dominant trees has considerable effects on forest floor vegetation by altering physical characteristics and soil fertility (Facelli \& Pickett 1991a; Eriksson 1995; Augusto et al. 2002; Barbier et al. 2008; Leck et al. 2008). Consequently, succession in the overstory is closely linked with understory plant communities. While species from early light stages disappear, their long-lived seeds persist in the soil seed bank (Berger et al. 2004). Because shade-tolerant species are largely absent from the seed bank, increasing stand age is connected with a decrease in seed density (Brown \& Oosterhuist 1981; Warr et al. 1994). Seed stratification in the soil gives, among others, information on the period of seed storage (Thompson et al. 1997; Bekker et al. 1998). 


\section{Study site}

The study was conducted in the broad-leaved forests of Hainich National Park (western Thuringia, Central Germany) close to the village of Weberstedt (5105'28'N, 1031'24"E) at about $350 \mathrm{~m}$ elevation. An annual mean temperature of $7.5^{\circ} \mathrm{C}$ and precipitation per year of about $590 \mathrm{~mm}$ (19732004, Deutscher Wetterdienst Offenbach, Germany) characterize the study area. Selection criteria of the study plots were comparability of the sites in terms of edaphic and climatic conditions, a closed canopy, a more or less homogenous stand structure, tree species richness and tree-layer composition. I analyzed tree species richness on three diversity levels (DL). For each diversity level, four representative plots (labeled with $a, b, c$, and $d$ ) were chosen at a maximum distance to each other of $4.9 \mathrm{~km}$. The plots had a size of $50 \mathrm{~m}$ by $50 \mathrm{~m}$ and plots $a$ to $c$ were fenced in 2005 to exclude disturbance by deer, wild boar and human trampling. Because the present study is part of the research program of the Research Training Group ("Graduiertenkolleg") 1086 The role of biodiversity for biogeochemical cycles and biotic interactions in temperate deciduous forests funded by the DFG (German Research Foundation), the study sites are identical to the ones defined by Leuschner et al. (2009).

Dominant forest communities are the Galio-Fagetum and the Hordelymo-Fagetum, i.e. beech forest associations on slightly acidic to basic soils, and the Stellario-Carpinetum, a broad-leaved mixed forest rich in hornbeam, linden and ash (Mölder et al. 2006). All plots were situated on eutrophic loessderived soils with a profile depth of about $60 \mathrm{~cm}$ and are positioned in level or gently sloping terrain. The bedrock beneath the loess-clay layer is limestone (Triassic Upper Muschelkalk). According to the World Reference Base for Soil Resources (WRB), the soil type of the research sites is (stagnic) Luvisol.

First analyses of Hainich National Park's history (Mund 2004) revealed the following differentiation of early forest-historical periods: Until the 17th century selective wood extraction and woodland grazing ("Plünderwald") were predominating, from 1600 to the second half of the 19th century forest was harvested as coppice with standards (Mittelwald) combined with woodland grazing and litter utilization.

During the 1920's a transition from the coppice-with-standards system to selective cutting ("Plenterung") began in large parts of the Hainich forest. Since we can find a pattern of many different owners, historical forest use is greatly variable within small areas (Fig. 1). While three sites (DL3a and DL3b in the "Lindig", and DL1d in the "Lichte Hart") belonged to feudal estate (von Goldacker) in the early 20th century, the majority of the study plots lay in the city-owned forest of the nearby city Bad Langensalza (DL1a, DL1b, DL2a, DL2b, DL2c, DL2d, DL3a, and DL3d). Plot DL1c belonged to a cooperatively owned forest, a so-called "Laubgenossenschaft". After 1949, the investigated sites were mainly managed in a selective cutting system by the state forest administration. After an ample military training area was established in the Hainich region in 1965, large districts of forest became extensively managed. On the other hand, several hundred hectares of forest were clear-felled in order to create firing ranges. In 1990, the area became property of the federal forestry administration. Since end of 1997, all sites belong to the Hainich National Park and were henceforth excluded from forest 
management operations. In spite of an obvious transition towards natural forest conditions, most of the research stand research sites still show characteristics of the ancient coppice-with-standards system and the multiple aged forest system "Plenterwald". Especially the stands DL3a and DL3b remained both largely unmanaged due to the vicinity of firing ranges. They retained structural characteristics of a coppice-with-standards forest. To summarize: for the last 40 years, only single stems have been extracted from the investigated stands, which have been bearing deciduous forest for a period of at least 200 years. Thus, they represent ancient woodland with respect to stand continuity in the definition of Wulf (2003).



Fig. 1: The map shows the research area and the property structure in the early $20^{\text {th }}$ century (basic map provided by K.M. Daenner) (Tree-symbol: cooperative forest "Laubgenossenschaft"; emblem with three towers: property of the city Bad Langensalza; coat of arms with goat: feudal property "von Goldacker").

\section{Study design}

In each of the 12 plots, six $25 \mathrm{~m}^{2}$ subplots $(5 \mathrm{~m} \times 5 \mathrm{~m}$ ) were randomly selected along three 30 - $\mathrm{m}$-long transects that themselves were placed by random into the plots. For the purpose of characterizing tree-layer diversity, the Shannon-diversity index H' was calculated for each study plot based on the number of stems of all canopy-layer trees being present. Plots of DL1 consist nearly exclusively of Fagus sylvatica L. (European beech); DL2 harbors four dominant tree species: Fagus sylvatica, Fraxinus excelsior L. (European ash), Tilia cordata Mill. and T. platyphyllos Scop. (little-leaved and large-leaved linden); DL3 contains seven major tree species: Fagus sylvatica, Fraxinus excelsior, Tilia 
cordata, T. platyphyllos, Carpinus betulus L. (hornbeam), Acer pseudoplatanus L. (sycamore maple), and $A$. platanoides L. (Norway maple).

While samples for the soil seed bank experiment described in Chapter 2 were exclusively taken on the subplots of the fenced plots (Fig. 2), Fagus trees for the dendroecological study were sampled randomly on the plots and in their close neighborhood (Fig. 3).

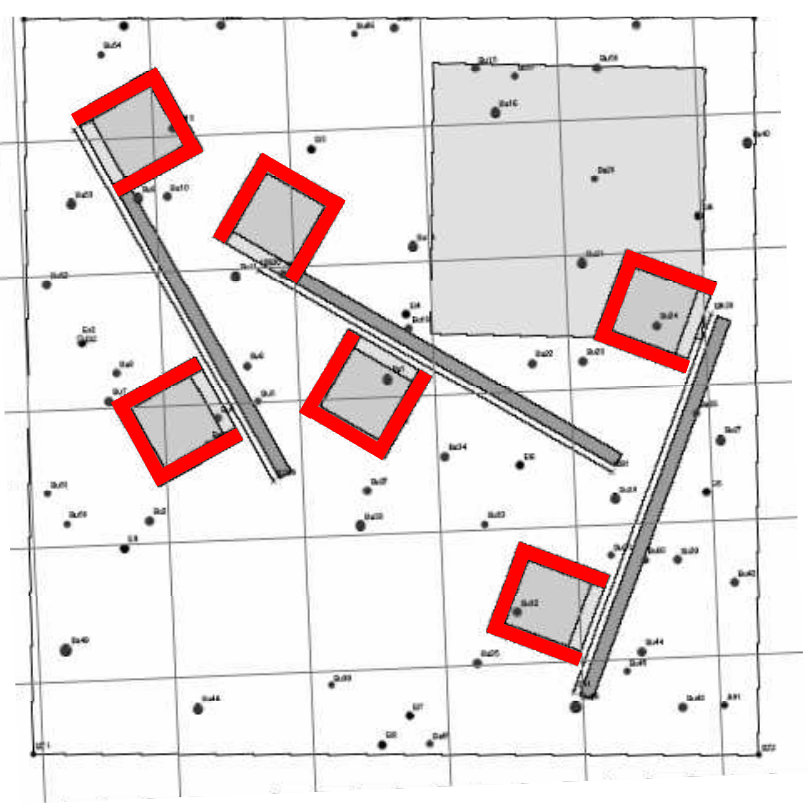

Fig. 2: Sampling scheme for the soil seed bank experiment. Sampling was done on the fenced central study plots within subplots (red areas) along randomly distributed transects.



Fig. 3: Trees for the dendroecological study were sampled in a grid of $150 \mathrm{~m} \times 150 \mathrm{~m}$ around the central study plots.

In this study, following parameters were recorded and analyzed:

- Germinating seeds in three horizons $(0-5 \mathrm{~cm}, 5-10 \mathrm{~cm}, 10-20 \mathrm{~cm})$ of the soil seed bank

- Seed density

- Species composition

- Functional types of species

- Structural parameters of target Fagus trees and their neighbors

- Diameter at breast height

- Tree height, height of crown basis and maximal crown extension

- Crown projection area

- Shannon-diversity of the neighborhood

- Crown stratification in the neighborhood of the target trees

- Intraspecific and interspecific competition intensity

- Radial increment patterns of stem growth

- Similarity of growth curves depending on neighborhood

- Reaction to pointer years

- Mean increment

- Mean sensitivity

- Long-term reaction to climatic parameters

- Correlation of standardized and raw increment values with precipitation and temperature in the last 80 years

- $\delta^{13} \mathrm{C}$ signature as proxy for stomatal conductance 
Neighborhood effects on radial increment were not only investigated as dependent on pure neighborhood diversity but also as response to selected tree species (Fagus sylvatica, Tilia spec., Fraxinus excelsior, Quercus spec., Acer pseudoplatanus).

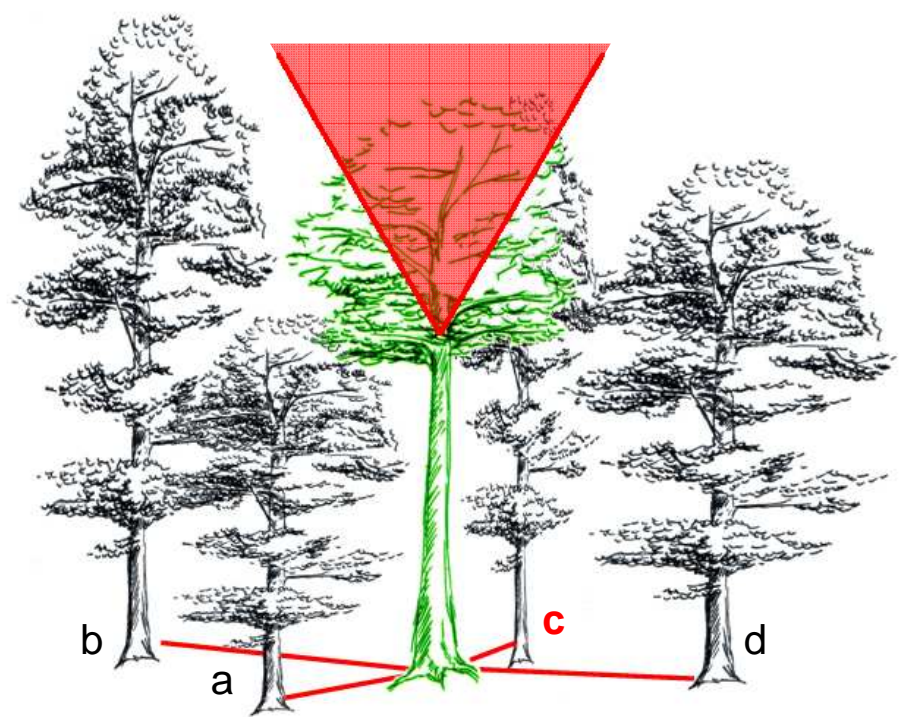

Fig. 4: Neighbors of Fagus target trees were considered as neighbors if a part of their crown was present in the "influence sphere" of this target tree, i.e. a cone with an angle of $60^{\circ}$ turned upside down with the apex being p ositioned at $60 \%$ of the target tree's height. In the shown constellation, only tree c would be considered as neighbor. The competition index (Cl) was calculated after Hegyi (1974) taking distance to the competitors and diameters at breast height of competitors and target tree into account.

\section{Study objectives and hypotheses}

The present study is part of the Research Training Group 1086, an interdisciplinary research project with 14 participating $\mathrm{PhD}$ students. The spatial focus on one research area enables cooperations between the subprojects. I was able to benefit from synergisms with other subprojects investigating, for example, recent vegetation, canopy transpiration and productivity. In my PhD thesis, I focused on diversity effects leaving long-term traces in the soil seed bank, radial increment series and $\delta^{13} \mathrm{C}$ signatures. I investigated direction, intensity, and asymmetry of interspecific competition in comparison to intraspecific neighborhood constellations. Tree species-specific traits were compared to pure diversity effects.

Among the central hypotheses of the Research Training Group 1086, three hypotheses were considered in my project:

- Increasing tree-species diversity correlates with higher diversity of other organisms, groups and guilds; the slope of this relationship differs significantly between the investigated groups.

- Increasing tree-species diversity enhances, due to niche complementarity, nutrient utilization, which results in reduced nutrient removal with soil leachate.

- Increasing tree-species diversity increases the temporal stability of carbon, water and nutrient turnover when natural disturbances occur.

In chapter 2, I tested the hypotheses that i) the actual herb-layer vegetation has a weak influence on the composition of the seed bank, ii) the species diversity of the seed bank increases with tree-layer 
diversity, and iii) tree species forming a more persistent litter layer reduce the number of germinating seeds.

Subsequently, I focused in chapter 3 on the hypothesis that the species identity of the neighbor trees and their functional traits can significantly influence growth rates and sensitivity of growth to environmental fluctuations, while the species diversity of the neighborhood is of no significance.

In Chapter 4, I investigated the hypotheses that i) $\delta^{13} \mathrm{C}$ signatures derived from annual tree rings are more closely correlated with climate parameters than tree ring series and that ii) there is a detectable effect of interspecific competition intensity on the level of $\delta^{13} \mathrm{C}$ signals in tree rings. 


\section{References}

Augusto, L., Ranger, J., Binkley, D. \& Rothe, A. (2002) Impact of several common tree species of European temperate forests on soil fertility. Annals of Forest Science, 59, 233-253.

Barbier, S., Gosselin, F. \& Balandier, P. (2008) Influence of tree species on understory vegetation diversity and mechanisms involved--A critical review for temperate and boreal forests. Forest Ecology and Management, 254, 1-15.

Bekker, R.M., Bakker, J.P., Grandin, U., Kalamees, R., Milberg, P., Poschlod, P., Thompson, K. \& Willems, J.H. (1998) Seed size, shape and vertical distribution in the soil: indicators of seed longevity. Functional Ecology, 12, 834-842.

Berger, T.W., Sun, B. \& Glatzel, G. (2004) Soil seed banks of pure spruce (Picea abies) and adjacent mixed species stands. Plant and Soil, 264, 53-67.

Bossuyt, B. \& Hermy, M. (2001) Influence of land use history on seed banks in European temperate forest ecosystems: a review. Ecography, 24, 225-238.

Brown, A. \& Oosterhuist, L. (1981) The role of buried seed in coppicewoods. Biological Conservation, 21, 19-38.

Canham, C.D., Finzi, A.C., Pacala, S.W. \& Burbank, D.H. (1994) Causes and consequences of resource heterogeneity in forests: interspecific variation in light transmission by canopy trees. Canadian Journal of Forest Research, 24, 337-349.

Canham, C.D., Papaik, M.J., Uriarte, M., McWilliams, W.H., Jenkins, J.C. \& Twery, M.J. (2006) Neighborhood analyses of canopy tree competition along environmental gradients in new England forests. Ecological Applications, 16, 540-554.

Cannell, M.G.R., Malcolm, D.C. \& Robertson , P.A. (Eds.). (1992) The ecology of mixed-species stands of trees. Blackwell Scientific Publications, Oxford.

Cottingham, K., Brown, B. \& Lennon, J. (2001) Biodiversity may regulate the temporal variability of ecological systems. Ecology Letters, 4, 72-85.

Cowles, H.C. (1911) The causes of vegetative cycles. Botanical Gazette, 51, 161.

Daubenmire, R.F. \& Daubenmire, J.B. (1968) Forest vegetation of eastern Washington and northern Idaho. Washington State University, (Pullman).

Decocq, G., Valentin, B., Toussaint, B., Hendoux, F., Saguez, R. \& Bardat, J. (2004) Soil seed bank composition and diversity in a managed temperate deciduous forest. Biodiversity and Conservation, 13, 2485-2509.

Egler, F.E. (1954) Vegetation science concepts I. Initial floristic composition, a factor in old-field vegetation development with 2 figs. Vegetatio, 4, 412-417.

Ellenberg, H. \& Leuschner, C. Vegetation Mitteleuropas mit den Alpen. Ulmer, Stuttgart.

Eriksson, O. (1995) Seedlings recruitment in deciduous forest herbs: the effects of litter, soil chemistry and seed bank. Flora, 190, 65-70.

Facelli, J. \& Pickett, S. (1991) Plant litter: Its dynamics and effects on plant community structure. The Botanical Review, 57, 1-32.

Frech, A. (2006) Walddynamik in Mischwäldern des Nationalparks Hainich - Untersuchung der Mechanismen und Prognose der Waldentwicklung. Berichte des Forschungszentrums Waldökosysteme (Reihe A), 196, 1-120. 
Garber, S.M. \& Maguire, D.A. (2004) Stand productivity and development in two mixed-species spacing trials in the Central Oregon Cascades. Forest Science, 50, 92-105.

Hegyi, F. (1974) A simulation model for managing jack-pine stands. Growth models for tree and stand simulation. (ed J. Fries), pp. 74-90. Royal College of Forestry, Stockholm.

Hein, S., Collet, C., Ammer, C., Le Goff, N., Skovsgaard, J.P. \& Savill, P. (2008) A review of growth and stand dynamics of Acer pseudoplatanus L.in Europe: implications for silviculture. Forestry, cpn043.

Joshi, J., Matthies, D. \& Schmid, B. (2000) Root hemiparasites and plant diversity in experimental grassland communities. Journal of Ecology, 88, 634-644.

Kelty, M.J. (1992) Comparative productivity of monocultures and mixed-species stands. The ecology and silviculture of mixed-species forests. (eds M.J. Kelty, B.C. Larson \& C.D. Oliver), Kluwer Academic Publishers.

Kerr, G., Nixon, C. \& Matthews, R.W. (1992) Silviculture and yield of mixed-species stands: the UK experience. The ecology of mixed-species stands of trees. (eds M.G.R. Cannell, D.C. Malcolm \& P.A. Robertson), pp. 35-51. Blackwell Scientific Publications, Oxford.

Knoke, T., Stimm, B., Ammer, C. \& Moog, M. (2005) Mixed forests reconsidered: A forest economics contribution on an ecological concept. Forest Ecology and Management, 213, 102-116.

Körner, C. (2005) An introduction to the functional diversity of temperate forest trees. Forest diversity and function - temperate and boreal systems. Ecological Studies. (eds M. Scherer-Lorenzen, C. Körner \& E. Schulze), pp. 13-37. Springer, Berlin.

Leck, M.A., Parker, V.T. \& Simpson, R.L. (Eds.). (2008) Seedling ecology and evolution. Cambridge University Press, Cambridge.

Légaré, S., Bergeron, Y. \& Paré, D. (2002) Influence of forest composition on understory cover in boreal mixed-wood forests of western Quebec. Silva Fennica, 36, 353-366.

Leuschner, C., Jungkunst, H.F. \& Fleck, S. (2009) Functional role of forest diversity: Pros and cons of synthetic stands and across-site comparisons in established forests. Basic and Applied Ecology, 10, 1-9.

Loreau, M., Naeem, S. \& Inchausti, P. (2002) Biodiversity and ecosystem functioning: synthesis and perspectives. Oxford University Press, New York.

Mölder, A., Bernhardt-Römermann, M. \& Schmidt, W. (2006) Forest ecosystem research in Hainich National Park (Thuringia): First results on flora and vegetation in stands with contrasting tree species diversity. Waldökologie-Online, 3, 83-99.

Mund, M. (2004) Carbon pools of European beech forests (Fagus sylvatica) under different silvicultural management. Universität Göttingen, Göttingen.

Nijs, I. \& Roy, J. (2000) How important are species richness, species evenness and interspecific differences to productivity? A mathematical model. Oikos, 88, 57-66.

Oliver, C.D. (1981) Forest development in North America following major disturbances. Forest Ecology and Management, 3, 153-168.

Oliver, C.D. \& Larson, B.C. (1990) Forest stand dynamics. McGraw-Hill, New York.

Piutti, E. \& Cescatti, A. (1997) A quantitative analysis of the interactions between climatic response and intraspecific competition in European beech. Canadian Journal of Forest Research, 27, 277-284 
Pretzsch, H. \& Schütze, G. (2009) Transgressive overyielding in mixed compared with pure stands of Norway spruce and European beech in Central Europe: evidence on stand level and explanation on individual tree level. European Journal of Forest Research, 128, 183-204.

Scherer-Lorenzen, M., Körner, C. \& Schulze, E. (Eds.). (2005) Forest diversity and function. temperate and boreal systems. Springer, Berlin.

Smith, T.M., Shugart, H.H. \& Woodward, F.I. (Eds.). (1997) Plant functional types: their relevance to ecosystem properties and global change. Cambridge University Press.

Telewski, F.W. \& Zeevaart, J.A.D. (2002) The 120-yr period for Dr. Beal's seed viability experiment. American Journal of Botany, 89, 1285-1288.

Thompson, K., Bakker, J.P. \& Bekker, R.M. (1997) The soil seed banks of North West Europe: methodology, density and longevity. Cambridge University Press, Cambridge.

Tilman, D. (1996) Biodiversity: Population versus ecosystem stability. Ecology, 77, 350-363.

Tilman, D. \& Downing, J.A. (1994) Biodiversity and stability in grasslands. Nature, 367, 363-365.

Tome, M. \& Burkhart, H.E. (1989) Distance-dependent competition measures for predicting growth of individual trees. Forest Science, 35, 816-831.

Underwood, A.J. \& Paine, R.T. (2007) Two views on ecological experimentation. Bulletin of the British Ecological Society, 38, 24-27.

Vacek, S. \& Lepš, J. (1996) Spatial dynamics of forest decline: The role of neighbouring trees. Journal of Vegetation Science, 7, 789-798.

Warr, S.J., Kent, M. \& Thompson, K. (1994) Seed bank composition and variability in five woodlands in south-west England. Journal of Biogeography, 21, 151-168.

Weber, P., Bugmann, H., Fonti, P. \& Rigling, A. (2008) Using a retrospective dynamic competition index to reconstruct forest succession. Forest Ecology and Management, 254, 96-106.

Wulf, M. (2003) Preference of plant species for woodlands with differing habitat continuities. Flora, 198, 444-460. 
Chapter 2

Structure and composition of the seed bank in monospecific and tree species-rich temperate broad-leaved forests

Published in: Forest Ecology and Management 257: 695-702 DOI: 10.1016/j.foreco.2008.09.052 
Full length article

\title{
Structure and composition of the seed bank in monospecific and tree species-rich temperate broad-leaved forests
}

\author{
Inga Schmidt ${ }^{a}$, Christoph Leuschner ${ }^{a, *}$, Andreas Mölder ${ }^{b}$, Wolfgang Schmidt ${ }^{c}$ \\ a Department of Plant Ecology and Ecosystems Research, Albrecht von Haller Institute for Plant Sciences, Georg-August-University of Göttingen, Untere Karspüle 2, \\ D-37073 Göttingen, Germany \\ b WWF Institute for Floodplain Ecology, Institute for Water and River Basin Management, University of Karlsruhe (TH), Josefstr. 1, D-76437 Rastatt, Germany \\ ${ }^{c}$ Department Silviculture and Forest Ecology of the Temperate Zones, Faculty of Forest Sciences and Forest Ecology, Georg-August-University of Göttingen, Büsgenweg 1 , \\ D-37077 Göttingen, Germany
}

A R TICLE INFO

\section{Article history:}

Received 17 July 2008

Received in revised form 27 September 2008

Accepted 29 September 2008

\section{Keywords:}

Stand age

Litter

Diaspores

Ecosystem engineer

\begin{abstract}
A B S TR A C T
How tree species diversity affects ecosystem functioning is a topic of intensive research. This study compares monospecific and species-rich broad-leaved forests under similar bedrock and climate conditions for the size and composition of their seed bank. We tested the hypotheses that (i) the actual herb-layer vegetation has an only weak influence on the composition of the seed bank, (ii) the species diversity of the seed bank increases with tree-layer diversity, and (iii) tree species forming a more persistent litter layer reduce the number of germinating seeds. The number of seeds and their species composition were investigated in soil cores taken from three soil depths $(0-5,5-10$ and $10-20 \mathrm{~cm} ; n=4$, with each 6 subsamples) in 9 study plots differing in tree species diversity ( 3 monospecific Fagus plots, 3 plots with Fagus, Fraximus and Tilia, and 3 plots with Fagus, Fraxinus, Tilia, Carpinus and Acer). Tree species diversity had a much stronger influence on the size and composition of the seed bank than herb-layer diversity or composition, the latter revealing only a low similarity to the cor responding seed bank. The number and species diversity of emerging seedlings decreased significantly with the amount of acidifying Fagus litter, but increased with litter mass of Tilia and other trees with nutrient-rich, rapidly decomposing litter. We conclude that tree species diversity does not influence the seed bank through effects on herb-layer composition, but mostly through differential disturbance histories of the stands and litter quality effects on germination and soil chemistry. From the contrasting effects of Fagus and Tilia leaf litter, it appears that effects of tree species identity are more relevant than influences of tree species diversity itself.
\end{abstract}

(c) 2008 Published by Elsevier B.V.

\section{Introduction}

There is a vital debate as to whether plant species diversity affects ecosystem functioning in natural and managed ecosystems (e.g., Kinzig et al., 2001; Loreau et al., 2002; Hector et al., 2007). For long, forestry has promoted the establishment of monospecific stands, thereby reducing the diversity of the tree layer in managed temperate and tropical forests. Only recently, increased efforts have been undertaken to extend the area of mixed species stands in forestry, in particular in Central Europe. However, it is not well understood how monospecific and species-rich stands differ with respect to herb-layer diversity and composition and seed bank properties (Godefroid et al., 2006). While a considerable number of studies has compared monospecific and two-species mixed stands

\footnotetext{
* Corresponding author. Tel.: +49551 395718; fax: +49551395701.
} E-mail address: cleusch@gwdg.de (C. Leuschner). regarding herb-layer vegetation (e.g., Lücke and Schmidt, 1997; Weckesser, 2003; Budde, 2006), the role of tree species richness in more diverse stands has only recently attracted attention (Mölder et al., 2006, 2008; Barbier et al., 2008).

This study compares a set of monospecific and species-rich broad-leaved stands on similar geologic bedrock with respect to the size and composition of their seed bank. Tree species diversity was low in pure beech stands (Fagus sylvatica L.) and increased to five to eight species per stand in nearby species-rich lindenmaple-hornbeam stands. Contrasts in tree species diversity and tree species identity could influence the seed bank in various ways, first through species influences on litter mass and quality, thereby influencing germination conditions and soil properties (Nordén, 1994; Augusto et al., 2003; Hagen-Thorn et al., 2004), second indirectly through effects on herb-layer structure, which is reported to be more diverse in forests with species-rich tree floras than in monospecific forests (McCune and Antos, 1981; Leuschner, 1999; Ingerpuu et al., 2003; Mölder et al., 2008). Thus, 
the diversity and identity of tree species could alter the seed source of the herb-layer vegetation by affecting its composition, or it might influence seed storage and germination conditions in the soil.

Many forest species have short-lived seeds and do not form a persistent seed bank (Fischer, 1987; Thompson et al., 1997; Devlaeminck et al., 2005). This is consistent with investigations on seed viability in forest soils reporting poor correspondence between species present in the actual flora and in the seed bank (Thompson and Grime, 1979; Staaf et al., 1987; Warr et al., 1994; Eriksson, 1995; Bossuyt and Hermy, 2001; Ebrecht and Schmidt, 2008). In many cases, the most abundant species in the herb-layer vegetation are absent from the seed bank, where species from nonforest habitats are often abundant (Fischer, 1987; Bossuyt et al., 2002).

We analyzed size and composition of the seed bank in nine forest stands with one, three or five dominant tree species and related seed bank structure to tree-species diversity, the composition of the existing actual herb layer, and soil properties. We tested the hypotheses that (i) the herb-layer composition has an only weak influence on the composition of the seed bank, (ii) the species diversity of the seed bank increases with tree-layer diversity, and (iii) tree species forming a more persistent litter layer reduce the number of germinating seeds.

\section{Study site}

The study was conducted in Hainich National Park (western Thuringia, Central Germany) close to the village of Weberstedt $\left(51^{\circ} 05^{\prime} 28^{\prime \prime} \mathrm{N}, 10^{\circ} 31^{\prime} 24^{\prime \prime} \mathrm{E}\right)$ at about $350 \mathrm{~m}$ elevation. Selection criteria of the study plots were comparability in terms of edaphic and climatic conditions, tree species richness and tree-laye composition, which we analyzed on three diversity levels (DL). For the purpose of characterizing tree-layer diversity, the ShannonWiener diversity index was calculated for each study plot based on the number of stems of all canopy-layer trees being present. Plots of DL1 consist nearly exclusively of $F$. sylvatica (European beech); DL2 harbours four dominant tree species: F. sylvatica, Fraximus excelsior (European ash), Tilia cordata and T. platyphyllos (littleleaved and large-leaved linden); DL3 contains seven major tree species: F. sylvatica, F, excelsior, T. cordata, T. platyphyllos, Carpinus betulus (hornbeam), Acer pseudoplatanus (sycamore maple), and $A$. platanoides (Norway maple).

For each diversity level, three representative plots (labelled with $\mathrm{a}, \mathrm{b}$ and $\mathrm{c}$ ) were chosen at a maximum distance to each other of $4.9 \mathrm{~km}$. The plots had a size of $50 \mathrm{~m}$ by $50 \mathrm{~m}$ and were fenced in 2005 to exclude disturbance by deer, wild boar and human trampling. In each plot, six $25 \mathrm{~m}^{2}$ subplots $(5 \mathrm{~m} \times 5 \mathrm{~m})$ were randomly selected along three 30-m-long transects that themselves were placed by random into the plots. All plots were chosen on eutrophic loess-derived soils with a profile depth of about $60 \mathrm{~cm}$, situated in level or gently sloping terrain on limestone (Triassic Upper Muschelkalk). According to the World Reference Base for Soil Resources (WRB), the soil type of the research sites is (stagnic) Luvisol. For the last 40 years, only single stems have been extracted from the stands, which are bearing deciduous forest for a period of at least 200 years. Thus, they represent ancient woodland with respect to stand continuity in the definition of Wulf (2003). The plots were selected in stand sections with a closed canopy and a more or less homogenous stand structure. Dominant forest communities are the Galio-Fagetum and the Hordelymo-Fagetum (beech forest communities on slightly acidic to basic soils), and the StellarioCarpinetum, a broad-leaved mixed forest rich in hornbeam, linden and ash (Mölder et al., 2006).

\section{Methods}

In March 2006, we extracted soil cores at 3 different depths (0$5,5-10$ and $10-20 \mathrm{~cm}$ ) using a soil monolith corer with a diameter of $8 \mathrm{~cm}$ (i.e. about $50.27 \mathrm{~cm}^{2}$ area). On each study plot, we took 4 mixed samples at random locations, which themselves consisted of 6 sub-samples (one per subplot). Herb-layer cover was estimated in percent on each subplot; tree saplings were not included in this estimate. In addition, herb species presence-absence data was gathered on the whole $2500 \mathrm{~m}^{2}$-plot. To cover the seasonal development of the herb-layer species, we recorded vegetation cover twice in April and July 2005 (Mölder et al., 2006).

The soil was passed through a sieve with a mesh size of $3 \mathrm{~mm}$ to remove coarse particles and for homogenizing the samples. Each sample was evenly spread on a bed of sterilized sand and exposed in a glasshouse. Soil moisture was daily checked and water added if necessary. Temperature was kept constant on a level of about $20^{\circ} \mathrm{C}$. The larger samples from the 10 to $20 \mathrm{~cm}$ horizon were transferred to two beds for ensuring comparable germination conditions of all samples. We also established a control treatment with sterilized sand in order to quantify the error introduced by seeds that may have reached the seed beds during the experiment. Until the end of February 2007, i.e. for a period of 12 months, we controlled the beds regularly by counting and removing identified seedlings.

Juncus effusus, which was with up to 2669 seeds $\mathrm{m}^{-2}$ by far the most abundant species germinating in the soil samples, was excluded from all subsequent analyses that refer to seedling numbers. This procedure seemed to be justified as long as qualitative analyses of seed bank composition are aimed at (see Fischer, 1987; Bossuyt et al., 2002). Similarly, tree seedlings (such as Tilia sp., Salix sp., C. betulus, Betula pendula) were also excluded from the analyses.

To quantify the proportion of characteristic woodland species in the seed bank, all species were assigned to different habitat types and groups of plant communities for which they are known to be characteristic following the synecological species classification systems of Ellenberg et al. (2001) and Schmidt et al. (2003). Nomenclature of vascular plants follows Wisskirchen and Haeupler (1998). The source for the classification into dispersal types is Frank and Klotz (1990). We will refer to the plants of the existing herb layer as "actual vegetation", which is contrasted with the corresponding seed bank.

Tree species composition of the leaf litter fallen in autumn 2005 and its chemical properties were analyzed by Brauns et al. (in preparation). Soil $\mathrm{pH}$ measured in $\mathrm{KCl}$ was determined in subsamples of the extracted soil monoliths. Mean tree age was determined for dominant trees (class 1 and 2 according to Kraft, 1884) by count of annual tree rings based on analyses with a LINTAB 5 measuring table and TSAP-software (Rinn, 2003). If the pith of the trunk was not hit by coring, we measured the distance of the core centre to the intersection of the medullary rays and calculated the number of rings with a mean width of $1 \mathrm{~mm}$. Data on earthworm densities in the topsoil was gathered in October 2006 to obtain a measure of bioturbation (N. Fahrenholz, personal communication; Cesarz et al., 2007).

\section{Statistical analyses}

For statistical analyses, we used the software R(Version 2.7.1, R Development Core Team, 2008) with the packages vegan, npmc, fpc, and ade4. We used a nonparametric multiple comparison test after Steel (Munzel and Hothorn, 2001) for comparisons between diversity levels and horizons. Relative distributions, such as species associations (sociological species groups), were analysed 
with a $\chi^{2}$-test of goodness of fit. Datasets of seed bank and actual vegetation were clustered using Bray-Curtis dissimilarity between the plots as a criterion and applying the average linkage method. We computed the average maximum Jaccard coefficient over resampled datasets $(10,000$ bootstrap replications) to assess the stability of the obtained clusters. Linear regression analyses were applied to quantify the influence of stand and soil properties on seed bank characteristics. Unless otherwise stated, a significance level of $p<0.05$ was used throughout.

\section{Results}

\subsection{Tree species diversity and seed bank composition}

In total, we recorded 65 species of higher plants in the seed bank of the 9 investigated plots, including 12 graminoids, 45 forbs, and 8 woody species. Species richness of the germinated seedlings increased with increasing tree-layer diversity as did species richness of the actual herb-layer vegetation (Fig. 1). However, species richness of the actual herb-layer vegetation showed a greater increase with tree diversity than species richness of the seedlings. The density of germinated seeds ranged from $298 \mathrm{~m}^{-2}$ in the beech-dominated DL1 plots to 3606 seeds $\mathrm{m}^{-2}$ in the more diverse DL3 plots. J. effusus with an extraordinarily high seedling number was excluded from these calculations (for seedling numbers see Table 1 ).

\subsection{Similarity between seed bank and actual vegetation}

According to the cluster analysis of relative species abundance in the actual vegetation and the seed bank, the species composition aboveground and in the seed bank in general was much more similar than the species composition among the three tree diversity levels (Fig. 2). In contrast to the herb-layer

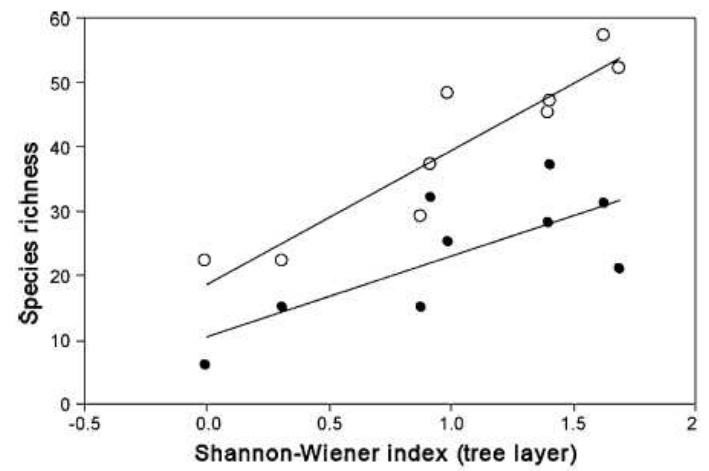

Fig. 1. Relationship between species richness of the herb-layer vegetation open circles, referring to $2500 \mathrm{~m}^{2}$ ) or of the seed bank (filled circles) and the Shannon-Wiener Index of the tree layer (calculated from the number of stems of the species present).

vegetation, the seed bank data did not reveal the groups of plots, which were located closer to each other and thus were more similar in their actual vegetation than the more distant ones. The seed bank composition mostly reflected the classification of the stands according to tree-layer diversity. If comparing the similarity of the 9 plots with respect to the actual herb-layer vegetation or seed bank composition, it is evident that vegetation relevés are more similar to each other than the composition of the bank of emerged seedlings in the plots. With respect to the seed bank, pure beech stands (DL1) are clearly distinguishable from mixed stands (DL2 and DL3). The number of species present in the actual vegetation and also occurring as emerged seedlings was significantly higher in DL2 (mean: 6 species) and DL3 (mean: 7 species) than in DL1 (mean: 1 species). On the contrary,

Table 1

Stand structural and environmental characteristics of the nine study plots.

\begin{tabular}{|c|c|c|c|c|c|c|c|c|c|}
\hline Plot no. & DL1a & DL1b & DL1c & DL2a & DL2b & DL2C & DL3a & DL3b & DL3C \\
\hline Forest community & HF & GF & GF & $\mathrm{HF}$ & SC & GF & SC & SC & SC \\
\hline \multicolumn{10}{|l|}{ Age of canopy trees [year] } \\
\hline Median & 107 & 145 & 193 & 79 & 98 & 79 & 117 & 90 & 93 \\
\hline Minimum & 96 & 130 & 157 & 48 & 45 & 59 & 86 & 50 & 40 \\
\hline Maximum & 125 & 162 & 202 & 116 & 132 & 122 & 150 & 197 & 198 \\
\hline Tree-layer diversity $\left(\mathrm{TH}^{\prime}\right)$ & 0.3 & 0.9 & 0.0 & 1.4 & 1.0 & 0.9 & 1.7 & 1.6 & 1.4 \\
\hline Herb-layer diversity $\left(\mathrm{HH}^{\prime}\right)$ & 0.2 & 0.5 & 0.4 & 0.8 & 1.1 & 0.4 & 1.7 & 1.5 & 1.0 \\
\hline Species richness of actual vegetation & 22 & 29 & 22 & 45 & 48 & 37 & 52 & 57 & 47 \\
\hline Species richness of seed bank & 15 & 15 & 6 & 28 & 25 & 32 & 21 & 31 & 37 \\
\hline Seed density [seeds $\left.\mathrm{m}^{-2}\right]$ & 298 & 319 & 298 & 2164 & 1144 & 1185 & 1567 & 3606 & 3258 \\
\hline \multicolumn{10}{|l|}{ Litter quality ${ }^{a}$} \\
\hline Beech litter [\%] & 92.8 & 88.1 & 99.7 & 48.1 & 73.6 & 57.1 & 9.0 & 12.8 & 34.0 \\
\hline Linden litter [\%] & 1.5 & 0.2 & 0.0 & 17.9 & 3.4 & 13.0 & 46.9 & 38.4 & 14.0 \\
\hline $\mathrm{C} / \mathrm{N}$ ratio of litter & 56.9 & 67.7 & 59.2 & 54.7 & 56.6 & 59.5 & 48.9 & 53.5 & 44.6 \\
\hline Litter layer depth $[\mathrm{cm}]^{\mathrm{b}}$ & 3.9 & 4.0 & 5.8 & 2.0 & 2.4 & 2.9 & 2.3 & 1.8 & 3.0 \\
\hline Soil $\mathrm{pH}$ in $\mathrm{KCl}$ & 3.8 & 3.7 & 3.6 & 4.6 & 4.7 & 4.4 & 5.1 & 5.2 & 5.5 \\
\hline Earthworm density $\left[\mathrm{m}^{-2}\right]^{c}$ & 162 & 74 & 9 & 92 & 92 & 236 & 180 & 223 & 171 \\
\hline Beech in root mass $[\%]^{d}$ & 97.7 & 96.8 & 100.0 & 61.8 & 59.1 & 36.1 & 2.6 & 16.5 & 18.6 \\
\hline \multicolumn{10}{|l|}{ Relative radiance $[\%]^{e}$} \\
\hline Mean & 1.0 & No data & No data & 0.9 & 0.8 & 0.8 & 1.5 & 1.4 & 0.7 \\
\hline $\mathrm{CV}^{\mathrm{f}}$ & 18.7 & No data & No data & 23.1 & 22.5 & 26.1 & 27.8 & 22.0 & 17.7 \\
\hline
\end{tabular}

HF: Hordelymo-Fagetum lathyretosum (beech forest), GF: Galio-odorati Fagetum (beech forest), SC: Stellario-Carpinetum stachyetosum (oak-hornbeam forest),

Information on litter quality has been provided by M. Brauns.

b Thickness of upper organic layer Of/Oh and the litter layer $\mathrm{L}$

c Earthworm density data by N. Fahrenholz.

d Beech root mass after Meinen et al. (in preparation).

e PPFD on the forest floor in percent of incident flux density (after Mölder et al., 2008)

$f$ Coefficient of variation. 
698

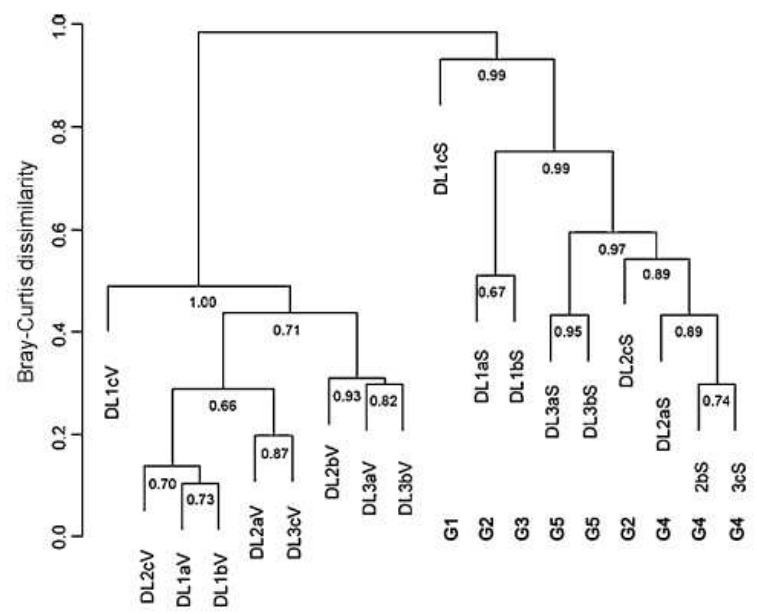

ธ ช ช

Fig. 2. Cluster dendrogram showing dissimilarities between actual vegetation (plots DL1aV to DL3cV located at the left branch of the diagram) and seed bank (DL1aS to DL3cS, right branch) and between the nine study plots. V stands for relevés of actual herb-layer vegetation, $\mathrm{S}$ for the composition of the corresponding seed bank. Clustering was based on Bray-Curtis dissimi larity and average linkage method used. Bootstrapping (10,000 resampling runs) allowed calculation of clusterwise Jaccard bootstrap means (numbers on cluster nodes) indicating cluster stability. Plots have been assigned to groups ( $G 1$ to $G 5$ ) according to their location in the research area.

quantitative analysis taking seedling numbers into account did not reveal a distinct pattern: the seedling numbers of the species from the actual vegetation varied considerably in the seed bank of the three diversity levels (DL1: 0-6 seedlings, DL2: 14-76 seedlings, DL3: 14-66 seedlings).

\subsection{Sociological groups represented in the seed bank}

With regard to species numbers in the seed bank, species from Central European broad-leaved forest communities (QuercoFagetea) seemed to be underrepresented in the monospecific DL1 stands. Typical forest species with germinating seeds were for example Carex sylvatica, Moehringia trinervia, Poa nemoralis, and Scrophularia nodosa. They were accompanied by an even greater number of species characteristics for mesic and wet grasslands (Molinio-Arrhenateretea; e.g., Poa pratensis, Deschampsia cespitosa, and Trifolium repens), or for forest clearings (Epilobietea angustifolii; e.g., Epilobium angustifolium, Hypericum hirsutum) (Fig. 3). In the more diverse mixed stands (DL2 and DL3), species from the Querco-Fagetea were the dominant group and of even greater importance than in the DL1 stands. Nevertheless, most sociological groups listed in Fig. 3 were present in the seed bank of all three diversity levels. However, the three forest diversity levels differed significantly with respect to the relative importance of the sociological species groups being present in the seed bank $(\alpha=0.001)$

If seedling numbers and not species numbers are compared among the diversity levels, the distribution of forest species showed clear trends with increasing tree-layer diversity (Fig. 4). Seedlings of species characteristic of closed forest outweighed species that mostly occur in more open habitats in the DL1 plots, but did not so in the mixed DL2 and DL3 plots. The more species-rich the tree layer, the smaller was the importance of seedlings of the strict forest species in the seed bank, while the abundance of species from clearings or forest margins increased.

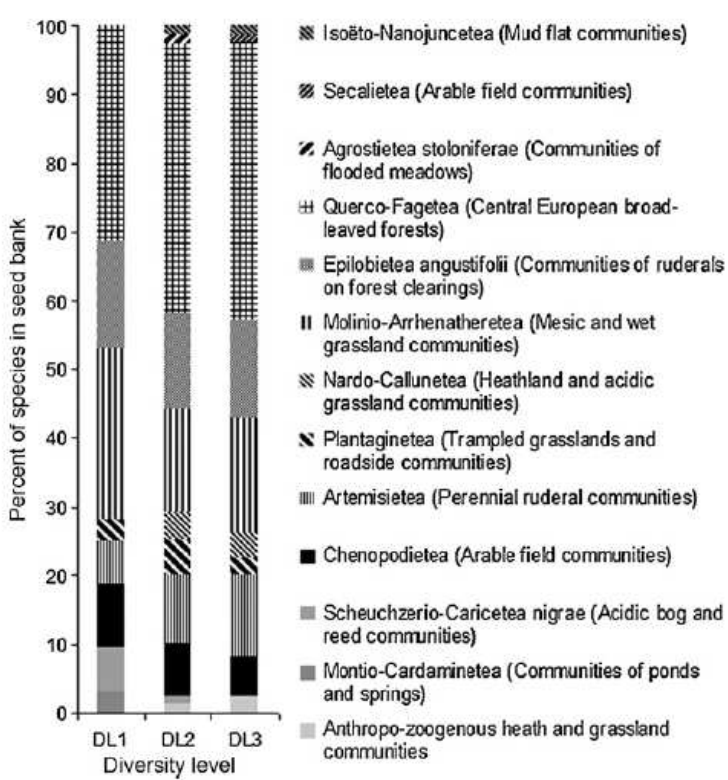

Fig. 3. Composition of the seed bank in terms of the sociological behaviour of the species (affiliation to 13 vegetation classes according to Ellenberg et al., 2001). $N=3$ plots per diversity level. Species numbers have not been weighted by seedling numbers.

\subsection{Plant functional types in the seed bank}

With respect to the number of germinated seeds, we observed a shift in the dispersal modes toward a greater relative importance of anemochory (e.g., Epilobium sp., Hypericum sp.) but a reduced abundance of autochory (e.g., Cardamine flexuosa, Carex sp.) in the seed bank of the DL3 plots as compared to the DL1 and DL2 plots. Myrmecochorous (e.g., Luzula pilosa) and epizoochorous species (e.g., Juncus articulatus, D. cespitosa) were more abundant in the species-poor DL1 stands than elsewhere (Fig. 5).

The mean seed longevity index according to Bekker et al. (1998) decreased with increasing tree species diversity with the

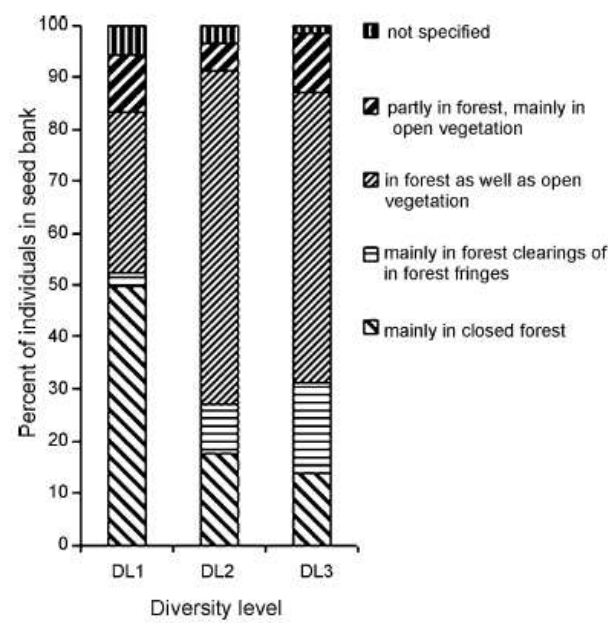

Fig. 4. Composition of the seed bank in the plots of the three diversity levels according to preference for forest habitats (species assignment after Schmidt et al 2003). Species are weighted by seedling numbers. 


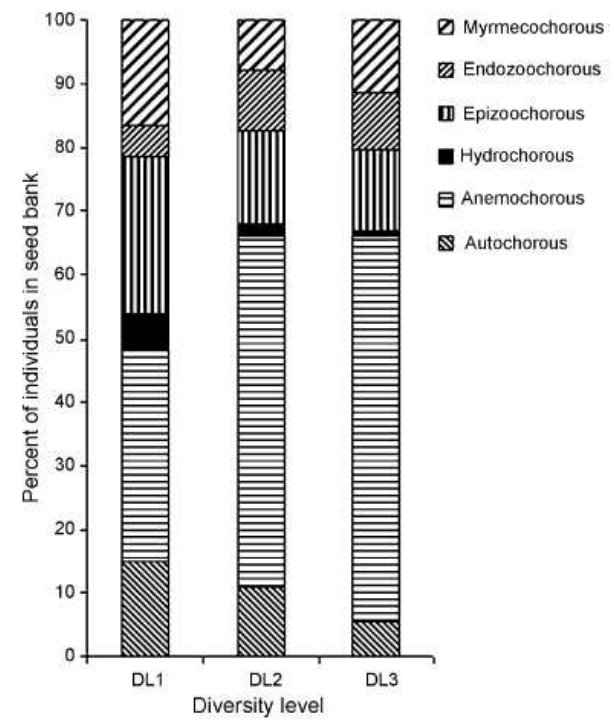

Fig. 5. Composition of the seed bank in the three diversity levels according to dispersal type.

difference between DL1 (0.63) and DL3 plots (0.51) being significant. Index values close to zero stand for a (strictly) transient seed bank, whereas a value close to 1 indicates a bank of persistent seeds. Hence, the species in the tree species-poor stands have, on average, a more persistent seed bank than those from the highly diverse mixed stands.

Graminoids, which are by far the largest group of the monocotyledons, were most numerous in the seed bank of the tree species-poor stands. Their dominance diminishes with increasing tree species diversity. The seeds of graminoids showed a more distinct vertical stratification in the soil than the seeds of the dicotyledonous species (Fig. 6).

The percentage of seeds of hemicryptophytes increased with tree species diversity in the stands (DL1: 71, DL2: 76, DL3: 89\%), whereas the percentage of therophyte seeds decreased (DL1: 10, DL2: 4, DL3: 3). All life forms occurred with germinating seedlings in the three diversity levels except for hemicryptophytes growing as lianas (Vicia sepium and Lathyrus pratensis), which only occurred in the most diverse stands.

\subsection{Qualitative changes in the seed bank composition between species-poor and rich stands}

Of the overall 60 species occurring in the seed bank of the study plots (tree species excluded), only 16 species were present in all three diversity levels (e.g., $L$. pilosa, C. sylvatica, S. nodosa, Viola reichenbachiana). Two species exclusively occurred in DL1 (Prunus spinosa agg. and C. flexuosa), while five species were restricted to the DL1 and DL2 plots (Chenopodium album, J. articulatus, Sagina procumbens, $T$. repens, Veronica montana). Eleven species solely occurred in the species-rich DL3 plots, including Myosotis arvensis, Festuca heterophylla, and Lamium purpureum. Among the species, that occurred in the species-rich plots but were absent in the species-poor beech plots, were mostly light-demanding species with a preference for subneutral to basic soils. The median light indicator value after Ellenberg et al. (2001) of those species, which additionally were present as seedlings in the DL2 and DL3 plots, was 6 and 7 as compared to 5.5 for the species only occurring in DL1. The median indicator value for soil $\mathrm{pH}$ (reaction) increased
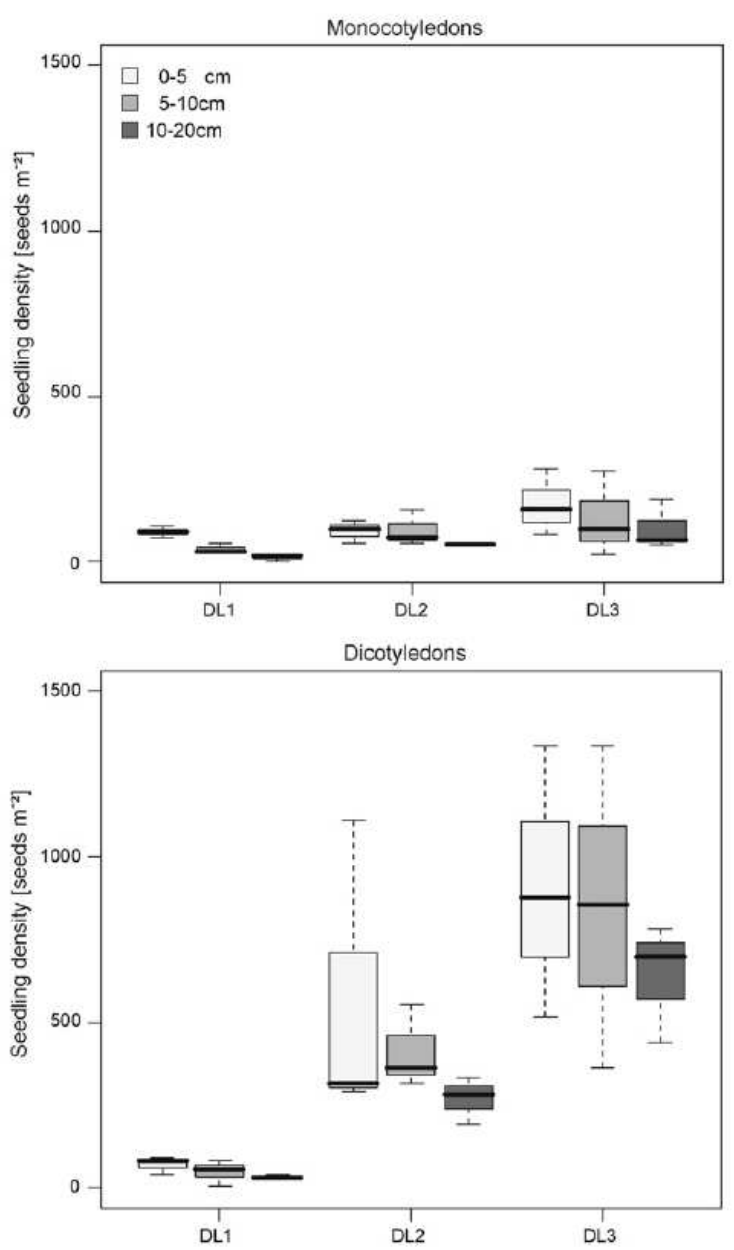

Fig. 6. Average number of emerged seedlings per sample taken in three soil depths in the each three plots of the three diversity levels. Box-whisker plots with median (bold line), lower and upper quartiles (box), and smallest and largest observations (whiskers). Juncus effusus has been excluded from the calculations.

from 6 to 6.5 and 7 in the species added to the species pool between DL1, DL2 and DL3, respectively.

Whereas the DL1 plots were dominated by species growing in moderate shade, plants additionally emerging with seedlings in DL3 generally were much more light demanding (Table 1).

\subsection{Factors influencing size and composition of the seed bank}

Correlation analyses between seed bank properties in the nine stands and various abiotic and biotic variables revealed that the total number of germinated seeds (excluding $J$. effusus and tree species) was positively related to soil $\mathrm{pH}$, tree-layer diversity and the relative proportion of linden in the annual leaf litter fall, while a negative relationship appeared with the proportion of beech litter, litter $\mathrm{C} / \mathrm{N}$ ratio, the total amount of leaf litter fall, and the proportion of beech in the fine root mass. Tree age and diversity of the herb-layer vegetation had only a weak influence on seedling numbers, which disappeared when only the number of seedlings of true forest species was considered (Table 2). Factors influencing the number of true forest species with viable seeds in the soil seed bank were soil pH and earthworm density (positive) and tree age 
Table 2

Spearman correlation coefficients for the relationships between various seed bank properties and abiotic and biotic variables.

\begin{tabular}{|c|c|c|c|c|c|c|}
\hline & & $\begin{array}{l}\text { Seedling density } \\
{\left[\text { seeds } \mathrm{m}^{-2}\right]^{a}}\end{array}$ & $\begin{array}{l}\text { Total species } \\
\text { number }\end{array}$ & $\begin{array}{l}\text { Seedling density } \\
\text { of forest species }\end{array}$ & $\begin{array}{l}\text { Number of } \\
\text { forest species }\end{array}$ & $\begin{array}{l}\text { Bray-Curtis dissimilarity of } \\
\text { seed bank and actual vegetation }\end{array}$ \\
\hline Age of canopy trees ${ }^{b}$ & $\begin{array}{l}r \\
p\end{array}$ & $\begin{array}{r}-0.68 \\
0.045\end{array}$ & $\begin{array}{r}-0.82 \\
0.007\end{array}$ & $\begin{array}{l}-0.60 \\
0.097\end{array}$ & $\begin{array}{c}-\mathbf{0 . 8 9} \\
0.001\end{array}$ & $>0.100$ \\
\hline Tree-layer diversity $\left(\mathrm{TH}^{\prime}\right)$ & $\begin{array}{l}r \\
p\end{array}$ & $\begin{array}{l}\mathbf{0 . 8 8} \\
0.002\end{array}$ & $\begin{array}{l}0.61 \\
0.081\end{array}$ & $\begin{array}{l}\mathbf{0 . 8 2} \\
0.011\end{array}$ & $\begin{array}{l}0.62 \\
0.073\end{array}$ & $\begin{array}{c}-0.85 \\
0.006\end{array}$ \\
\hline Herb-layer diversity $\left(\mathrm{HH}^{\prime}\right)$ & $\begin{array}{l}r \\
p\end{array}$ & $\begin{array}{l}\mathbf{0 . 6 7} \\
0.049\end{array}$ & $>0.100$ & $\begin{array}{l}0.67 \\
0.059\end{array}$ & $>0.100$ & $\begin{array}{l}-0.60 \\
0.097\end{array}$ \\
\hline Litter quality & & & & & & \\
\hline Beech litter [\%] & $\begin{array}{l}r \\
p\end{array}$ & $\begin{array}{c}-\mathbf{0 . 9 0} \\
0.001\end{array}$ & $\begin{array}{c}-0.66 \\
0.053\end{array}$ & $\begin{array}{c}-0.80 \\
0.014\end{array}$ & $\begin{array}{c}-0.68 \\
0.046\end{array}$ & $\begin{array}{l}0.90 \\
0.002\end{array}$ \\
\hline Linden litter [\%] & $\begin{array}{l}r \\
p\end{array}$ & $\begin{array}{l}0.85 \\
0.003\end{array}$ & $\begin{array}{l}0.61 \\
0.081\end{array}$ & $\begin{array}{l}\mathbf{0 . 7 8} \\
0.017\end{array}$ & $\begin{array}{l}\mathbf{0 . 7 2} \\
0.029\end{array}$ & $\begin{array}{c}-0.92 \\
0.001\end{array}$ \\
\hline $\mathrm{C} / \mathrm{N}$ ratio & $\begin{array}{l}r \\
p\end{array}$ & $\begin{array}{c}-0.73 \\
0.026\end{array}$ & $>0.100$ & $\begin{array}{c}-0.88 \\
0.003\end{array}$ & $>0.100$ & $>0.100$ \\
\hline Litter layer depth $[\mathrm{cm}]^{\mathrm{c}}$ & $\begin{array}{l}r \\
p\end{array}$ & $\begin{array}{c}-0.79 \\
0.012\end{array}$ & $>0.100$ & $\begin{array}{r}-0.70 \\
0.043\end{array}$ & $\begin{array}{c}-\mathbf{0 . 7 5} \\
0.019\end{array}$ & $\begin{array}{l}0.80 \\
0.014\end{array}$ \\
\hline Soil $\mathrm{pH}$ in $\mathrm{KCl}$ & $\begin{array}{l}r \\
p\end{array}$ & $\begin{array}{l}0.87 \\
0.002\end{array}$ & $\begin{array}{l}\mathbf{0 . 7 6} \\
0.017\end{array}$ & $\begin{array}{l}0.90 \\
0.002\end{array}$ & $\begin{array}{l}\mathbf{0 . 7 2} \\
0.029\end{array}$ & $\begin{array}{c}-0.60 \\
0.097\end{array}$ \\
\hline Earthworm density $\left[\mathrm{m}^{-2}\right]$ & $\begin{array}{l}r \\
p\end{array}$ & $\begin{array}{l}0.60 \\
0.090\end{array}$ & $\begin{array}{l}\mathbf{0 . 7 1} \\
0.034\end{array}$ & $>0.100$ & $\begin{array}{l}\mathbf{0 . 7 5} \\
0.020\end{array}$ & $\begin{array}{c}-0.59 \\
0.092\end{array}$ \\
\hline Beech roots [\% of living root biomass] & $\begin{array}{l}r \\
p\end{array}$ & $\begin{array}{r}-0.82 \\
0.008\end{array}$ & $\begin{array}{r}-\mathbf{0 . 6 8} \\
0.045\end{array}$ & $\begin{array}{c}-\mathbf{0 . 7 2} \\
0.037\end{array}$ & $\begin{array}{c}-0.62 \\
0.073\end{array}$ & $\begin{array}{l}\mathbf{0 . 7 8} \\
0.017\end{array}$ \\
\hline
\end{tabular}

a Seedling density refers to germinated seeds without Juncus effusus. We calculated $\mathrm{TH}^{\prime}$ for all stems of the tree layer in the plots with different tree-diversity levels. HH' was calculated for the actual vegetation of the sampled subplots. We used Spearman's correlation coefficient $(r)$ test for two-sided significance of $r$.

${ }^{b}$ Mean age of dominant trees in the canopy (median)

c Thickness of upper organic layer Of/Oh and the litter layer L.

and proportion of beech fine roots (negative). Earthworm density was used as a surrogate variable for bioturbation. The dissimilarity between the composition of seed bank and corresponding actual herb-layer vegetation increased with the quantity of overall leaf litter fall, and the proportion of beech in leaf litter and fine root mass, but decreased with tree-layer diversity and an increasing proportion of linden in leaf litter mass.

In general, the tested variables mostly showed a stronger correlation with seed density than with the number of species with germinated seeds. Exceptions from this observation are mean tree age and earthworm density. Moreover, the effect of tree-layer diversity was much greater than that of herb-layer diversity.

\section{Discussion}

\subsection{Correspondence between actual vegetation and seed bank composition}

The majority of studies on viable seeds in forest soils reported a poor correspondence between species present in the actual flora and in the seed bank (Thompson and Grime, 1979; Eriksson, 1995; Bossuyt and Hermy, 2001; Ebrecht and Schmidt, 2008). A similar result was obtained in our study on 9 broad-leaved old-growth forest stands where the composition of the herb-layer vegetation and its diversity had an only weak influence on the size and diversity of the corresponding seed bank, thus supporting hypothesis (i). A cluster analysis revealed that the species composition of the actual vegetation was more similar among different plots than between actual vegetation and the corresponding seed bank of that plot. While species composition of the actual vegetation allows a grouping primarily based on geographic distance between the plots, thus reflecting topographic and competition-induced gradients in the forest area, the seed bank composition rather followed the distinction between tree-species poor DL1 and tree species-rich DL2 and DL3 plots. In fact, tree-layer diversity or tree identity had a much stronger influence on seed bank size and composition than had herb-layer diversity. This is in agreement with results obtained by, for example, Decocq et al. (2004), Bossuyt et al. (2002), and Ebrecht and Schmidt (2008) thus supporting our second hypothesis. The poor correspondence between herb-layer composition and seed bank structure rules out the possibility that tree-layer diversity or tree species identity acted on the seed bank indirectly via herb-layer composition as is suggested by the strong correlation found between tree- and herblayer diversity in our stands. Nevertheless, we conducted an observational study, which can never proof relationships but only reveals correlations. The discrepancy between herb-layer and seed bank composition has been explained by the absence of light demanding, early-successional species in the herb layer of closed, old-growth forests, which produce persistent seed banks (Fischer, 1987; Warr et al., 1994; Ebrecht and Schmidt, 2008). In contrast, late-successional shade-tolerant herb-layer species (e.g., Anemone nemorosa, Mercurialis perennis), which dominate closed old-growth forests, typically produce transient or short-lived seed banks that disappear after several years or a few decades (Fischer, 1987). At a first glance, our data show an opposite pattern with a more persistent seed bank in species-poor and older DL1 stands if species values are taken into account. However, this pattern is not confirmed when seedling numbers are considered.

\subsection{Variables affecting tree species diversity and seed bank}

More likely explanations of the positive relation between treespecies diversity and seed bank diversity in our study are differences between species-poor and species-rich stands in stand history, differences in microclimate, or tree species effects on litter layer and pH status of the mineral soil. In the Hainich area, as in many other Central European forests, tree-species richness is largely a result of past forest management. Different ownership and management goals have created in the Hainich forest a small- 
scale mosaic of stands differing in tree-species diversity with monospecific beech stands growing in close neighborhood of species-rich forests with ash, linden, hornbeam, maple and beech. The practice of selective cutting (Plenterwald) or coppicing with standards (Mittelwald), which foster species-rich stands, most likely was associated with a higher disturbance regime for the past $150-200$ years than the management of beech in age-class forests.

This could be one explanation of the fact that the seed bank of DL2 and DL3 plots is not only richer in species, but also in the number of germinated seeds. In these stands with their specific management history, herbaceous species characteristic for disturbance are occurring more frequently in the herb layer than in pure beech stands (Mölder et al., 2006). In the light of the different forest management practices in DL1, DL2 and DL3 stands, the sequence from the tree species-rich stands with a large and diverse seed bank (DL3) to the pure beech stands with a much poorer seed bank resembles in a certain sense a succession towards more stable, less disturbed forests. Ebrecht and Schmidt (2008) and Van Calster et al. (2008) found a similar trend with higher species numbers in managed or recently disturbed forests in comparison to unmanaged forests or stands with longer management cycles. In early-successional forests, seed banks typically contain more disturbance-tolerant species, the seed bank is to a greater extent persistent and it is often more similar to the actual herb-layer vegetation than it is in late-successional stages such as mature beech forests (Beatty, 1991; Landenberger, 1999). Late-successional forests, which are often ancient woodlands with long continuity as well, typically have lower seed densities and the percentage of species with autochorous or myrmecochorous species is higher (Warr et al., 1994; Beatti and Culver, 1981; Pickett and McDonnell, 1989 after Nakagoshi, 1984). These patterns are confirmed by our data characterizing the tree-species poor beech stands (DL1) as less disturbed forests as compared to the species-rich DL2 and DL3 stands.

6.3. Relationships between tree-species diversity or identity and the seed bank

A factor that may change with increasing tree-species diversity in forests is microclimate, in particular radiation transmission to the forest floor, which could influence herb-layer composition and seed bank (Barbier et al., 2008; Mölder et al., 2008). However, mean PAR transmissivity ranged between 0.7 and $1.5 \%$ of incident flux density in all stands with no clear change being visible between the monospecific and the species-rich stands.

More influential on the seed bank seems to be the effect exerted by certain tree species and tree species combinations on litter quality and decomposition rate. Leaf litter can have contrasting effects on the seed bank and germination success of forest plants. It may provide a favourable storage medium of seeds if it remains moist throughout the summer. On the contrary, thick layers of slowly decaying leaf litter are known to hamper seedling emergence of many forest floor species, while it can favour the offspring of those species that are able to penetrate through the litter layer, because they suffer from less competition by other species (Sydes and Grime, 1981; Facelli and Pickett, 1991). In the Hainich forest, tree species with rather slow litter decay such as beech co-occur with species like linden, hornbeam and ash with a rapid decomposition (Nordén, 1994; van Oijen et al., 2005). Our data show a clear negative correlation between seed bank size and litter layer thickness, which makes a causal explanation of seed bank paucity in the DL1 stands by the thick beech litter layer very likely. On the other hand, linden (and ash or hornbeam) litter increases the germination success of many species, at least of the typical forest species.
However, not only litter mass and its persistence on the floor may influence seed bank composition and seed germination, but litter chemistry as well. First, a more nitrogen- and base-rich litter favours earthworm biomass and diversity in the soil (Reich et al., 2005; Cesarz et al., 2007), promoting seed transport via bioturbation to lower soil horizons. The high numbers of dicotyledon seeds in 10-20 cm depth in the DL3 stands must be a consequence of the relatively high earthworm density in these soils. Second, more base-rich litter results in less soil acidification, which affects herblayer composition as the seed source and therewith also the seed bank (Mölder et al., 2008). Various authors reported larger seed banks in base-rich forest soils than in base-poor soils (Brown and Oosterhuis, 1981; Staaf et al., 1987). Even though the topsoil pH $(\mathrm{KCl})$ increased in our sample from 3.6 to 3.8 in the DL1 stands to 5.1-5.5 in the DL3 stands, which can be related to tree species effects (Mölder et al., 2008), it must remain unclear whether the concomitant increase in seed bank size and diversity is a causal relationship or more coincidence. A certain influence of tree age (which acts in a similar way as stand continuity) or other environmental factors cannot be ruled out in a correlative approach as adopted in this study.

Even if the importance of the controlling factors is difficult to quantify, it is safe to conclude that tree-layer diversity does not influence the seed bank through effects on the herb-layer composition, but mostly through differential disturbance histories, and litter quality effects on germination and soil chemistry.

\section{Conclusion}

Tree species diversity had a much stronger influence on the size and composition of the seed bank than herb-layer diversity or composition, the latter revealing only a low similarity to the corresponding seed bank. The number and species diversity of emerging seedlings decreased significantly with the amount of acidifying Fagus litter, but increased with litter mass of Tilia and other trees with nutrient-rich, rapidly decomposing litter. We conclude that tree species diversity does not influence the seed bank through effects on herb-layer composition, but mostly through differential disturbance histories of the stands and litter quality effects on germination and soil chemistry. From the contrasting litter effects of Tilia and the ecosystem engineer Fagus, it appears that effects of tree species identity are more relevant than influences of tree species diversity itself.

\section{Acknowledgements}

We thank Heiko Rubbert for help with soil sampling and Markus Bernhardt-Römermann for discussions. The study is funded by the German Research Council (DFG) within the Research Training Group 1086. Many colleagues from the Research Training Group supported our studies with data and comments, especially Nadine Fahrenholz, Mascha Jacob and Catharina Meinen.

\section{References}

Augusto, L, Dupouey, J., Ranger, J., 2003. Effects of tree species on understory vegetation and environmental conditions in temperate forests. Annals of Forest Science 60, 823-831.

Barbier, S., Gosselin, F., Balandier, P., 2008. Influence of tree species on understory vegetation diversity and mechanisms involved-a critical review for temperate and boreal forests. Forest Ecology and Management 254, 1-15.

Beatti, A.J., Culver, D.C., 1981. The guild of Myrmecochores in the herbaceous flora of West Virginia forests. Ecology 62, 107-115.

Beatty, S.W., 1991. Colonization dynamics in a mosaic landscape; the buried seed pool. Journal of Biogeography 19, 553-563.

Bekker, R.M., Bakker, J.P., Grandin, U., Kalamees, R., Milberg, P., Poschlod, P., Thompson, K., Willems, J.H., 1998. Seed size, shape and vertical distribution
Then Thompson, K., Willems, J.H., 1998. Seed size, shape and vertical distribution
in the soil: indicators of seed longevity. Functional Ecology 12, 834-842. 
Bossuyt, B., Hermy, M., 2001. Influence of land use history on seed banks in European temperate forest ecosystems: a review. Ecography 24, 225-238.

Bossuyt, B., Heyn, M., Hermy, M., 2002. Seed bank and vegetation composition of forest stands of varying age in central Belgium: consequences for regeneration of ancient forest vegetation. Plant Ecology 162, 33-48.

Brown, A.H.F., Oosterhuis, L., 1981. The role of buried seed in coppice woods. Biological Conservation 21, 19-38.

Budde, S., 2006. Auswirkungen des Douglasienanbaus auf die Bodenvegetation im nordwestdeutschen Tiefland. Cuvillier Verlag, Göttingen.

Cesarz, S., Fahrenholz, N., Migge-Kleian, S., Platner, C., Schaefer, M., 2007. Earthworm communities in relation to tree diversity in deciduous forest. European Journal of Soil Biology 43, S61-S67.

Decocq, G., Valentin, B., Toussaint, B., Hendoux, F., Saguez, R., Bardat, J., 2004. Soil seed bank composition and diversity in a managed temperate deciduous forest. Biodiversity and Conservation 13, 2485-2509.

Devlaeminck, R., Bossuyt, B., Hermy, M., 2005. Inflow of seeds through the forest edge: evidence from seed bank and vegetation patterns. Plant Ecology 176, 1-17.

Ebrecht, L., Schmidt, W., 2008. Bedeutung der Bodensamenbank und des Diasporentransports durch Forstmaschinen für die Entwicklung der Vegetation auf Rückegassen. Forstarchiv 79, 91-105.

Ellenberg, H., Weber, H.E., Düll, R., Wirth, V., Werner, W., 2001. Zeigerwerte von Pflanzen in Mitteleuropa. Scripta Geobotanica 18, 1-264.

Eriksson, O., 1995. Seedling recruitment in deciduous forest herbs: the effects of litter, soil chemistry and seed bank. Flora 190, 65-70.

Facelli, J.M., Pickett, S.T.A., 1991. Plant litter: its dynamics and effects on plant community structure. The Botanical Review $57,1-32$

Fischer, A., 1987. Untersuchungen zur Populationsdynamik am Beginn von Sekundärsukzessionen. Die Bedeutung von Samenbank und Samenniederschlag auf die Wiederbesiedlung vegetationsfreier Flächen in Wald- und Grünlandgedie Wiederbesiedlung vegetationsfreier Flächen in

Frank, D., Klotz, S., 1990. Biologisch-ökologische Datenzur Flora der DDR. Wissenschaftliche Beiträge der Martin-Luther-Universität Halle-Wittenberg 32, 1-167.

Godefroid, S., Phartyal, S.S., Koedam, N., 2006. Depth distribution and composition of seed banks under different tree layers in a managed temperate fores ecosystem. Acta Oecologica 29, 283-292.

Hagen-Thorn, A., Callesen, I., Armolaitis, K., Nihlgard, B., 2004. The impact of six European tree species on the chemistry of mineral topsoil in forest plantations on former agricultural land. Forest Ecology and Management 195, 373-384.

Hector, A., Joshi, J., Scherer-Lorenzen, M., Schmid, B., Spehn, E.M., Wacker, L. Weilenmann, M., Bazeley-White, E., Beierkuhnlein, C., Caldeira, M.C., Dimitrakopoulos, P.G., Finn, J.A., Huss-Danell, K., Jumpponen, A., Leadley, P.W., Loreau, M., Mulder, C.P.H., Neßhöver, C., Palmborg, C., Read, D.J., Siamantziouras, A. S.D. Terry, A.C., Troumbis, AY., 2007. Biodiversity and ecosystem functioning: reconciling the results of experimental and observational studies. Functional reconciling the results
Ecology $21,998-1002$.

Ingerpuu, N., Vellak, K., Liira, J., Pärtel, M., 2003. Relationships between species richness patterns in deciduous forests at the north Estonian limestone escarpment. Journal of Vegetation Science 14, 773-780.

Kinzig, A.P., Pacala, S.W., Tilman, D., 2001. The functional consequences of biodiversity: empirical progress and theoretical extensions. Monographs in Population Biology 33, 1-365.

Kraft, G., 1884. Beiträge zur Lehre von den Durchforstungen. Schlagstellungen und Lichtungshieben. Klindworth's Verlag, Hannover:

Landenberger, C.E., 1999. Mixed-mesophytic forest understory communities and edge effect: the role of canopy gaps in edge composition and structure. PhD Thesis. College of Agriculture, Forestry, and Consumer Sciences, Morgantown, West Virginia, Division of Forestry. 1-173.

Leuschner, C., 1999. Zur Abhängigkeit der Baum- und Krautschicht mitteleuropäischer Waldgesellschaften von der Nährstoffversorgung des Bodens. Berichte päischer Waldgesellschaften von der Nährstoffiver
der Reinhold-Tüxen-Gesellschaft $11,109-131$

Loreau, M., Naeem, S., Inchausti, P. (Eds.), 2002. Biodiversity and Ecosystem Functioning. University Press, Oxford.
Lücke, K., Schmidt, W., 1997. Vegetation und Standortsverhältnisse in BuchenFichten-Mischbeständen des Sollings. Forstarchiv 68, 135-143.

McCune, B., Antos, J.A., 1981. Correlations between forest layers in the Swan Valley Montana. Ecology 62, 1196-1204.

Mölder, A., Bernhardt-Römermann, M., Schmidt, W., 2006. Forest ecosystem research in Hainich National Park (Thuringia): first results on flora and vegetation in stands with contrasting tree species diversity. Waldökologie-Online 3 , 83-99.

Mölder, A, Bernhardt-Römermann, M., Schmidt, W., 2008. Herb-layer diversity in deciduous forests: raised by tree richness or beaten by beech? Forest Ecology and Management 256, 272-281.

Munzel, U., Hothorn, LA., 2001. A unified approach to simultaneous rank test procedures in the unbalanced one-way layout. Biometrical Journal 43,553-569.

procedures in the unbalanced one-way layout. Biometrical Journal $43,553-569$.
Nakagoshi, N., 1984. Buried viable seed populations in forest communities on the Hiba Mountains, southwestern Japan. Journal of Science of Hiroshima UniverHiba Mountains, southwestern Jap
sity Series B, Division $219,1-56$.

Nordén, U., 1994. Influence of broad-leaved tree species on pH and organic matter content of forest topsoils in Scania, South Sweden. Scandinavian Journal of Forest Research 9, 1-8.

Pickett, S.T.A., McDonnell, M.J., 1989. Seed bank dynamics in temperate deciduous forest. In: Leck, M.A. Parker, V.T., Simpson, R.L. (Eds.), Ecology of Soil Seed Banks. Academic Press, London, pp. 123-147.

R Development Core Team, 2008. R: A Language and Environment for Statistical Computing. R Foundation for Statistical Computing, Vienna, Austria, http:/ www.R-project.org.

Reich, P.B., Oleksyn, J., Modrzynski, J., Mrozinski, P., Hobbie, S.E., Eissenstat, D.M. Chorover, J., Chadwick, O.A., Hale, C.M., Tjoelker, M.G., 2005. Linking litter calcium, earthworms and soil properties: a common garden test with 14 tree calcium, earthworms and soil propertice
species. Ecology Letters $8,811-818$.

Rinn, F., 2003. TSAP-Win. Time Series Analysis and Presentation for Dendrochronology and Related Applications, Version 0.59 for Microsoft Windows. Rinn Tech, Heidelberg, Germany, pp. 1-110.

Schmidt, M., Ewald, J., Fischer, A, von Oheimb, G., Kriebitzsch, W.-U., Schmidt, W. Ellenberg, H., 2003. Liste der typischen Waldgefäßpflanzen Deutschlands Mitteilung der Bundesforschungsanstalt für Forst- und Holzwirtschaft 212 , 1-34 (Appendix).

Staaf, H., Jonsson, M., Olsén, L.-G., 1987. Buried germinative seeds in mature beech forests with different herbaceous vegetation and soil types. Holarctic Ecology $10,268-277$.

Sydes, C., Grime, J.P., 1981. Effect of tree leaf litter on herbaceous vegetation in deciduous woodland. II-An experimental investigation. Journal of Ecology 69 , 249-262.

Thompson, K., Grime, J.P., 1979. Seasonal variation in the seed banks of herbaceous species in ten contrasting habitats. Journal of Ecology 67, 893-921.

Thompson, K., Bakker, J., Bekker, R., 1997. The Soil Seed Banks of North West Europe: Methodology, Density and Longevity. Cambridge University Press, Cambridge. Van Calster, H., Chevalier, R., Van Wyngene, B., Archaux, F., Verheyen, K., Hermy, M 2008. Long-term seed bank dynamics in a temperate forest under conversion from coppice-with-standards to high forest management. Applied Vegetation Science $11,252-260$

van Oijen, D., Feijen, M., Hommel, P.W.F.M., den Ouden, J., van der Waal, B.H.C. 2005. Effects of tree species composition on within-forest distribution of understorey species. Applied Vegetation Science 8, 155-166.

Warr, S.J., Kent, M., Thompson, K., 1994. Seed bank composition and variability in five woodlands in south-west England. Journal of Biogeography 21, 151-168.

Weckesser, M., 2003. Die Bodenvegetation von Buchen-Fichten-Mischbeständen im Solling-Struktur, Diversität und Stoffhaushalt. PhD Thesis. University of Göttingen, Cuvilier, Göttingen.

Wisskirchen, R., Haeupler, H., 1998. Standardliste der Farn- und Blütenpflanzen Deutschlands. Ulmer, Stuttgart.

Wulf, M., 2003. Preference of plant species for woodlands with differing habitat continuities. Flora $198,444-460$. 
Chapter 3

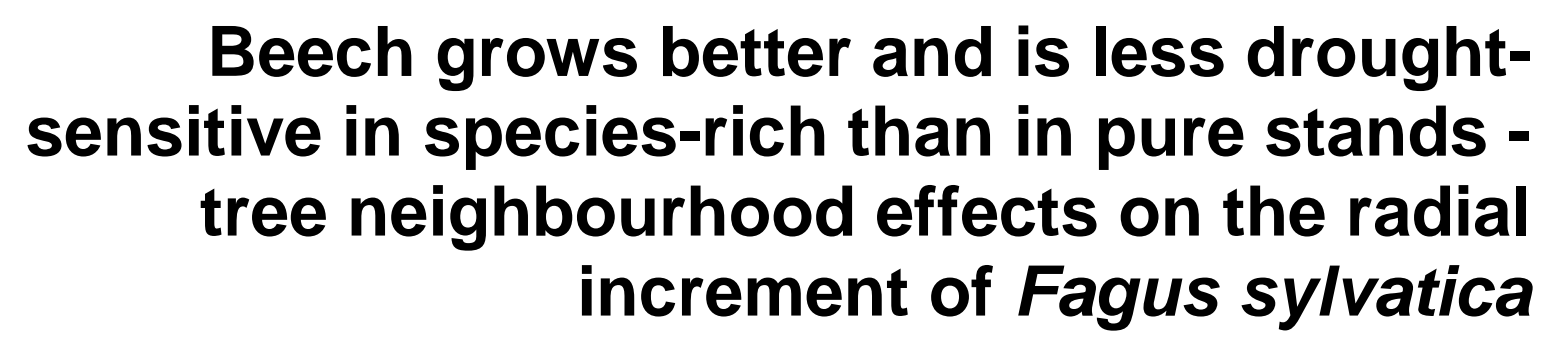




\section{Beech grows better and is less drought-sensitive in species-rich than in pure stands - Tree neighbourhood effects on the radial increment of Fagus sylvatica}

Inga Mölder \& Christoph Leuschner

\section{Abstract}

In a natural species-rich temperate forest, we analyzed the tree ring chronologies of 152 Fagus sylvatica L. target trees from tree neighbourhoods varying in species composition and tree diversity. We tested the hypothesis that the species identity of the neighbour trees and their functional traits can significantly influence radial stem increment and environmental sensitivity of growth of the target trees while the species diversity of the neighbourhood is of no significance. We measured mean increment and analyzed the growth response to, and recovery from, selected stress events (negative pointer years), and investigated the influence of an important edaphic variable, soil clay content, on these growth parameters.

Fagus trees in a neighbourhood with more than $30 \%$ of the canopy's "influence sphere" occupied by allospecific trees had a significantly higher mean stem increment, a lower increment sensitivity to environmental fluctuation and a smaller growth depression in the 1976 drought as compared to beech trees entirely surrounded by conspecific trees. However, the neighbourhood constellation had only a weak or no influence on the 1986-2005 ring chronologies, i.e. long-term growth response types to environmental fluctuation, while soil clay content was an important factor.

In contrast to expectation, mean annual increment of Fagus did not decrease with an increase in Hegyi's competition index $\mathrm{Cl}$ which measures crowding by the trees in the neighbourhood. Treespecies diversity in the neighbourhood (as expressed by Shannon's H') had no influence on mean stem growth rate while it lowered the growth sensitivity to environmental fluctuation. We found evidence for a significant influence of the neighbours' species identity on beech growth: Positive effects on mean increment and a reduced ring series sensitivity of Fagus were found for Tilia, Fraxinus and Acer neighbourhoods, but not for Quercus neighbourhoods.

We conclude that the neighbourhood of a tree can significantly influence its mean stem increment and growth sensitivity to environmental fluctuation in temperate mixed forests with the effect partly depending on the species identity of the neighbours.

Key-words: dendrochronology, dendroecology, interspecific competition, negative pointer year, stem increment, temperate broad-leaved forest, tree diversity 


\section{Introduction}

Plants growing in dense stands interact with their neighbours in multiple ways with either positive or negative consequences for the partners. Positive interactions are those in which one or more neighbours facilitate the existence of a target individual by increasing its fitness, for example by improving the nutrient and water supply in the direct proximity of this plant (Brooker et al. 2008). Negative interactions reduce the fitness of one or more partners of the interaction, primarily through the consumption of a growth-limiting resource, or through direct chemical or mechanical interactions with a negative outcome for the fitness.

While plant-plant interactions have been studied in detail in a multitude of natural and synthetic herbaceous plant communities, much less is known about the mechanisms of tree-tree interactions and their consequences in mature forests. Since more than a century, foresters have conducted growth trials investigating density effects on the yield of monospecific plantations of conifers and broad-leaved tree species (e.g., Seebach 1845; Bohdanecký 1926; Assmann 1970; Plauborg 2004). These studies have greatly improved our understanding of the nature of intraspecific competition among woody plants and its dependence on stem density, canopy structural properties, and nutrient and water availability (Piutti \& Cescatti 1997; Chen et al. 2003; Gouveia \& Freitas 2008). Interspecific interactions in mixed tree plantations have also received considerable attention with a focus on total wood harvest in comparison to monocultures of the respective species, testing for overyielding effects in species mixtures (Man \& Lieffers 1999; Piotto et al. 2003; Pretzsch \& Schütze 2009). Many of the competition studies in mixed stands referred to even-aged cultures with a regular planting scheme where stem densities and tree neighbourhood constellations were defined.

Much less is known about tree interactions in natural mixed forests where stem density, tree age and tree size vary across the stand and trees grow in highly variable, often stochastic, neighbourhood constellations (Canham et al. 2006, DeClerck et al. 2006). Demographic and modelling studies in the context of forest dynamics research documented the growth reduction in individuals of inferior species in temperate and boreal mixed forests as a consequence of long-term asymmetric competition (e.g., Bonn 1998; Yoshida \& Kamitani 2000; Canham et al. 2006; Getzin et al. 2006), but these studies mostly did not relate the outcome of interspecific competition to a specified competitor (but see Canham et al. 2006). While competition with neighbours generally leads to negative effects on one or all neighbours in terms of vitality and/or productivity, the consequences of competition can be assessed with a negative or positive outcome when a target tree is compared in its growth in either allospecific or conspecific neighbourhood. Whereas competition research in natural mixed forests has produced many documents on the outcome of asymmetric competition, it is still at its infancy in defining the underlying mechanisms of interspecific interactions, in particular neighbourhood effects on the growth and survival of individual members of the community.

Tree ring analysis represents a promising tool for analyzing growth responses of target trees to defined neighbourhood constellations and for comparing different species in their neighbour effect on a target species. In theory, trends in radial stem increment can be the consequence of the tree's ontogenetic development, of alterations in tree vitality, of climatic or edaphic change, or of neighbourhood effects on carbon gain and growth, the latter being either negative or positive. 
Several authors have reported growth depressions in target trees that were inferior competitors in mixed stands with a dominant species, for example Quercus petraea L. or robur (Matt.) Liebl. in mixture with Fagus sylvatica L. in various stands in Central Germany (Bonn 1998), or Pinus sylvestris L. in mixture with F. sylvatica and Abies alba Mill. in Poland (Podlaski 2002).

In this paper, we report about a dendrochronological study in a species-rich temperate broadleaved forest where one species (Fagus sylvatica L., European beech), under certain conditions, grows better in species mixture than in monospecific stands, i.e. profits in relative terms in its productivity from the presence of allospecific neighbours compared to a conspecific neighbourhood. By analyzing tree ring chronologies of 152 beech target trees from tree neighbourhoods varying in species composition and tree diversity, we attempted to separate species identity and diversity effects on stem growth responses of Fagus. The effect of an important edaphic characteristic (soil clay content) on growth was also considered. We tested the hypothesis that the species identity of the neighbour trees and their functional traits can significantly influence growth rates and environmental sensitivity of growth of a target tree while the species diversity of the neighbourhood is of no significance. We measured not only mean increment, but analyzed the growth response to selected stress events (negative pointer years) and its subsequent recovery to obtain a measure of growth sensitivity and growth resilience of Fagus in defined neighbourhood constellations. This investigation is part of the Hainich Tree Diversity Matrix Study which analyzes the functional role of tree diversity in a temperate mixed forest (Leuschner et al. 2009).

\section{Material and methods}

\section{STUDY SITES}

The study was conducted in the broad-leaved forests of Hainich National Park (western Thuringia, Central Germany) close to the village of Weberstedt (5105'28'N, 1031'24"E) at about $350 \mathrm{~m}$ elevation where 12 study plots were chosen. Dominant forest communities are the Galio-Fagetum and the Hordelymo-Fagetum associations, i.e. beech forests on slightly acidic to basic soils, and the Stellario-Carpinetum association, a broad-leaved mixed forest rich in hornbeam, linden and ash (Mölder et al., 2008). Dominant tree species were Fagus sylvatica L. (European beech), Fraxinus excelsior L. (European ash) and Tilia cordata Mill. (little-leaved linden), while T. platyphyllos Scop. (large-leaved linden), Carpinus betulus L. (European hornbeam) and Acer pseudoplatanus L. (Sycamore maple) occurred at lower densities.

The plots were chosen at a maximum distance to each other of $4.9 \mathrm{~km}$ on eutrophic loessderived soils with a profile depth of about $60 \mathrm{~cm}$, situated in level or gently sloping terrain on limestone (Triassic Upper Muschelkalk). According to the World Reference Base for Soil Resources (WRB), the soil type of the research sites is (stagnic) Luvisol. For the last 40 years, only single stems have been extracted from the stands, which are forests with a continuity of at least 200 years (Schmidt et al. 2009). Thus, they represent ancient woodland in the definition of Wulf (2003). All 12 plots were selected in stand sections with a closed canopy and a more or less homogenous stand structure. 
For guaranteeing sufficient comparability with respect to edaphic conditions, we conducted soil chemical and physical surveys on all prospective study sites prior to plot installation. The study area is characterized by an annual mean temperature of $7.5^{\circ} \mathrm{C}$ and about $590 \mathrm{~mm}$ of precipitation per year (1973-2004, Deutscher Wetterdienst Offenbach, Germany). The 12 stands represent a gradient with increasing tree-species diversity from pure Fagus forests to stands with 5 and more tree species present, which coincides with a decreasing importance of beech in the canopy. Four stands are monospecific Fagus stands, four are mixed Fagus-Tilia-Fraxinus stands (48 to $73 \%$ beech stems), and another four stands are species-rich Fagus-Tilia-Fraxinus-Carpinus-Acer stands (beech contribution $<42 \%$ of the stems). Each study plot had a size of about 4 ha (200 m x $200 \mathrm{~m}$ ) and comprised a central $50 \mathrm{~m} \times 50 \mathrm{~m}$ plot (which is identical to the plots defined by Leuschner et al. 2009) and the immediate surrounding stand area.

\section{SELECTION OF TREE INDIVIDUALS}

For investigating radial increment of beech in its dependence on variable stem neighbourhoods, we selected 152 adult Fagus trees in the 12 plots according to pre-defined criteria in summer 2006. All target beech trees were part of the upper canopy and had a diameter at breast height (dbh) of 40 to $60 \mathrm{~cm}$. The direct neighbourhood of these trees was characterized by recording the species identity, $\mathrm{dbh}$, height and relative position of those trees $>7 \mathrm{~cm}$ dbh which grew directly adjacent to the beech target tree. These tree groups usually consisted of three to maximal nine trees per selected beech tree and covered stand areas of about 100 to $600 \mathrm{~m}^{2}$ size. The following measurements were conducted in winter 2006/2007 in the 152 tree clusters with the aim to characterize the neighbourhood of the beech target trees qualitatively and quantitatively: besides dbh, tree height and species composition, we quantified the crown dimensions of the neighbours by 8-point crown projections. In summer 2007, hemispheric photos, the latter being were taken with a digital camera equipped with a fisheye lens, thus providing information on canopy dimensions, gap fraction and canopy openness in the neighbourhood of the central beech tree. To calculate canopy openness, we used the software Gap Light Analyzer 2.0 (Simon Fraser University, British Columbia, Canada \& Institute of Ecosystem Studies, New York, USA) and restricted the canopy perspective to an opening angle of $30^{\circ}$ from the zenith which is in agreement with the protocol for analyzing tree competition in forests applied by Pretzsch (1995). We calculated the coefficient of variation (CV) of tree height in the tree clusters in order to express canopy heterogeneity and the degree of overlap of different canopy strata. To estimate the intensity of competition in the tree clusters, we calculated the competition index $\mathrm{Cl}$ after Hegyi (1974) for all those trees in the neighbourhood of the target beech tree that were present with part of their crown in the "influence sphere" of this tree, i.e. a cone with an angle of $60^{\circ}$ turned up side down with the apex being positioned at $60 \%$ of the target tree's height. The more trees being present in this cone and the smaller the distance to the target tree, the higher is the competition index:

$$
C I_{i}=\sum_{j=1}^{n} \frac{d_{j} / d_{i}}{D_{i s t_{i j}}}
$$


where $d_{i}$ is the diameter at breast height of the target tree $i(\mathrm{~cm}) ; d_{j}$ is the diameter at breast height of the competitor $\mathrm{j}(\mathrm{cm})$; and Dist $\mathrm{tij}_{\mathrm{j}}$ is the distance between target tree and competitor $(\mathrm{m})$.

We further expressed the tree diversity of the clusters with the Shannon diversity index $\left(\mathrm{H}^{\prime}\right)$ and grouped the clusters according to the importance of Fagus and non-Fagus trees in the neighbourhood (group A: all neighbours are Fagus: Fagus100, group B: 70 to $99 \%$ of the competition index value is contributed by Fagus-Fagus interactions: Fagus70-99, group C: less than $70 \%$ of the $\mathrm{Cl}$ value is due to Fagus-Fagus interaction but more than $30 \%$ are due to allospecific interactions: Fagus $<70$ ). The A group refers to entirely conspecific neighbourhoods (Fagus-Fagus), while B and C represent neighbourhood constellations with an increasing proportion of non-beech individuals (i.e. Tilia, Fraxinus, Quercus and Acer) surrounding the beech target tree. Thus, the group B contains clusters where beech-beech canopy contacts are dominant while allospecific neighbourhoods are significant. Group $C$ refers to tree groups where beech is surrounded by a number of other species while the importance of conspecific trees is only moderate or low. Only very few clusters existed $(n=6)$ where beech was exclusively surrounded by other species representing an exclusively interspecific neighbourhood of Fagus. These few cases were included in group $C$ (Fagus $<70$ ). Thus, the neighbourhood classes $A, B$ and $C$ represented a sequence from an exclusively conspecific neighbourhood to tree groupings where beech was exposed, to a large extent, to an allospecific neighbourhood. Each of the three groups contained about 50 tree clusters (A: 56, B: 49, C: 47).

In our neighbourhood analysis, we treated the closely related species Tilia cordata and T. platyphyllos, and Quercus robur and Q. petraea as one species to simplify the analysis. Half of the Fagus trees $(n=77)$ were selected in forest patches with a soil somewhat richer in clay (23 to $42 \%)$, the other half $(n=72)$ on clay-poorer soil $(14$ to $22 \%)$ because variation in clay content is the most influential edaphic gradient in the study area. Three target trees were excluded from those analyses which took clay content into account due to the absence of information on soil clay content. Since we detected that clay content was a major environmental factor in the data set, we conducted most analyses separately for the clay-rich and clay-poor sub-samples.

\section{STEM CORING AND DENDROCHRONOLOGICAL ANALYSES}

In summer 2006, all 152 Fagus target trees were cored at $1.3 \mathrm{~m}$ height ( $5 \mathrm{~mm}$ corer) on that side of the trunk which showed lowest influence of wood tension or compression. To meet the conservation regulations of the Hainich National Park, each tree was cored only once. We focused the dendrochronological analyses on growth comparisons within a given core to minimize possible bias due to missing replicate cores in the tree individuals.

The surface of the cores was recut with a razor blade and rubbed with titanium dioxide to increase the visibility of the tree rings before ring analysis. Annual tree ring width was measured to the nearest $0.01 \mathrm{~mm}$ using a LINTAB-5 dendrochronological measuring table (Rinn Tech, Heidelberg, Germany) and TSAP-Software (TSAP-Win Version 0.59 for Microsoft Windows, Rinn Tech, Heidelberg, Germany). In a pre-analysis, we searched for unrecognizable or questionable rings in the cores in order to reconsider them during cross-dating. As quality criteria, we considered the t-value 
(Baillie \& Pilcher 1973; Hollstein 1980), the co-linearity of increment (Gleichläufigkeit, Eckstein \& Bauch 1969), and the cross-dating index (Grissino-Mayer \& Kaennel Dobbertin 2003). Cross-dating of a chronology was accepted as being reliable, when it reached a minimum t-value of 3.5 (Baillie \& Pilcher 1973; Hollstein 1980), a minimum co-linearity of $70 \%$ for a 50 -year overlap (Eckstein \& Bauch 1969; Frech 2006), and a minimum cross-dating-index (CDI) > 20 (Müller 2007).

The dendrochronological analysis of the 152 cores focused on (i) average annual increment in the past two to four decades, (ii) the climate sensitivity of annual radial growth, (iii) the extent of growth depression (or growth increase) in selected negative (or positive) pointer years, and (iv) the extent of growth recovery subsequent to a negative pointer year. Average annual increment was calculated for the 20-year period 1986-2005. Mean increment sensitivity as a measure for growth variation in response to mainly climatic influences was calculated according to Fritts (2001). Pointer years were identified by comparing annual increment of a given stand chronology with 11-year moving averages of the stand chronology. Years with an increment of only 70 percent or less than the moving average were considered as negative pointer years (Bonn 1998). Even though the years 2003/2004 do not meet this criterion, they were considered here in the context of negative pointer years as well, because the summer drought 2003 was very severe in Central Europe (Ciais et al. 2005). The year 1999 represented a positive pointer year with an annual increment at least 30\% higher than the moving average in most of the stands. We compared the growth response to 4 pointer years $(1976,1992$, 1999, 2003/2004) among the different beech target trees by relating the increment in the pointer year to the year prior to the growth reduction (in the case of 2003/2004, the drought occurred late in summer 2003 and the growth reduction was for most trees visible after a lag phase only in 2004; thus, we related the 2004 increment to 2003). Increment recovery after a growth depression was quantified by relating the cumulative growth in the 14 or 30 years subsequent to the drought event to the increment in the year (or the 5 years) prior to drought when average increment occurred. This procedure is feasible because beech increment typically requires a couple of years or even decades to recover from a severe drought (i.e. negative pointer year). In our analysis, the negative pointer years 1976 and 1992 were used to analyze the rapidity of increment recovery in the different beech individuals. In these analyses, we only included those beech individuals in the calculations which showed an increment reduction in 1976 or 1992, and revealed a complete growth recovery until 2005.

\section{STATISTICAL ANALYSES}

The analysis of the dendrochronological time series included several steps. We applied different highpass filters in order to remove the age trends of growth but to keep variation up to 20 years wavelength. Satisfactory results were achieved with the following approach. The series were first logarithmically transformed, then filtered by a dynamically weighted moving average. The length of the moving average varied according to the variance of the ring width. On average, the filter width was defined as 40 years (variable Kern-Filter; Leuschner et al. 2002; Riemer 1994). In this manner, volatile intervals with a large variance, such as abrupt changes of growth rate, were filtered more intensively than smooth intervals that show little variance. 
Subsequently, we conducted a clustering of the ring series (average linkage) using the program HiCLASS developed by Riemer (1994) in order to group beech trees with similar growth trends and interannual increment variability in the time interval 1981-2005. Six main clusters with each at least 7 Fagus trees could be distinguished in the complete sample representing trees with a common growth response (clusters with less than 7 trees are not presented). The frequency of occurrence of these response types in the different beech neighbourhood categories was investigated with contingency tables. We calculated expected values, compared them to observed frequencies and used the squared residuals for evaluating over- and under-representation.

Generalized linear models were calculated to test for significant influences of apparent competition intensity (as estimated by the competition index $\mathrm{Cl}$ ) in the neighbourhood of the Fagus tree on a number of radial increment response variables of the target tree. Significant differences in absolute stem increment and increment response parameters among beech trees of different neighbourhood categories were detected with a non-parametric multiple comparison procedure after Hothorn et al. (2008), implemented for Tukey-contrasts. Significance was assumed for two-sided pvalues $<0.05$; in certain tables, differences on a less conservative significance level $p<0.1$ are also indicated. For two-sample comparisons, the $\mathrm{p}$-value was permuted. In order to take gradients of neighbourhood diversity and competition into account, we used generalized linear models. Model selection started from a model including all the independent variables considered and the dependent variable being log-transformed. We proceeded with backward removal of less significant variables one by one until all the variables remaining in the model contributed with a $p<0.10$ to the fitting of the model. For these statistical analyses, we used the software $\mathrm{R}$ (version 2.8.1, R Foundation for Statistical Computing, Vienna, Austria) with the packages dpIR, nparcomp, and nlme.

\section{Results}

\section{BEECH STEM INCREMENT AND CANOPY STRUCTURE AS INFLUENCED BY CLAY CONTENT}

Before analyzing a possible neighbourhood effect on beech stem growth, the influence of edaphic heterogeneity (clay content) on stem increment was quantified which interfered with the former. Comparing the 77 and 72 tree groups with a Fagus target tree that grew either on soils with a lower clay content $(\leq 22 \%)$ or a higher clay content $(>22 \%)$ revealed significant differences with respect to various canopy structural properties and growth parameters of Fagus (Table 1). Tree groups on clayricher soil (mean clay content 29.3\%) were significantly more diverse in terms of tree species (Shannon index $\mathrm{H}^{\prime}$ ), had a higher mean annual increment of the target Fagus stems and shared a greater sensitivity to environmental variation of annual ring width (observation interval: full length of the ring series) than tree groups on soils with lower clay content (mean clay content 16.6\%). In contrast, clay content had no influence on several other structural attributes of the canopy (crown area of the target tree, number of stems per cluster, gap fraction, competition index). Moreover, tree groups on clay-richer and clay-poorer soil did not differ significantly with respect to the abundance of other beech 
stems in the neighbourhood of the target tree, i.e. the relative contribution of Fagus to the competition index, which characterizes the density and size of the competitors.

Table 1. Variables characterizing stand structure and soil, the stem neighbourhood and ring series characteristics of target Fagus trees on soils with a lower $(\leq 22 \%)$ or higher $(>22 \%)$ clay content.

\begin{tabular}{|c|c|c|c|c|c|c|c|}
\hline \multirow[b]{2}{*}{ Number of tree clusters } & \multicolumn{3}{|c|}{ Lower clay } & \multicolumn{3}{|c|}{ Higher clay content* } & \multirow{2}{*}{$p^{*}$} \\
\hline & & 77 & & & 72 & & \\
\hline Number of stems per cluster & 5 & \pm & 1.6 & 4.9 & \pm & 1.6 & 0.79 \\
\hline Relative contribution of Fagus to the competition index $\mathrm{Cl}_{\text {rel }}[\%]$ & 0.78 & \pm & 0.29 & 0.74 & \pm & 0.26 & 0.09 \\
\hline Clay content [\%] & 16.6 & \pm & 2.9 & 29.3 & \pm & 4.5 & $<0.001$ \\
\hline Tree age $[y r]$ & 119.1 & \pm & 35.7 & 112.1 & \pm & 23.4 & 0.41 \\
\hline Gap fraction [\%] & 18.9 & \pm & 3.3 & 19.2 & \pm & 3.7 & 0.53 \\
\hline Variability of tree height [CV in \%] & 18.3 & \pm & 8.1 & 17.2 & \pm & 7.8 & 0.24 \\
\hline Crown area of the target tree $\left[\mathrm{m}^{2}\right]$ & 51.7 & \pm & 24.4 & 50.35 & \pm & 19.7 & 0.85 \\
\hline Competition index after Hegyi $(\mathrm{Cl})$ & 1.01 & \pm & 0.48 & 0.9 & \pm & 0.33 & 0.24 \\
\hline Shannon index $\left(\mathrm{H}^{\prime}\right)$ & 0.35 & \pm & 0.37 & 0.47 & \pm & 0.35 & 0.04 \\
\hline Mean annual increment 1986-2005 [1/100 mm] & 195.6 & \pm & 91.9 & 229.5 & \pm & 83.4 & 0.02 \\
\hline Ring series sensitivity $1986-2005$ & 0.34 & \pm & 0.15 & 0.35 & \pm & 0.11 & 0.31 \\
\hline Ring series sensitivity of the entire series & 0.26 & \pm & 0.05 & 0.32 & \pm & 0.06 & $<0.001$ \\
\hline
\end{tabular}

*Given are means \pm standard deviation and the $p$-value (two-sided, permuted, non-parametric t-test after Hothorn et al. 2008).

A more detailed analysis of Fagus stem increment in clusters either on clay-poorer or clay-richer soil revealed a different behaviour of the two groups which demanded for a separate analysis. Figure 1 shows that beeches on soils with lower or higher clay content do not differ with regard to mean radial increment in the period 1986-2005 in the majority of neighbourhood constellations. However, Fagus trees which are surrounded by many allospecific stems (Fagus $<70$, i.e. Fagus neighbours contribute by less than $70 \%$ to the competition index $\mathrm{Cl}$ of the tree cluster) grew significantly better in the last 20 years than beech trees with $100 \%$ contribution of conspecific trees to $\mathrm{Cl}$ (Fig. 1: left panel). This neighbourhood effect was only visible in the group on soils with lower clay content, but was absent on clay-richer soils.

Fig. 1. Mean annual increment of Fagus trees in the period 1986-2005 in three different neighbourhood categories (only conspecific neighbours: Fagus100, few allospecific neighbours, many Fagus neighbours: Fagus7099, many allospecific and also Fagus neighbours: Fagus $<70$ ). Sites with lower $(\leq 22 \%)$ and higher clay content $(>22 \%)$ of the soil are distinguished. Different letters indicate significant differences $(p<0.05)$ within the group of clay-poorer sites (lower case), clayricher sites (upper case) and among all 6 groups of neighbourhoods on clay-poorer and clay-richer soils (greek letters). Boxes indicate the $25 \%$ and $75 \%$ quartiles, the bold line shows the median, whiskers stand for the data range.



Higher clay content

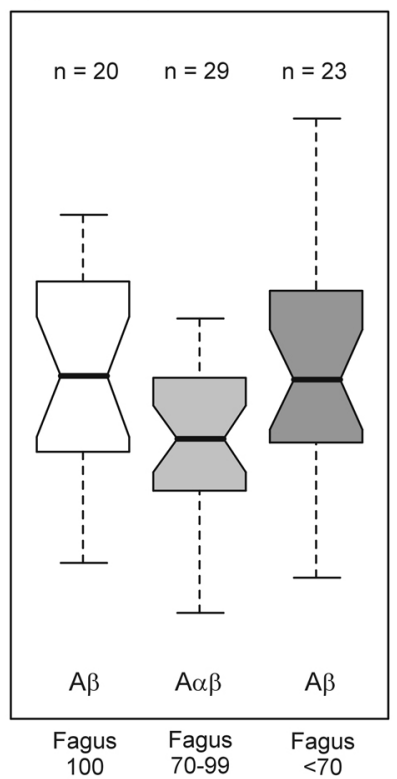


A cluster analysis, which grouped the ring series of the target Fagus trees according to similarity of growth trends and interannual increment variability in the years 1981-2005, yielded 6 identifiable response types (Fig. 2), which were partly defined by the clay content of the soils the tree clusters were growing on. Fagus trees grouped to the response clusters \#1, 2 or 4 grew mostly on clay-poorer soils than trees grouped to the clusters \#3, 5 or 6 (Table 2).

The ring chronologies of the trees in clusters \#1, 2 and 4 had in common that Fagus increment was lower than average not only in the period 2000-2005, but also in the middle (and partly the end) of the 1990s (Fig. 2). Trees grouped in the clusters \#5 and 6, which were related to clay-richer soils, showed less distinct growth depressions from 2000-2005 but were characterized by a low increment in the interval 19881993; cluster \#3 was somewhat intermediate between the clusters \#1, $2 \& 4$, and $5 \& 6$ with respect to its growth response.

Fig. 2. Six types of tree ring chronologies (period 1981-2005, averages) obtained by a cluster analysis. Each cluster contains at least 7 trees (clusters with a smaller number of trees are not presented). In total, 152 trees were considered for the clustering. Increment below the 26-yr average is indicated by black areas, increment above the average by grey areas.

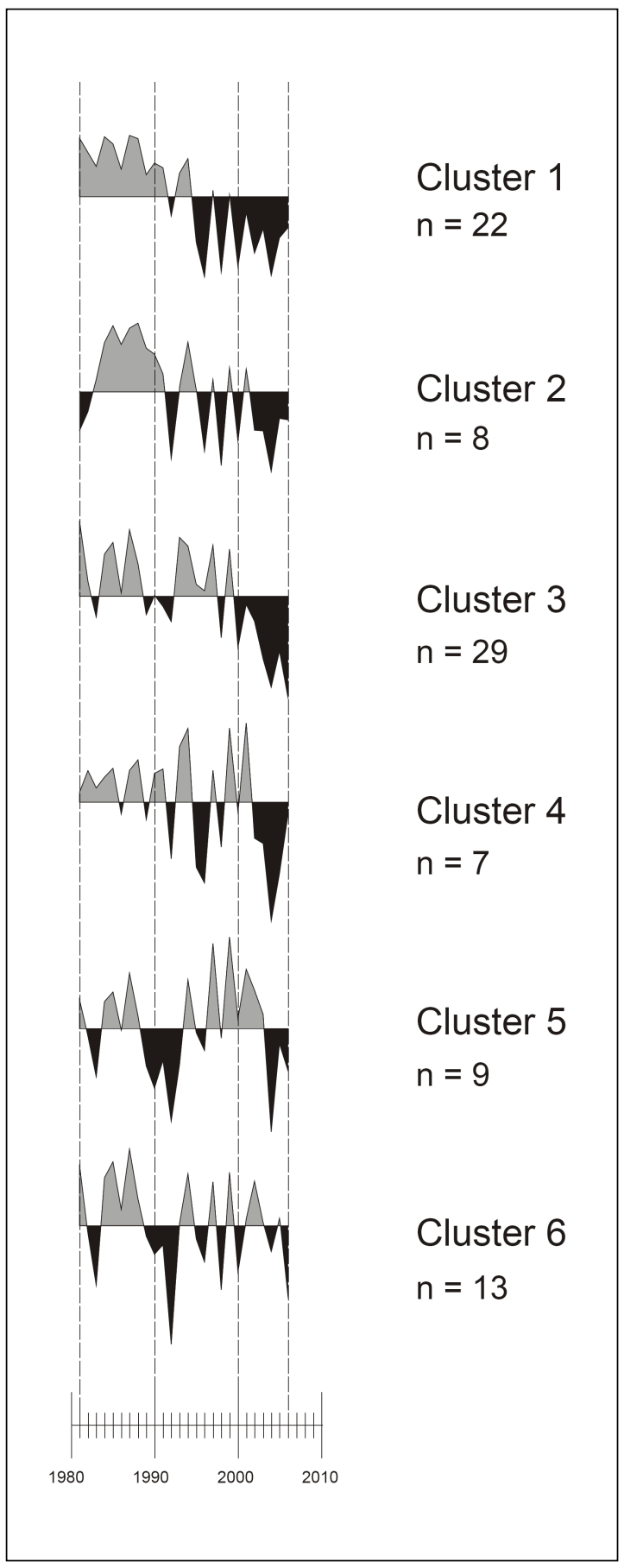

Table 2. Squared residuals from contingency tables (deviation between observed and expected abundance) of site categories with regard to clay content in the six types of Fagus ring chronologies (period 1981-2006) detected by cluster analysis (see Fig. 2).

${ }^{*} \mathrm{~A}(+)$ sign behind the residual indicates greater abundance of the given neighbourhood category in the ring chronology type than expected, a (-) sign stands for underrepresentation.

N Lower clay Higher clay content $^{*}$ content*

\begin{tabular}{lrll}
\hline Cluster1 & 22 & $3.49(+)$ & $2.21(-)$ \\
Cluster2 & 8 & $3.96(+)$ & $2.52(-)$ \\
Cluster3 & 29 & $1.61(-)$ & $1.02(+)$ \\
Cluster4 & 7 & $1.92(+)$ & $1.22(-)$ \\
Cluster5 & 9 & $1.78(-)$ & $1.13(+)$ \\
Cluster6 & 13 & $4.27(-)$ & $2.71(+)$
\end{tabular}




\section{BEECH STEM INCREMENT IN THE NEIGHBOURHOOD OF CONSPECIFIC OR ALLOSPECIFIC TREES}

Because increment differences between contrasting neighbourhood constellations were found to be significant only in the Fagus group on soils with lower clay content (Fig. 1), we restricted the subsequent analyses mostly to this sub-sample of 77 tree clusters. The clay-rich sub-sample was only included in the analysis of possible species effects in the neighbourhood on growth responses of Fagus. As stated earlier, Fagus target trees, which were surrounded by a greater number of allospecific stems, had a significantly higher stem increment in the last 20 years as compared to beeches in pure stands where all neighbours were conspecific. The positive effect of allospecific neighbours was restricted to tree clusters in which Fagus contributes by less than $70 \%$ to the competition index of the neighbour group (Fagus $<70$ ), while the effect was not significant in the Fagus70-99 group which is more similar to the entirely conspecific Fagus 100 group (Table 3). A second result of the analysis is that target trees exposed to the most diverse Fagus $<70$ neighbourhood were less sensitive to environmental fluctuation in 1986-2005 than were Fagus trees growing in conspecific neighbourhood (Fagus100, Table 3). This finding is supported by the results of generalized linear models revealing a positive effect of Shannon diversity on growth in the negative pointer year 2004. In combination with $\mathrm{Cl}(\mathrm{p}=0.065$, effect negative), Shannon diversity had a negative effect on mean sensitivity in the period 1986-2005 ( $p=0.007$, data log-transformed). However, the allospecific Fagus $<70$ neighbourhood had no significant influence on ring series sensitivity when a longer time span (entire series: > 80 years) was considered. Similarly, target trees in the Fagus $<70$ neighbour-hood did not grow better in the positive pointer year 1999 than did beeches in Fagus 100 clusters.

Table 3. Comparison of the effect of neighbourhoods with a relatively small (Fagus $<70$ ) or high (Fagus70-99) proportion of Fagus trees with the effect of entirely conspecific neighbourhoods (only Fagus trees; Fagus100) as explaining variables on various stem increment parameters for Fagus trees on soils with lower clay content (dependent variables).

\begin{tabular}{|c|c|c|}
\hline \multirow[t]{2}{*}{ Dependent variable } & \multicolumn{2}{|c|}{ Explaining variable* } \\
\hline & Fagus $70-99$ & Fagus $<70$ \\
\hline \multicolumn{3}{|l|}{ Ring series characteristics } \\
\hline \multicolumn{3}{|l|}{ Positive pointer year 1999 [\% dev.[ } \\
\hline Recent ring series sensitivity $1986-2005$ & $0.064(-)$ & $0.002(-)$ \\
\hline \multicolumn{3}{|c|}{ General ring series sensitivity of the entire series } \\
\hline Mean annual increment $[1 / 100 \mathrm{~mm}]$ & & $0.004(+)$ \\
\hline \multicolumn{3}{|l|}{ Increment in negative pointer years } \\
\hline 2004 vs. 2003 & & $0.024(+)$ \\
\hline \multicolumn{3}{|l|}{1992 vs. 1991} \\
\hline 1976 vs. 1975 & $0.010(+)$ & \\
\hline \\
\hline & \multicolumn{2}{|c|}{ Increment $1992-2005$ relative to } \\
\hline \multirow{2}{*}{\multicolumn{3}{|c|}{$\begin{array}{l}\text { increment } 1991 \\
\text { increment 1987-91 }\end{array}$}} \\
\hline & & \\
\hline \multicolumn{3}{|l|}{ Increment $1976-2005$ relative to } \\
\hline increment 1975 & $0.029(-)$ & \\
\hline increment 1971-1975 & $0.058(-)$ & \\
\hline
\end{tabular}

*Given are permuted two-sided p-values for the non-parametric t-test after Hothorn et al. (2008) for the Behrens-Fisher problem (hypothesis $H_{0}: p=1 / 2$, with $p$ denoting the relative effect of 2 independent samples). Differences with $p<0.05$ are printed in bold, those with $0.05<p<0.1$ in normal fonts; no $p$-values stand for $p>0.1$. A ( - ) sign stands for a lowered sensitivity, a lower mean increment or a reduced number of years to recover from drought (more rapid recovery). A $(+)$ sign indicates a higher sensitivity, a higher mean annual increment, a higher increment in a negative pointer year (smaller growth reduction), or a longer period needed for recovery. 1976, 1992 and 2004 were negative pointer years, the preceding years $(1975,1991,2003)$ were used to compare increment with a normal year. The drought in 2003 occurred late in summer with the consequence that most trees showed the growth reduction in 2004 while 2003 shared average growth. 
Neighbourhood effects were also found to manifest in the increment response to a drought event which often results in a negative pointer year in the actual or the subsequent annual ring. The severe drought of 2003 resulted in a significantly smaller growth reduction in those Fagus trees that grew in the more allospecific Fagus $<70$ neighbourhoods than the target trees in completely conspecific (Fagus100) tree clusters (Table 3). Again, the less diverse Fagus70-99 group did not differ significantly from the Fagus 100 group in the extent of growth reduction to the 2003 drought. A reduced sensitivity of the Fagus $<70$ trees was not observed as a response to 1976 or 1992 , two other negative pointer years investigated. However, the Fagus70-99 group with only a few allospecific, but many conspecific, neighbours responded less sensitively to the 1976 drought (smaller increment reduction) than the conspecific Fagus100 group and recovered within one year (median) from this stress event, while the beeches in the Fagus100 group required on average three years (median) for increment recovery.

Similar to the two clay content classes, which were associated with certain types of beech ring chronologies (see Fig. 2), we found relationships between the Fagus abundance in the neighbourhood and several ring chronology clusters. For example, beech trees in the group Fagus $<70$ were overrepresented in the cluster \#3 of Fig. 2 and Table 4 (all 152 trees considered), while trees with conspecific neighbourhood (Fagus100) were concentrated in cluster \#4, two growth response types which differed most with respect to a marked increment depression in the years 1994/1995 and 2000 . If only Fagus trees on soils with a lower clay content are considered (Fig. 3, Table 5), the most striking association between neighbourhood category and ring chronology type was the overrepresentation of the conspecific Fagus100 group in cluster \#4 which was characterized by three main growth depressions in 1992, 1994/1995 and 2003/2004. However, the association between neighbourhood category with variable degrees of Fagus contribution (Fagus $<70$ to Fagus 100 ) and the 6 or 4 ring chronology types identified by the cluster analysis was generally small, as is visible from the contrasting response types in clusters \#1, 2 and 3 , which showed no significant difference in the neighbourhood categories being present in these clusters.

Table 4. Squared residuals from contingency tables (deviation between observed and expected abundance) of neighbourhood categories (abundant species in allospecific neighbourhood, Fagus100, Fagus70-99 or Fagus $<70$ ) in the six types of Fagus ring chronologies (interval 1981 and 2006) detected by cluster analysis of tree-ring series from sites with clay-poorer and clay-richer soils (see Fig. 2).

\begin{tabular}{lrlllllll}
\hline & N & \multicolumn{3}{c}{$\begin{array}{c}\text { Abundant species in the neighbourhood* } \\
\text { Tilia }\end{array}$} & Fraxinus & Quercus & Acer & \multicolumn{2}{c}{ Fagus abundance in the neighbourhood* } \\
& & Fagus100 & Fagus70-99 & Fagus $<70$ \\
\hline Cluster1 & 22 & 0.01 & 0.1 & $1.39(+)$ & 0.59 & 0.2 & 0.03 & 0.08 \\
Cluster2 & 8 & 0.02 & 0 & 0.42 & 0.91 & 0.24 & 0.03 & 0.12 \\
Cluster3 & 29 & 0.07 & 0.12 & $1.88(-)$ & 0.51 & 0 & 0.84 & $1.08(+)$ \\
Cluster4 & 7 & 0.61 & 0.67 & 0.78 & $1.60(+)$ & $2.60(+)$ & 0.06 & $2.15(-)$ \\
Cluster5 & 9 & 0.36 & 0.05 & 0.16 & 0 & 0.22 & 0 & 0.21 \\
Cluster6 & 13 & 0.22 & 0.1 & 0.02 & 0 & $2.80(-)$ & $2.87(+)$ & 0 \\
\hline
\end{tabular}


Table 5. Squared residuals from contingency tables (deviation between observed and expected abundance) of neighbourhood categories (abundant species in allospecific neighbourhood, Fagus100, Fagus70-99 or Fagus $<70$ ) in the four types of Fagus ring chronologies (interval 1981 and 2006) detected by cluster analysis of tree-ring series from sites with clay-poorer soils (see Fig. 3).

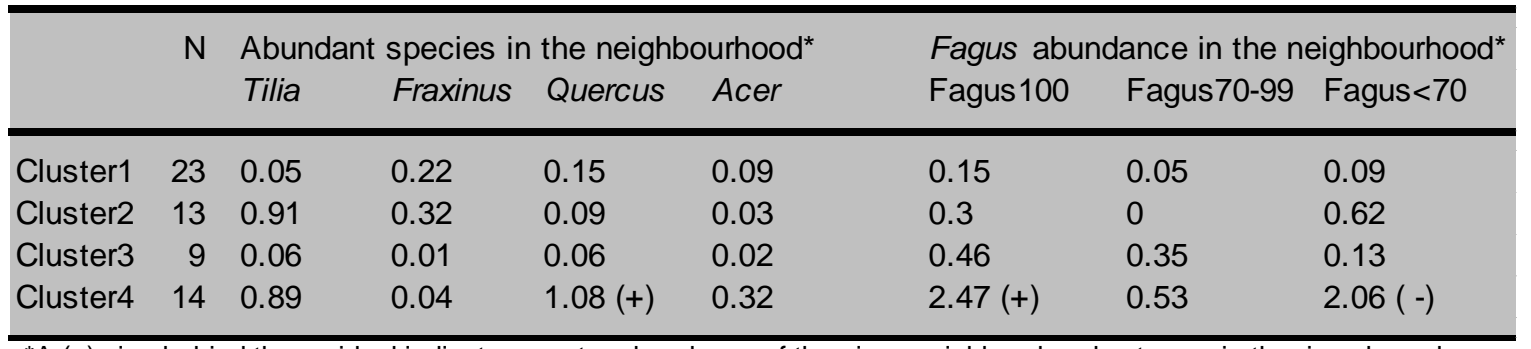

${ }^{*} \mathrm{~A}(+)$ sign behind the residual indicates greater abundance of the given neighbourhood category in the ring chronology type than expected, a (-) sign stands for underrepresentation.

We expressed the variable presence of Fagus trees in the neighbourhood of the beech target trees by the Fagus contribution to the competition index $\mathrm{Cl}$, which is a measure of stem density and tree size of the competitors in the neighbourhood. Generalized linear models revealed a positive effect of an increasing proportion of Fagus in $\mathrm{Cl}$ on ring series sensitivity in the period 1986-2005 and over the full length of the ring series (> 80 years). Thus, a higher environmental sensitivity of stem increment of beech was associated with a higher relative importance of intraspecific competition $(p<0.001$, the variables "proportion of Fagus in Cl" and the size of $\mathrm{Cl}$ itself interacted and had a significant negative influence on increment). In contrast, we detected no significant effect of the relative importance of Fagus in $\mathrm{Cl}$ on mean annual increment or the response to negative or positive pointer years of the beech target trees (Table 4). Crowding in the neighbourhood as expressed by the size of $\mathrm{Cl}$ did not reduce mean stem increment of Fagus in our data set (results not shown).

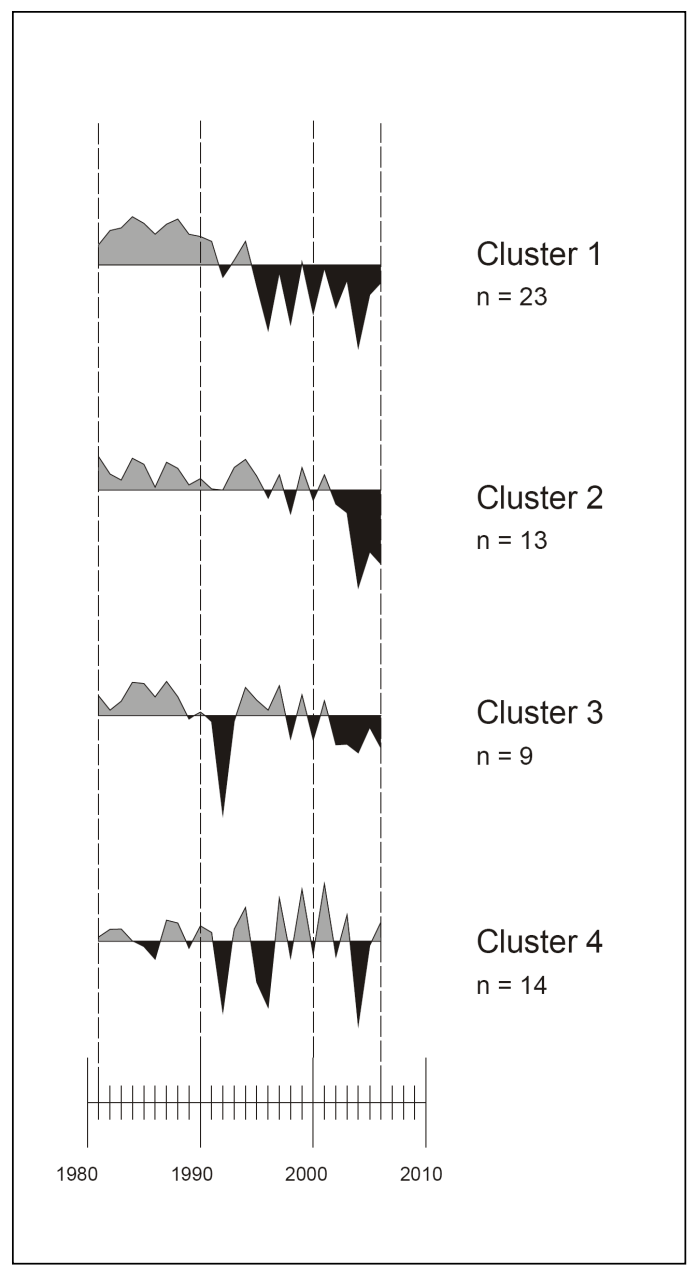

Fig 3. Four types of tree ring chronologies (period 1981-2005, averages) obtained by a cluster analysis of Fagus trees from sites with a lower soil clay content. Each cluster contains at least 9 trees (clusters with a smaller number of trees are not presented). In total, 77 trees were considered for the clustering. Increment below the 26 -yr average is indicated by black areas, increment above the average by grey areas.

\section{BEECH STEM INCREMENT IN THE NEIGHBOURHOOD OF DIFFERENT SPECIES}

In the search for possible species effects of the neighbours on Fagus stem increment, we separately analyzed allospecific tree clusters (Fagus70-99 and Fagus $<70$ groups) with presence of either Tilia, Fraxinus, Quercus or Acer stems and tested for significant differences in various growth parameters 
between these four species-related sub-samples and the growth in conspecific neighbourhood (Fagus100 group). If only the tree clusters on soils with lower clay content were taken into account, we found a significantly smaller ring series sensitivity (1986-2005 series) to environmental variation when Tilia grew in the direct neighbourhood of a Fagus target tree than when exposed to intraspecific (Fagus100) neighbourhoods (Table 6). Moreover, Fagus in neighbourhood to Tilia reached a higher mean annual increment and suffered less from the 2003 drought than in the conspecific Fagus 100 group. In addition, Fagus recovered faster from the 1976 drought when associated with Tilia. Target trees growing in the proximity of Tilia also had larger crowns as compared to beeches with conspecific neighbourhood (Table 7).

Table 6. Comparison of the effect of defined partly allospecific neighbourhood constellations with Tilia, Fraxinus, Quercus or Acer (species composition as explaining variable; trees from the categories Fagus70-99 and Fagus $<70$ ) with the effect of conspecific neighbourhood (only Fagus trees; Fagus100) on various stem increment parameters of Fagus trees on soils with lower clay content (dependent variables).

\begin{tabular}{|c|c|c|c|c|}
\hline \multirow[t]{2}{*}{ Dependent variable } & \multicolumn{4}{|c|}{ Explaining variable* } \\
\hline & Tilia & Fraxinus & Quercus & Acer \\
\hline \multicolumn{5}{|l|}{ Ring series characteristics } \\
\hline Ring series sensitivity 1986-2005 & $0.001(-)$ & $0.025(-)$ & $0.052(-)$ & $0.001(-)$ \\
\hline Ring series sensitivity of entire series & & & & $0.001(-)$ \\
\hline Mean annual increment & $0.040(+)$ & $0.020(+)$ & & $0.001(+)$ \\
\hline \multicolumn{5}{|c|}{ Increment in negative pointer years } \\
\hline \multicolumn{4}{|l|}{1992 vs. 1991} & $0.031(+)$ \\
\hline 1976 vs. 1975 & & & & $0.075(+)$ \\
\hline \multicolumn{5}{|c|}{$\begin{array}{l}\text { Increment recovery from negative pointer years } \\
\text { Increment } 1992-2005 \text { relative to }\end{array}$} \\
\hline $\begin{array}{l}\text { increment } 1991 \\
\text { increment 1987-91 }\end{array}$ & & & $0.007(-)$ & \\
\hline $\begin{array}{l}\text { Increment 1976-2005 relative to } \\
\text { increment } 1975\end{array}$ & & & & \\
\hline increment 1971-1975 & $0.070(-)$ & & & \\
\hline
\end{tabular}

*Given are p-values and the direction of the relationship. A (-) sign stands for a lowered sensitivity and reduced number of years to recover from 1992 or 1976. A (+) sign indicates higher mean annual increment and smaller increment reduction in the negative pointer years $(2004,1976)$. For further explanations see Table 3.

Table 7. Comparison of the effect of defined partly allospecific neighbourhood constellations with Tilia, Fraxinus, Quercus and Acer (species composition as explaining variable; trees from the groups Fagus70-99 and Fagus $<70$ ) with the effect of conspecific neighbourhood (only Fagus trees; Fagus100) on variables characterizing the canopy structure and competition intensity (dependent variables) in the neighbourhood of the Fagus target trees on soils with lower clay content

\begin{tabular}{|c|c|c|c|c|}
\hline \multirow[t]{2}{*}{ Dependent variable } & \multicolumn{2}{|c|}{ Explaining variable* } & \multirow[b]{2}{*}{ Quercus } & \multirow[b]{2}{*}{ Acer } \\
\hline & Tilia & Fraxinus & & \\
\hline Gap fraction [\%] & & $0.092(+)$ & & $0.002(+)$ \\
\hline Crown area of the target tree $\left[\mathrm{m}^{2}\right]$ & $0.015(+)$ & & & \\
\hline Variability of tree height (CV in \%) & & & & \\
\hline Competition index $\mathrm{Cl}$ & & $0.044(+)$ & & \\
\hline
\end{tabular}

*Given are permuted two-sided p-values for the non-parametric t-test after Hothorn et al (2008) for the Behrens-Fisher problem (hypothesis $H_{0}: p=1 / 2$, with $p$ denoting the relative effect of 2 independent samples). Four different neighbourhood classes are distinguished (Tilia, Fraxinus, Quercus or Acer). Differences with $\mathrm{p}<0.05$ are printed in bold, those with $0.05<\mathrm{p}<0.1$ in normal fonts; no $p$-values stand for $p>0.1$. A ( -)-sign or a (+)-sign indicate the direction of the relationship. 
A neighbourhood to Fraxinus was characterized by a higher gap fraction of the canopy in the tree group but also a higher competition index (Table 7) as compared to Fagus 100 clusters. The constellation with Fraxinus was associated with a reduced ring series sensitivity (period 1986-2005) and higher mean annual increment of Fagus (Table 6). For the neighbourhood to Quercus, we detected a significantly shorter increment recovery period after the negative pointer year 1992, and a smaller ring series sensitivity in Fagus $(p=0.052)$ as compared to conspecific neighbourhood. Proximity to Acer trees increased the mean increment of beech, decreased the ring series sensitivity and the growth reduction due to the 1976 and 2003 droughts; in addition, beeches growing in neighbourhood of Acer trees may have profited from a larger gap fraction (Table 7). The tree-species diversity in the neighbourhood of a beech target tree (expressed by Shannon's H') had no significant effect on mean increment but was negatively associated with increment sensitivity, i.e. more diverse neighbourhoods seem to result in higher resistance of Fagus to climatic stress.

While we found evidence of a significant effect of Tilia, Fraxinus, Quercus and Acer on mean increment and increment sensitivity of Fagus, when growing in proximity, the species identity was, in most cases, not significantly associated with the six (or four) types of ring chronologies that we identified for the 1981-2003 period (Tables 4 and 5). Apparent exceptions were Quercus (cluster \#1 in Fig. 2; cluster \#4 in Fig. 3) and Acer (cluster \#4 in Fig. 2) with an overrepresentation in these growth response types.

\section{Discussion}

\section{TREE-SPECIES DIVERSITY AND FOREST PRODUCTIVITY}

Our study provided dendrochronological evidence that Fagus sylvatica trees show higher mean radial stem growth rates when they are surrounded by a number of other tree species as compared to an entirely conspecific neighbourhood. Thus, tree-species diversity or tree identity in the neighbourhood, or both, matter for the stem growth of beech, at least on sites in the Hainich forest with soil clay contents $\leq 22 \%$. In the following, we will discuss this finding in the context of the diversity-ecosystem function debate and attempt to identify possible underlying mechanisms of the apparent neighbourhood dependency of beech growth.

It is important to distinguish between productivity data relating to the stand and those relating to the tree individual. Our results for the 77 beech trees on soil with lower clay content proof a better radial increment of the Fagus $<70$ neighbourhood category at the stem level, but not on the stand or tree cluster (neighbourhood group) level. In fact, investigations on stem wood production on the stand level in our study plots showed that diverse beech-linden-ash-hornbeam-lime stands were not more productive than monospecific beech stands on similar soil (Jacob et al. 2010). The positive effect of a predominantly allospecific neighbourhood on beech stem growth existed, even though a diversity or tree identity effect on stand productivity was not significant. Thus, it is important to distinguish between different spatial scales in the debate on possible effects of tree-species diversity or functional diversity on tree and forest productivity. Positive (or negative) effects of a more diverse neighbourhood on the 
growth of a single tree species may be insignificant at the stand level where the productivity of all species counts and a multitude of interactions between individuals of different species is involved.

The significance of neighbourhood effects may depend on the environment: Pretzsch \& Schütze (2009) found that competitively superior tree species in mixed stands profited most from the presence of allospecific neighbours when soil fertility was high. In the Hainich forest, neighbourhood effects appeared only when soil clay content was $\leq 22 \%$ which may represent more favourable growth conditions in terms of soil aeration, but not with respect to nutrient supply.

\section{THE ROLE OF COMPETITION IN TREE NEIGHBOURHOOD EFFECTS ON GROWTH}

In theory, a better growth of beech in species-rich stands with lime, ash, maple or other species as compared to growth in monospecific beech stands may have different causes. Competition between beech and its allospecific neighbours could be asymmetric in favour of Fagus, or, in other words, intraspecific competition could be more harmful for beech growth than interspecific competition. Different competitive interactions could play a role, among them competition for light (Nakashizuka et al. 2002), for water and nutrients, and direct mechanical interactions between the branches of neighbouring trees. Fagus sylvatica is known to be a superior competitor for light that reduces belowcanopy photon flux density typically to $1-3 \%$ of incident radiation in closed forests (Ellenberg \& Leuschner, in press) and thus outcompetes species such as Fraxinus excelsior and Quercus robur and petraea which produce lower shade levels. The Tilia and Acer species and also Carpinus betulus, on the other hand, are casting deeper shade and light competition with Fagus may be not as asymmetric as in the case of Fraxinus or Quercus. Inherently different height growth patterns of species may also play a decisive role for the outcome of interspecific competition in mixed forests (Oliver \& Larson 1990; Bauhus et al. 2004; Amoroso \& Turnblom 2006). Interestingly, by measuring annual growth of lateral twigs in the sun canopy of the Hainich mixed forest, Frech (2006) could show that mechanical interactions between neighbouring trees of different species are asymmetric and may lead to the canopy expansion of a mechanically more robust species on the expense of an inferior competitor which is damaged by the moving twigs of its neighbour. F. excelsior was found to be particularly sensitive to mechanical damage by interspecific and, in particular, intraspecific neighbours with the result that ash crowns have a relatively small horizontal extension in the Hainich mixed stands while height growth is not restricted by the presence of neighbours (Frech 2006). Thus, these results indicate that mechanical interactions in the competition for canopy space may in certain cases be as important as is competition for light in mixed broad-leaved forests. This phenomenon deserves more attention in forest dynamics research.

Belowground competition between the root systems of different tree individuals of tree species in mixed forests has only recently been studied in more detail. It has been argued that root competition should be more symmetric than above-ground competition (e.g., Schwinning \& Weiner 1998; Cahill \& Casper 2000; Wettberg \& Weiner 2003), but theoretical considerations (Schwinning 1996) and evidence from experimental studies on root competition in forests (Hertel \& Leuschner 2006; Rewald 2008) suggest that root competition between mature trees can be as asymmetric as aboveground competition. Root chamber experiments with fine roots of two adult trees conducted in situ in the forest 
floor provided evidence for superior and inferior competitors in the rooting space of mixed forests, providing a possible explanation for the better growth of beech trees in neighbourhood of allospecific trees. For example, beech fine roots grew better in the neighbourhood of oak (Quercus petraea) roots than when exposed to conspecific roots in an experiment in moist sandy soil (Hertel \& Leuschner 2006). However, opposite growth responses were obtained in a second experiment with root growth chambers in temporarily dry soil rich in silt (Rewald 2008). Thus, it appears that the outcome of competitive interactions among tree roots does not only depend on the species but also on edaphic properties and soil moisture availability. Fine root inventories in the Hainich forest revealed a complete overlap of the root systems of different trees and tree species which indicated that root competition most likely was a relevant factor (Canham et al. 2004; Meinen 2008). However, in the absence of root competition experiments it must remain open whether asymmetric root competition is a factor contributing to the better growth of Fagus in allospecific neighbourhoods.

\section{FACILITATION AND OTHER POSSIBLE MECHANISMS OF INTERACTION}

Positive interactions among neighbouring trees could also lead to a better growth in mixed stands if they are more pronounced in interspecific than in intraspecific interactions (Brooker et al. 2008). Possible mechanisms are nutrient (in particular Calcium) pumping by deeper-rooted species, or the production of nutrient-rich, rapidly decomposing litter which could stimulate growth through a better nutrient supply (Rothe \& Binkley 2001). In fact, we found a more rapid decomposition and faster $\mathrm{N}$ release from leaf litter in mixed stands of the Hainich than in monospecific beech stands (Jacob et al. 2009). Beech as a species with a rather high water consumption could also profit from allospecific neighbours which use water more conservatively than does F. sylvatica (Köcher et al. 2009). Thus, allospecific neighbours might facilitate better growth of beech directly by supplying more resources (as may be assumed in the case of nutrients) or indirectly through reduced resource consumption (as for water).

In addition, indirect interactions through third-party effects might be responsible for a better beech growth in mixed stands. Analyses of the invertebrate fauna in the Hainich forest make it likely that species-rich stands may benefit from a lower leaf herbivory rate than monospecific beech stands (Sobek 2008). This would be in line with results of a meta-analysis on tree diversity effects on leaf herbivory in forests showing a significant reduction in foliage loss due to consumption with increasing tree-species richness (Jactel et al. 2005). The fact that the Hainich mixed forests harbored a more species-rich ectomycorrhiza-forming fungal community than the pure beech stands (Lang 2008) could indicate that the mycorrhizal network is functionally more diverse and, perhaps, more efficient in nitrogen and phosphorus acquisition when beech is growing in species-rich stands (Callaway 1995). Other third-party effects (e.g., via the rhizofauna or pathogens) in species-rich stands are also possible. 


\section{NEIGHBOURHOOD EFFECTS ON STRESS SENSITIVITY AND RESILIENCE OF GROWTH}

Fagus trees with a predominantly allospecific neighbourhood (Fagus $<70$ category) did not only reach a higher mean annual increment but were also less sensitive in growth to environmental fluctuation, in particular to the severe drought in 2003, as compared to beech trees in pure beech neighbourhood. Beeches with a few allospecific neighbours (Fagus70-99 category) reduced growth to a smaller extent in the negative pointer year 1976 than beeches in pure stands and they also recovered more rapidly in terms of stem increment after the 1976 drought. Thus, the presence of allospecific neighbours seems to buffer Fagus trees from environmental hazards which result in growth reductions. Earlier dendrochronological analyses showed that in the rather clay-rich soils of the Hainich forest with high bulk density the largest effect on interannual stem growth variability is exerted by soil moisture availability in summer (Frech 2006). We explain the fact that neighbour effects occurred primarily in tree groups on soils with lower clay content by the generally higher drought exposure of the stands on clay-richer soils which seems to affect all trees and is likely to mask any neighbourhood effect on water status and growth.

One possible mechanism by which allospecific neighbours may reduce the drought stress sensitivity of a target tree could be a relatively low water consumption of the neighbouring trees, as it is the case in F. excelsior (Köcher et al. 2009, Gebauer et al. 2008). A second explanation may be provided by root space partitioning between different individuals or species which would reduce competition for water by exploring additional water reserves in deeper soil layers. Alternatively, differences in the phenological development of leaf area among the coexisting species could also result in a temporal reduction of competition intensity for water. Whatsoever the reason of the observed reduced environmental sensitivity of Fagus stem growth is, it is likely that besides drought stress other factors are also influential. Target trees with a higher mean increment as observed in the Fagus $<70$ group are likely to possess an enhanced ability to cope with stressful periods and to recover more rapidly after a stress event (Bonn 1998, Pedersen 1998). Thus, a more open canopy or a better nutrient supply in allospecific neighbourhoods are additional putative causes of the lower growth sensitivity in this neighbourhood category.

While the character of the beech neighbourhood seems to influence the Fagus growth response to certain stress events (e.g. the drought summers 1976 and 2003), it had no significant effect on others (e.g. the negative pointer year 1992). Moreover the neighbourhood seems to have only a weak or negligible effect on the 26-yr ring chronologies, i.e. the long-term response types identified by cluster analyses (see Fig. 2 and 3). We assume that the neighbourhood represents an environmental factor which is only secondary to climate variability, soil conditions and light availability as a factor controlling annual ring width. Thus, the neighbourhood may influence the growth response under certain conditions, but this factor is too weak to determine principal types in the growth-environment relationship of Fagus. The relatively large edaphic influence on the growth response types is demonstrated by the deviating results of cluster analyses conducted with Fagus trees on clay-poorer soils (Fig. 3) or on all soils (Fig. 2). 


\section{STAND DENSITY AND FOREST MANAGEMENT EFFECTS ON GROWTH}

Stem density and neighbour crowding are the best studied stand structural factors influencing the radial increment of trees (e.g., Hegyi 1974; Tome \& Burkhart 1989; Vacek \& Lepš 1996; Weber et al. 2008). The negative neighbour crowding effect on stem growth of a target tree is most often explained by competition for light (Oliver \& Larson 1990; Canham et al. 2004), less frequently by competition for water or nutrients. Foresters reduce competition intensity by regular thinning which increases the radial growth of the remaining trees (Badeau et al. 1995). We used Hegyi's competition index Cl, which measures the presence of neighbours in the "influence sphere" of a target tree, as a more precise measure than stem density, to express the degree of neighbour crowding in a given tree cluster. In contrast to our expectation, we did not find a significant decrease in mean annual increment of Fagus with an increase in $\mathrm{Cl}$, i.e. neighbour crowding, neither on soils with lower nor with higher clay content. This observation contrasts with the results of other studies in forest stands with variable stem densities, e.g. in Picea mariana (Mill.) BSP stands (Mailly et al. 2003). In fact, tree-species identity and the importance of different species in the competition index of a Fagus neighbourhood were more important in the Hainich forest than the magnitude of $\mathrm{Cl}$ itself.

Changes in forest management may have influenced the Fagus growth trends in the past 10 to 15 years. While the Hainich forest was subject to extensive forest management with a selective cutting regime and the extraction of single stems in the 1960s to 1990s, the area became a national park with termination of all forest management activities in 1998. Thus, decreasing annual growth rates as observed in many beech trees during the past 8 to 15 years may partly be a consequence of increasing canopy closure which may have increased competition for light in the stands.

\section{THE ROLE OF THE NEIGHBOUR'S SPECIES IDENTITY}

From forest dynamics studies, it is well known that many pairwise interactions between two tree species are asymmetric, resulting in the suppression and eventual loss of populations of inferior species in the stand (Oliver \& Larson 1990; Canham et al. 2006). Other species clearly benefit from interspecific competition (Canham et al. 2004; Amoroso \& Turnblom 2006) if the interaction in mixture is less intense than intraspecific competition in monoculture. The magnitude of a species' effect on the productivity of a competitor will depend on the growth characteristics, the minimum resource demand and the capability for resource depletion of this species (Tilman 2004). For most target species, effects of competitor species will be different if their functional traits are sufficiently different (Canham et al. 2006). Our study is among the first that obtained evidence for a species-specific neighbourhood effect on the current wood increment rate of a target species in natural forests (compare Bonn 1998; DeClerck et al. 2006). When testing for neighbour identity effects in the growth of a beech target tree, we found differences and similarities in the size and direction of neighbour effects for Tilia, Fraxinus, Quercus and Acer. Significant positive effects on mean Fagus increment and a reduced ring-series sensitivity in the period 1986-2005 were observed for Tilia, Fraxinus and Acer neighbourhoods, but not for those of Quercus. In contrast, beeches in neighbourhood of oaks recovered faster from the 1992 
negative pointer year but not with other neighbours. The gap fraction in the tree cluster was larger when Acer trees were present, and beeches grew bigger crowns in the neighbourhood of Tilia trees as compared to beeches in conspecific neighbourhood, but not in the neighbourhood of Fraxinus or Quercus. We conclude that tree-species identity, at least in some cases, matters for the magnitude and direction of the neighbourhood effect on beech growth.

\section{CONCLUSIONS}

In the species-rich temperate mixed forests of this study, we found a significant influence of tree neighbourhood on the radial increment of Fagus sylvatica and its sensitivity to environmental fluctuations. The observed effects were partly depending on the species identity of the neighbouring trees. Tree diversity in the neighbourhood apparently influenced beech growth sensitivity but not mean stem growth rate, pointing to a minor role of diversity itself on beech growth patterns.

\section{Acknowledgements}

We are grateful to Philippe Marchand for taking hemispheric photos, Laura Rose for support in crossdating tree-ring series, Hanns Hubert Leuschner for his advice and support in tree-ring analysis and various helpers for stem coring. The study was funded by the German Research Foundation (DFG) within the Research Training Group 1086. 


\section{References}

Amoroso, M.M., Turnblom, E.C., 2006. Comparing productivity of pure and mixed Douglas-fir and western hemlock plantations in the Pacific Northwest. Can. J. For. Res. 36, 1484-1496.

Assmann, E., 1970. The Principles of Forest Yield Study: Studies in the Organic Production, Structure, Increment and Yield of Forest Stands. Pergamon Press, Oxford.

Badeau, V., Dupouey, J.L., Becker, M., Picard, J.F., 1995. Long-term growth trends of Fagus sylvatica $L$ in northeastern France. A comparison between high and low density stands. Acta Oecol. 16, $571-583$.

Baillie, M.G.L., Pilcher, J.R., 1973. A simple crossdating program for tree-ring research. Tree-ring Bull. 33, 7-14.

Bauhus, J., van Winden, A.P., Nicotra, A.B., 2004. Aboveground interactions and productivity in mixed-species plantations of Acacia mearnsii and Eucalyptus globulus. Can. J. For. Res. 34, 686-694.

Bohdanecký, J., 1926. Zur Frage der Erziehung junger Fichtenbestände. Forstwiss. Cent.bl. 48, 777783.

Bonn, S., 1998. Dendroökologische Untersuchung der Konkurrenzdynamik in Buchen/EichenMischbeständen und zu erwartende Modifikationen durch Klimaänderungen. Contr. For. Sc. 3, $1-226$.

Brooker, R.W., Maestre, F.T., Callaway, R.M., Lortie, C.L., Cavieres, L.A., Kunstler, G., Liancourt, P., Tielbörger, K., Travis, J.M.J., Anthelme, F., Armas, C., Coll, L., Corcket, E., Delzon, S., Forey, E., Kikvidze, Z., Olofsson, J., Pugnaire, F., Quiroz, C.L., Saccone, P., Schiffers, K., Seifan, M., Touzard, B., Michalet, R., 2008. Facilitation in plant communities: the past, the present, and the future. J. Ecol. 96, 18-34.

Cahill, J.F., Casper, B.B., 2000. Investigating the relationship between neighbor root biomass and belowground competition: field evidence for symmetric competition belowground. Oikos 90, 311 320.

Callaway, R.M., 1995. Positive interactions among plants. Bot. Rev. 61, 306-349.

Canham, C.D., LePage, P.T., Coates, K.D., 2004. A neighborhood analysis of canopy tree competition: effects of shading versus crowding. Can. J. For. Res. 34, 778-787.

Canham, C.D., Papaik, M.J., Uriarte, M., McWilliams, W.H., Jenkins, J.C., Twery, M.J., 2006. Neighborhood analyses of canopy tree competition along environmental gradients in New England forests. Ecol. Appl. 16, 540-554.

Chen, H.Y.H., Klinka, K., Mathey, A.H., Wang, X., Varga, P., Chourmouzis, C., 2003. Are mixedspecies stands more productive than single-species stands: an empirical test of three forest types in British Columbia and Alberta. Can. J. For. Res. 33, 1227-1237.

Ciais, P., Reichstein, M., Viovy, N., Granier, A., Ogee, J., Allard, V., Aubinet, M., Buchmann, N., Bernhofer, C., Carrara, A., Chevallier, F., De Noblet, N., Friend, A.D., Friedlingstein, P., Grunwald, T., Heinesch, B., Keronen, P., Knohl, A., Krinner, G., Loustau, D., Manca, G., Matteucci, G., Miglietta, F., Ourcival, J.M., Papale, D., Pilegaard, K., Rambal, S., Seufert, G., Soussana, J.F., Sanz, M.J., Schulze, E.D., Vesala, T., Valentini, R., 2005. Europe-wide reduction in primary productivity caused by the heat and drought in 2003 . Nature 437, 529-533.

DeClerck, F.A.J., Barbour, M.G., Sawyer, J.O., 2006. Species richness and stand stability in conifer forests of the Sierra Nevada. Ecology 87, 2787-2799. 
Eckstein, D., Bauch, J., 1969. Beitrag zur Rationalisierung eines dendrochronologischen Verfahrens und zur Analyse seiner Aussagesicherheit. Forstwiss. Cent.bl. 88, 230-250.

Ellenberg, H., Leuschner, C., in press. Vegetation Mitteleuropas mit den Alpen, 6. ed. Ulmer, Stuttgart.

Frech, A., 2006. Walddynamik in Mischwäldern des Nationalparks Hainich - Untersuchung der Mechanismen und Prognose der Waldentwicklung. Ber. Forsch.zent. Waldökosyst. (A) 196, 1120.

Fritts, H.C., 2001. Tree rings and climate. Blackburn Press, Caldwell.

Gebauer, T., Horna, V., Leuschner, C., 2008. Variability in radial sap flux density patterns and sapwood area among seven co-occurring temperate broad-leaved tree species. Tree Physiol. 28, $1821-1830$.

Getzin, S., Dean, C., He, F., Trofymow, J.A., Wiegand, K., Wiegand, T., 2006. Spatial patterns and competition of tree species in a Douglas-fir chronosequence on Vancouver Island. Ecology 29, 671-682.

Gouveia, A.C., Freitas, H., 2008. Intraspecific competition and water use efficiency in Quercus suber: evidence of an optimum tree density? Trees 22, 521-530.

Grissino-Mayer, H.D., Kaennel Dobbertin, M., 2003. Dendrochronology Species Database. Names of tree and shrub species for which tree rings have been analysed in the published literature. Eidg. Forschungsanstalt WSL, Birmensdorf.

Hegyi, F., 1974. A simulation model for managing jack-pine stands, in: Fries, J. (Ed.), Growth Models for Tree and Stand Simulation. Royal College of Forestry, Stockholm, pp. 74-90.

Hertel, D., Leuschner, C., 2006. The in situ root chamber: A novel tool for the experimental analysis of root competition in forest soils. Pedobiologia 50, 217-224.

Hollstein, E., 1980. Mitteleuropäische Eichenchronologie: Trierer dendrochronologische Forschungen zur Archäologie und Kunstgeschichte. von Zabern, Mainz.

Jacob, M., Leuschner, C., Thomas, F.M., 2010. Productivity of temperate broad-leaved forest stands differing in tree species diversity. Annals of Forest Science 67, 503.

Jacob, M., Weland, N., Platner, C., Schaefer, M., Leuschner, C., Thomas, F.M., 2009. Nutrient release from decomposing leaf litter of temperate deciduous forest trees along a gradient of increasing tree species diversity. Soil Biol. Biochem. 41, 2122-2130.

Jactel, H., Brockerhoff, E., Duelli, P., 2005. A test of the biodiversity-stability theory: meta-analysis of tree species diversity effects on insect pest infestations and re-examination of responsible factors, in: Scherer-Lorenzen, M., Körner, C., Schulze, E. (Eds.), Forest Diversity and Function Temperate and Boreal Systems, Ecological Studies. Springer, Berlin Heidelberg New York, pp. 235-262.

Köcher, P., Gebauer, T., Horna, V., Leuschner, C., 2009. Leaf water status and stem xylem flux in relation to soil drought in five temperate broad-leaved tree species with contrasting water use strategies. Ann. For. Sci. 66, 101.

Lang, C., 2008. Diversität der Ektomykorrhizen in verschieden artenreichen Laubbaumbeständen im Nationalpark Hainich, Göttinger Forstwissenschaften 1. Universitätsverlag Göttingen, Göttingen.

Leuschner, C., Jungkunst, H.F., Fleck, S., 2009. Functional role of forest diversity: Pros and cons of synthetic stands and across-site comparisons in established forests. Basic Appl. Ecol. 10, 1-9.

Leuschner, H.H., Sass-Klaassen, U., Jansma, E., Baillie, M.G.L., Spurk, M., 2002. Subfossil European bog oaks: population dynamics and long-term growth depressions as indicators of changes in the Holocene hydro-regime and climate. Holocene 12, 695-706. 
Mailly, D., Turbis, S., Pothier, D., 2003. Predicting basal area increment in a spatially explicit, individual tree model: a test of competition measures with black spruce. Can. J. For. Res. 33, 435-443.

Man, R., Lieffers, V.J., 1999. Are mixtures of aspen and white spruce more productive than single species stands? For. Chron. 75, 505-513.

Meinen, C., 2008. Fine root dynamics in broad-leaved deciduous forest stands differing in tree species diversity. Dissertation, Niedersächsische Staats- und Universitätsbibliothek Göttingen, Göttingen.

Mölder, A., Bernhardt-Römermann, M., Schmidt, W., 2008. Herb-layer diversity in deciduous forests: Raised by tree richness or beaten by beech? For. Ecol. Manage. 256, 272-281.

Müller, A., 2007. Jahrringanalytische Untersuchungen zum Informationsgehalt von HolzkohleRückständen der historischen Meilerköhlerei. Dissertation, University of Freiburg (Breisgau), Freiburg (Breisgau).

Nakashizuka, T., Ishizuka, M., Ohkochi, I., 2002. General conclusion: Forest community Ecology and Applications, in: Diversity and Interaction in a Temperate Forest Community: Ogawa Forest Reserve of Japan, Ecological Studies. Springer-Verlag, Tokyo, pp. 301-312.

Oliver, C.D., Larson, B.C., 1990. Forest stand dynamics. McGraw-Hill, New York.

Pedersen, B.S., 1998. The role of stress in the mortality of midwestern oaks as indicated by growth prior to death. Ecology 79, 79-93.

Piotto, D., Víquez, E., Montagnini, F., Kanninen, M., 2004. Pure and mixed forest plantations with native species of the dry tropics of Costa Rica: a comparison of growth and productivity. For. Ecol. Manage. 190, 359-372.

Piutti, E., Cescatti, A., 1997. A quantitative analysis of the interactions between climatic response and intraspecific competition in European beech. Can. J. For. Res. 27, 277-284.

Plauborg, K.U., 2004. Analysis of radial growth responses to changes in stand density for four tree species. For. Ecol. Manage. 188, 65-75.

Podlaski, R., 2002. Radial growth trends of fir (Abies alba Mill.), beech (Fagus sylvatica L.) and pine (Pinus sylvestris L.) in the Świętokrzyski National Park (Poland). J. Forest Sci. 48, 377-387.

Pretzsch, H., 1995. Zum Einfluss der Baumverteilungsmusters auf den Bestandeszuwachs. Allg. Forst- Jagdztg. 166, 190-201.

Pretzsch, H., Schütze, G., 2009. Transgressive overyielding in mixed compared with pure stands of Norway spruce and European beech in Central Europe: evidence on stand level and explanation on individual tree level. Eur. J. For. Res. 128, 183-204.

Rewald, B., 2008. Impact of climate change-induced drought on tree root hydraulic properties and competition belowground. Dissertation, Niedersächsische Staats- und Universitätsbibliothek Göttingen, Göttingen.

Riemer, T., 1994. Über die Varianz von Jahrringbreiten. Statistische Methoden für die Auswertung der jährlichen Dickenzuwächse von Bäumen unter sich ändernden Lebensbedingungen. Berichte des Forschungszentrums Waldökosysteme (Reihe A) 121, 1-375.

Rothe, A., Binkley, D., 2001. Nutritional interactions in mixed species forests: a synthesis. Canadian Journal of Forest Research 31, 1855-1870.

Schmidt, I., Leuschner, C., Mölder, A., Schmidt, W., 2009. Structure and composition of the seed bank in monospecific and tree species-rich temperate broad-leaved forests. For. Ecol. Manage. 257, 695-702. 
Schwinning, S., 1996. Decomposition Analysis of Competitive Symmetry and Size Structure Dynamics. Ann. Appl. Biol. 77, 47-58.

Schwinning, S., Weiner, J., 1998. Mechanisms determining the degree of size asymmetry in competition among plants. Oecologia 113, 447-455.

Seebach, C.V., 1845. Der modifizierte Buchen-Hochwaldbetrieb. Kritische Blätter für Forst- und Jagdwissenschaft in Verbindung mit mehrern Forstmännern und Gelehrten 21, 147-185.

Sobek, S., 2008. Spatiotemporal patterns of insect diversity and multitrophic interactions across a tree diversity gradient in a Central European deciduous forest. Dissertation, Niedersächsische Staats- und Universitätsbibliothek Göttingen, Göttingen.

Tilman, D., 2004. Niche tradeoffs, neutrality, and community structure: A stochastic theory of resource competition, invasion, and community assembly. Proc. Natl. Acad. Sci. U.S.A. 101, 1085410861.

Tome, M., Burkhart, H.E., 1989. Distance-dependent competition measures for predicting growth of individual trees. For. Sci. 35, 816-831.

Vacek, S., Lepš, J., 1996. Spatial dynamics of forest decline: The role of neighbouring trees. J. Veg. Sci. 7, 789-798.

Weber, P., Bugmann, H., Fonti, P., Rigling, A., 2008. Using a retrospective dynamic competition index to reconstruct forest succession. For. Ecol. Manage. 254, 96-106.

Wettberg, E.V., Weiner, J., 2003. Larger Triticum aestivum plants do not preempt nutrient-rich patches in a glasshouse experiment. Plant Ecol. 169, 85-92.

Wulf, M., 2003. Preference of plant species for woodlands with differing habitat continuities. Flora 198, 444-460.

Yoshida, T., Kamitani, T., 2000. Interspecific competition among three canopy-tree species in a mixedspecies even-aged forest of central Japan. For. Ecol. Manage. 137, 221-230. 
Chapter 4

\author{
$\delta^{13} \mathrm{C}$ signature of tree rings and radial \\ increment of Fagus sylvatica trees as \\ dependent on tree neighborhood and climate
}




\title{
$\delta^{13} \mathrm{C}$ signature of tree rings and radial increment of Fagus sylvatica trees as dependent on tree neighborhood and climate
}

Inga Mölder, Christoph Leuschner, Hanns Hubert Leuschner

\begin{abstract}
We conducted dendroecological analyses in 80-yr-long tree ring chronologies to detect neighborhood effects (competition intensity, species identity) on the $\delta^{13} \mathrm{C}$ signature of tree rings and radial stem increment of Fagus sylvatica trees growing either in monospecific or mixed patches of a temperate forest. We hypothesized that tree ring $\delta^{13} \mathrm{C}$ is a more sensitive indicator of neighborhood effects and climate variability on growth than is ring width. We found a closer correlation of summer precipitation to $\delta^{13} \mathrm{C}$ than to ring width. While ring width showed a decline over the test period (1926-2005), the mean curve of $\delta^{13} \mathrm{C}$ increased until the mid of the 1970s, remained high until about 1990, and markedly decreased thereafter. Possible explanations related to ontogeny and environmental change ('age effect' due to canopy closure; elevated atmospheric $\mathrm{SO}_{2}$ concentrations in the 1960s-1980s) are discussed. Beech target trees surrounded by many allospecific trees had a significantly lower mean $\delta^{13} \mathrm{C}$ in the period 1926-1975 than beech with predominantly or exclusively conspecific neighborhood, possibly indicating a more favorable water supply of beech in diverse stands. Contrary to expectation, trees subject to more intense competition by neighboring trees (measured by Hegyi's competition index) had lower $\delta^{13} \mathrm{C}$ values in their tree rings, which is thought to reflect denser canopies being linked to increased shading. We conclude that tree ring $\delta^{13} \mathrm{C}$ time series represent combined archives of climate variability, stand history and neighborhood effects on tree physiology and growth that may add valuable information to that obtained from conventional tree ring analysis.
\end{abstract}

Key-words: allospecific neighbor $\cdot$ cambial age $\cdot$ conspecific neighbor $\cdot$ dendrochronology $\bullet$ forest management $\cdot$ mixed stand 


\section{Introduction}

One important issue in the biodiversity - ecosystem functioning debate is the dependence of ecosystem stability on diversity (Odum 1953; Loreau et al. 2002; DeClerck et al. 2006). Frequently discussed stability parameters of ecosystems are the resistance to, and the resilience after, disturbances such as drought events or herbivore attack. Most of the relevant research on the relationship between diversity and stability has been conducted in herbaceous plant communities while woody associations have been studied only exceptionally. It is generally accepted that mixed forests show greater resilience with regard to herbivore attack than monospecific stands (Jactel 2005; Pretzsch 2005). However, the relationship between tree species diversity and the resistance to, or the resilience after, drought events in forests is not clear yet (Larsen 1995; DeClerck et al. 2006). This question is of high relevance to forestry because natural forests are widely being replaced by monospecific plantations in temperate and in tropical regions while the consequences for ecosystem functioning and stability are poorly known.

Common reactions of trees to water limitation are reductions in height and diameter growth, which can last for several years or even decades (Peterken and Mountford 1996; Archaux and Wolters 2006; Bréda et al. 2006). Drought effects in forests can be enhanced by intraspecific or interspecific competition for water (Gouveia and Freitas 2008) which may be reflected in the chronology of annual tree rings (Saurer et al. 2008). Another archive of environmental changes is the tree-ring $\delta^{13} \mathrm{C}$ signature. It can be used as a proxy for stomatal conductance and thus as a tool for obtaining a longterm record of changes in soil moisture and/or the evaporative demand of trees. $\delta^{13} \mathrm{C}$ values of tree rings have been reported to show drought signals more precisely than tree-ring width does (Andreu et al. 2008). In a similar manner as tree rings, $\delta^{13} \mathrm{C}$ time series do not represent pure physical archives but may also reflect biological processes such as competition for light or water in the forest stand.

The intensity of interspecific or intraspecific competition in forests is often approximated by indices of stand density such has Hegyi's competition index which is based on stem distance and diameter (Orwig and Abrams 1997; Piutti and Cescatti 1997; Gouveia and Freitas 2008). For most of the investigated mixed forest stands, interspecific competition between different tree species has been reported to be asymmetric (Yoshida and Kamitani 2000; Canham et al. 2004; Canham et al. 2006). This can alter the water availability in the stand with consequences for tree growth and the $\delta^{13} \mathrm{C}$ signature in the annual rings of the present species. Aboveground competition may also result in changes of the canopy structure and the light regime, thereby affecting the $\delta^{13} \mathrm{C}$ signature of leaf mass (Medina et al. 1991; Buchmann et al. 1997; Hanba et al. 1997; West et al. 2001). These relationships make it probable to detect effects of competition in the stem wood $\delta^{13} \mathrm{C}$ signal as well. Further, niche complementarity can reduce the intensity of interspecific competition in comparison with intraspecific competition (Kelty 2006). As a consequence, positive effects on growth and water status of one or more partners of the interaction may occur. Thus, long-term records of these growth and water status proxies can provide valuable insight into a tree's long-term water regime and possibly also into competition-induced changes of the water balance (McNulty and Swank 1995; Buchmann et al. 1997; Skomarkova et al. 2006; Grams et al. 2007; Saurer et al. 2008). 
For a time series of 80 years, we analyzed the radial increment and the $\delta^{13} \mathrm{C}$ signature of tree rings of selected Fagus sylvatica trees. These trees were carefully selected for their specific neighborhood constellations and competition intensity in monospecific and mixed patches of a species-rich temperate deciduous forest. Our study tests two hypotheses, i) the $\delta^{13} \mathrm{C}$ signature in tree rings is influenced by the competition intensity and the species identity of a tree's neighborhood, and ii) tree ring $\delta^{13} \mathrm{C}$ signatures are more sensitive indicators of neighborhood effects and climate variation than tree ring series are.

\section{Methods}

\section{STUDY SITE}

Dendrochronological and dendrochemical investigations were conducted in 16 mature Fagus sylvatica L. (European beech) trees in the temperate broad-leaved forests of Hainich National Park (western Thuringia, Central Germany) close to the village of Weberstedt (5105'28'N, 1031'24'E) at about $350 \mathrm{~m}$ elevation. Besides the Galio-Fagetum and the Hordelymo-Fagetum associations, i.e. beech forests on slightly acidic to basic soils, the Stellario-Carpinetum community, a broad-leaved mixed forest rich in hornbeam, linden and ash (Mölder et al. 2008; 2009), is abundant in the study region. The most common tree species are Fagus sylvatica, Fraxinus excelsior L. (European ash) and Tilia cordata Mill. (little-leaved linden), whereas T. platyphyllos Scop. (large-leaved linden), Carpinus betulus L. (European hornbeam) and Acer pseudoplatanus L. (Sycamore maple) are admixed at lower densities.

The trees were chosen at a maximum distance to each other of $4.9 \mathrm{~km}$ on eutrophic loessderived soils with a profile depth of about $60 \mathrm{~cm}$, situated in level or gently sloping terrain on limestone (Triassic Upper Muschelkalk). The soil type of the study sites is (stagnic) Luvisol according to the World Reference Base for Soil Resources (FAO/ISRIC/ISSS 1998). Since the forest exists for at least 200 years, it represents ancient woodland in the definition of Wulf (2003). During the past 40 years, only single stems have been extracted. The last extractions of stems were conducted on the study sites between 1991 and 1998 (pers. communication E. Kinne). All trees were selected in stand sections with a closed canopy and a more or less homogenous stand structure. The recent investigation is part of the Hainich Tree Diversity Matrix Study, which analyzes the functional role of tree diversity in a temperate mixed forest (Leuschner et al. 2009). We conducted soil chemical and physical surveys on all prospective study sites prior to tree selection in order to guarantee sufficient site comparability with respect to edaphic conditions. The study area is characterized by an annual mean temperature of $7.5^{\circ} \mathrm{C}$ and about $590 \mathrm{~mm}$ precipitation per year (1973-2004, Deutscher Wetterdienst Offenbach, Germany). 


\section{TREE SELECTION AND NEIGHBORHOOD CHARACTERIZATION}

For investigating radial increment and the $\delta^{13} \mathrm{C}$ signature in annual rings of beech in its dependence on variable stem neighborhoods, we selected 16 trees from a pool of 152 adult Fagus trees, which had been analyzed for tree ring chronologies in a precedent study (Mölder and Leuschner, see Chapter 3). Tree selection bases on pre-defined criteria of the neighborhood constellation. All target Fagus trees were part of the upper canopy and had a diameter at breast height (dbh) of 40 to $60 \mathrm{~cm}$. In the direct neighborhood of these trees, we recorded the species identity, dbh, height and relative position (i.e. distance and angle between neighbor and target tree) of those trees $>7 \mathrm{~cm}$ dbh whose crowns had direct contact with the beech target tree. The 16 chosen tree groups consisted of three to five (in a few cases: up to eight) trees surrounding the beech target tree and covered stand areas of about 100 to $600 \mathrm{~m}^{2}$ in size. In winter 2006/2007, dbh, tree height and species composition were recorded in the tree clusters with the aim to characterize the neighborhood of the beech target trees qualitatively and quantitatively. We also quantified the crown dimensions by 8-point crown projections using a sighting tube equipped with a $45^{\circ}$ mirror an d cross-hairs to ensure the proper view of canopy elements from the ground (Johansson 1985). For approximating the projected crown area by a polygon, eight points along the edge line of the crown were selected in a manner that approximated the estimated crown area best. In summer 2007, hemispheric photos were taken with a digital camera equipped with a fisheye lens, thus providing information on canopy dimensions, gap fraction and canopy openness in the neighborhood of the central beech tree. To calculate canopy openness, we used the software Gap Light Analyzer 2.0 (Simon Fraser University, British Columbia, Canada \& Institute of Ecosystem Studies, New York, USA) and restricted the canopy perspective to an opening angle of $30^{\circ}$ from the zenith which is in agreement with the protocol for analyzing tree competition in forests applied by Pretzsch (1995). We calculated the coefficient of variation (CV) of tree height in the tree clusters in order to provide a measure of canopy heterogeneity. To estimate the intensity of competition in the tree clusters, we calculated the competition index $\mathrm{Cl}$ after Hegyi (1974) for all those trees in the neighborhood of the target beech tree that were present with a part of their crown in the "influence sphere" of this tree, i.e. a cone with an angle of $60^{\circ}$ turned upside down with the apex being positioned at $60 \%$ of the target tree's height. The more trees being present in this cone and the smaller the distance to the target tree, the higher is the competition index:

$$
C I_{i}=\sum_{j=1}^{n} \frac{d_{j} / d_{i}}{D i s t_{i j}}
$$

where $d_{i}$ is the diameter at breast height of the target tree $i(\mathrm{~cm}) ; d_{j}$ is the diameter at breast height of the competitor $\mathrm{j}(\mathrm{cm})$; and Dist $_{\mathrm{ij}}$ is the distance between target tree and competitor $(\mathrm{m})$. Trees with a competition index larger than 0.9 were classified as trees exposed to higher competition intensity $(n=$ 8), target trees with a $\mathrm{Cl}$ smaller than 0.9 as trees with lower competition intensity $(n=8)$. 
We further expressed the tree diversity of the clusters with the Shannon diversity index H' (Magurran 2004):

$$
H^{\prime}=-\sum_{i=1}^{S} p_{i} \ln p_{i} \text { with } p_{i}=\frac{n_{i}}{N}
$$

where $S$ is the species richness of the target tree's neighborhood and $p_{i}$ is the fraction of trees belonging to species $i$. The fraction $p_{i}$ is calculated from the ratio between the number of stems $n_{i}$ of species $\mathrm{i}$ and the total number of neighbors $\mathrm{N}$.

Subsequently, we grouped the clusters according to the importance of Fagus and non-Fagus trees in the neighborhood (all neighbors being Fagus: Fagus100 group, 70 to $99 \%$ of the competition index value being contributed by Fagus-Fagus interactions: Fagus70-99 group, less than $70 \%$ of the $\mathrm{Cl}$ value being due to Fagus-Fagus interaction but more than $30 \%$ being due to allospecific interactions: Fagus $<70$ group). Allospecific neighbors belonged to the genera Tilia, Fraxinus, Quercus and Acer.

From the sample of 152 beech trees used for dendrochronological research, we selected the beech target trees for the neighborhood analysis according to the following criteria: The ring series could be successfully cross-dated to stand chronologies and no questionable tree rings occurred, the crown area was at least $30 \mathrm{~m}^{2}$, the time period between sample extraction, ring measurement and sample drying was not longer than one or two days, and the samples were free from signs of injury or infection. This selection procedure reduced the sample size to 16 target trees to be considered; the three neighborhood groups contained four (Fagus100), five (Fagus70-99) and seven (Fagus $<70$ ) target trees. The four to seven trees were treated as replicates in the analysis. Even though we ended up with a rather small number of suitable trees in each group, we preferred to apply these strict selection criteria to obtain beech trees with a well defined neighborhood and to do the analysis with rather homogenous data sets in terms of neighborhood structure, instead of including possible further target trees with somewhat different neighborhoods which would have increased the data heterogeneity. We accepted that the smallest sample size $(n=4)$ was realized in the group with exclusively intraspecific neighborhood (Fagus100) because these tree clusters were more homogenous than the Fagus70-99 and Fagus $<70$ groups with a variable species identity of the neighbors and, thus, a more heterogeneous structure of the neighborhood.

\section{SAMPLE PREPARATION AND ANALYSIS}

In summer 2006, we cored all 16 Fagus target trees at $1.3 \mathrm{~m}$ height ( $5 \mathrm{~mm}$ corer) on that side of the trunk that showed lowest influence of wood tension or compression. Since we had to meet the conservation regulations of the Hainich National Park, each tree was cored only once. After recutting the surface of the cores with a razor blade, we used titanium dioxide to enhance the visibility of the tree rings before ring analysis. Annual tree-ring width was measured to the nearest $0.01 \mathrm{~mm}$ using a 
LINTAB-5 dendrochronological measuring table (Rinn Tech, Heidelberg, Germany) and TSAPSoftware (TSAP-Win Version 0.59 for Microsoft Windows, Rinn Tech, Heidelberg, Germany). In a preanalysis, we searched for unrecognizable or questionable rings in the cores in order to reconsider them during cross-dating. As quality criteria, we considered the t-value (Baillie and Pilcher 1973; Hollstein 1980), the co-linearity of increment (Gleichläufigkeit, Eckstein and Bauch 1969), and the cross-dating index (Grissino-Mayer and Kaennel Dobbertin 2003). Cross-dating of a chronology was accepted as being reliable, when it reached a minimum t-value of 3.5 (Baillie and Pilcher 1973; Hollstein 1980), a minimum co-linearity of $70 \%$ for a 50-yr overlap (Eckstein and Bauch 1969; Frech 2006), and a minimum cross-dating-index (CDI) > 20 (Müller 2007). The tree age for the coring height $(1.3 \mathrm{~m})$ was calculated as follows: We took pictures from the core centers and determined the distance between the innermost visible tree ring and the point of intersection of the medullary rays. The distance was then divided by the mean ring width of the ten innermost rings to estimate the number of missed tree rings, which were then added to the number of measured tree rings (Schmidt et al. 2009). Subsequent to the dendrochronological analysis, the samples were dried at $65^{\circ} \mathrm{C}$ and cut ring by ring for the period 1926 to 2005 . Both the latewood and earlywood of a ring were included in the samples in order to reduce the variation caused by anatomical properties (Smith and Shortle 1996). The wood of a tree ring was cut into small pieces with a razor blade and $1 \mathrm{mg}$ of a ring was weighed out in tin capsules for determination of the $\delta^{13} \mathrm{C}$ signature. We used samples of 0.4 to $1 \mathrm{mg}$ of acetanilide as internal standard. The analyses were carried out with a Delta $\vee$ Advantage isotope ratio mass spectrometer (Thermo Fisher Scientific, Waltham, Massachusetts, U.S.A.), which was combined with a Conflo III interface (Thermo Fisher Scientific) and a NA $1500 \mathrm{C} / \mathrm{N}$ Elementar Analyzer (Carlo Erba Strumentazione, Milan, Italy). By using the internal standard acetanilide, the ${ }^{12} \mathrm{C} /{ }^{13} \mathrm{C}$ isotope ratios were related to the Peedee belemnite limestone standard using the equation $\delta^{13} \mathrm{C}(\%)=$ $\left(\left[R_{\text {sample }} / R_{\text {standard }}\right]-1\right) \times 1000$, with $\mathrm{R}={ }^{13} \mathrm{C} / /^{12} \mathrm{C}$. Partial stomatal closure may be indicated by an enrichment of ${ }^{13} \mathrm{C}$, i.e. higher (less negative) values of $\delta^{13} \mathrm{C}$.

\section{STATISTICAL METHODS}

Individual ring-width series were standardized following mainly Andreu et al. (2008). After a Box-Cox transformation of the raw width values (in $\mathrm{mm}$ ) to stabilize the variance, we detrended the series by fitting a linear regression line. Subsequently, standard chronologies were built with robust means. Furthermore, we removed autocorrelation from the single detrended ring series by using an autoregressive model. $\delta^{13} \mathrm{C}$ values were first corrected for long-term changes in the atmospheric ${ }^{13} \mathrm{CO}_{2}$ signal by addition of the difference between modeled atmospheric $\delta^{13} \mathrm{C}$ and a standard value $\left(\delta^{13} \mathrm{C}_{\text {cor }}\right)$. As standard we used the "pre-industrial" atmospheric $\delta^{13} \mathrm{C}$ of $-6.4 \%$ as suggested by McCarroll and Loader (2004). Subsequently, we applied an autoregressive model in order to remove autocorrelation in the $\delta^{13} \mathrm{C}_{\text {cor }}$ time series as was done in the ring width series (wca). In the following, the $\delta^{13} \mathrm{C}_{\text {cor }}$ time series corrected for autocorrelation will be referred to as $\delta^{13} \mathrm{C}_{\mathrm{ac}}$. 
Descriptive statistics on ring-width series and $\delta^{13} \mathrm{C}$ chronologies were calculated with the package dpIR, yielding mean sensitivity according to equation $3\left(\mathrm{MS}_{\mathrm{I}}\right)$ and equation $4\left(\mathrm{MS}_{\|}\right)$after Biondi and Qeadan (2008). $\mathrm{MS}_{\|}$takes present trends into account and gives with its absolute value, in a similar way as $\mathrm{MS}_{\mathrm{l}}$, a measure for temporal dissimilarity:

$$
M S_{I}=\frac{2}{n-1} \sum_{t=2}^{n} \frac{\left|w_{t}-w_{t-1}\right|}{w_{t}+w_{t-1}}
$$

$M S_{I I}=\frac{n}{n-1} \frac{\sum_{t=2}^{n}\left|w_{t}-w_{t-1}\right|}{\sum_{t=1}^{n} w_{t}}$

with $\mathrm{w}=$ width of the tree ring, $\mathrm{n}=$ length of the tree-ring series, $t=1,2, \ldots, \mathrm{n}=$ years in the tree-ring series.

Tests for differences in absolute stem increment and $\delta^{13} \mathrm{C}$ signatures among beech trees of different neighborhood categories were conducted with a non-parametric multiple comparison procedure after Hothorn et al. (2008), implemented for Dunnett-contrasts or, for two groups, with a two-sample test for the non-parametric Behrens-Fisher problem (Brunner and Munzel 2000). Significance was assumed for two-sided $p$-values $<0.05$. Differences between individual tree-ring series were tested for significance with Friedman's non-parametric test. For these statistical analyses, we used the software R (version 2.8.1, R Development Core Team, 2009) with the following packages and scripts: sarima, dpIR, nparcomp and zoo.

Climate (monthly precipitation and temperature) data were derived from the data set CRU TS 2.1 (Mitchell and Jones 2005). The sum of monthly totals of precipitation and averages of temperature for the period between January and December were used to build chronologies of whole-year climate data (hereafter referred to as annual values). We calculated a climate index as the quotient of the precipitation total and the mean temperature of the months April to September (Frech 2006). Bootstrapped Pearson correlations (number of bootstrapped iterations $=1000$ ) of monthly precipitation and temperature were calculated with the program DendroClim2002 (Biondi and Waikul 2004) for the year of tree-ring formation (current year) and the year prior to ring formation (preceding year). In order to avoid the problem of multi-colinearity, which would occur in data sets on meteorological parameters, we also calculated response functions (Fritts 1976). Correlation coefficients and response function coefficients are only indicated if they were significant at $p<0.05$. 


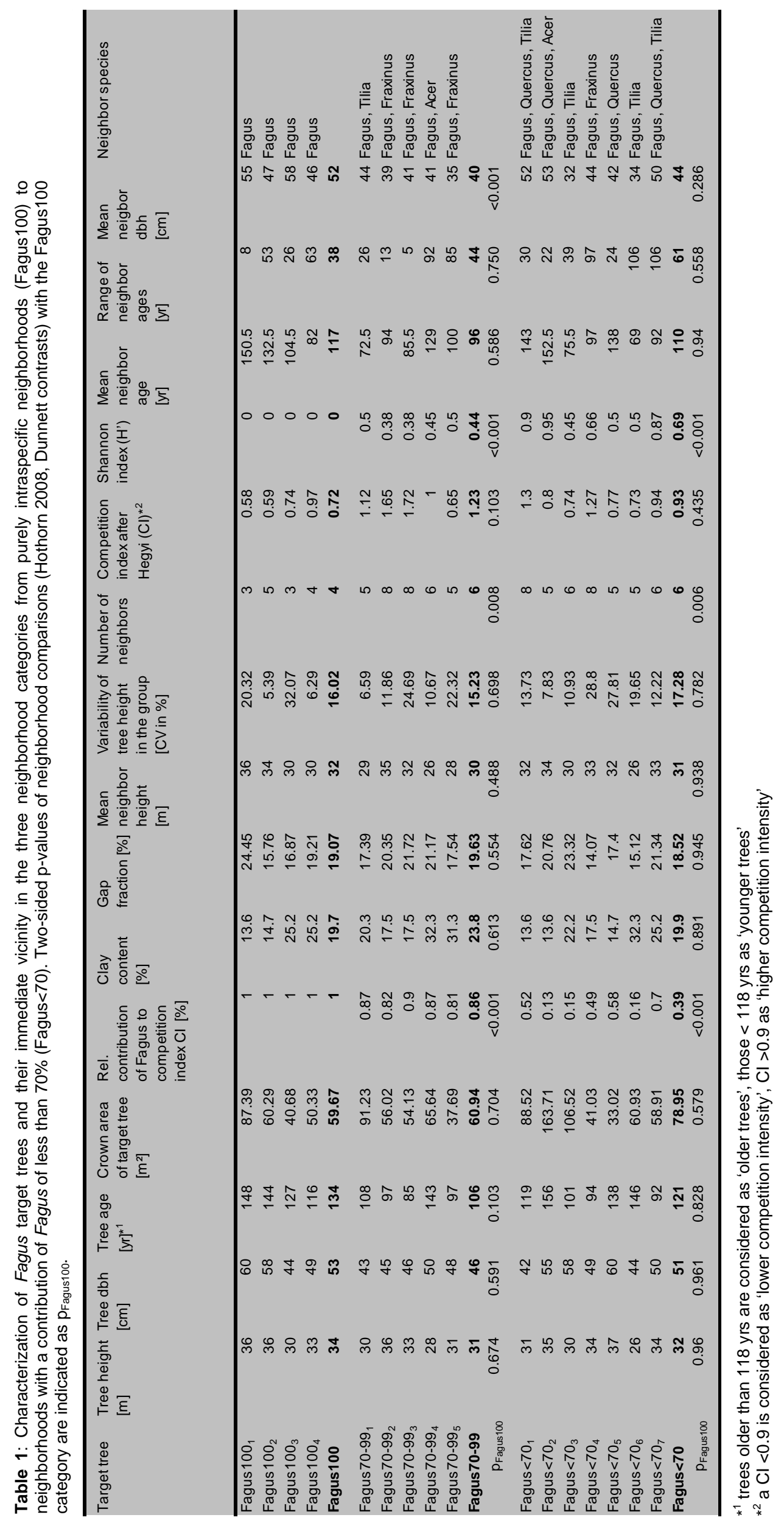


Table 2: Descriptive statistics for the 1926-2005 chronologies of raw ring-width series and $\delta^{13} \mathrm{C}_{\text {cor }}$ tree-ring chronologies of Fagus trees in three different neighborhoods (only conspecific neighbors: Fagus100, few allospecific neighbors, many Fagus neighbors: Fagus70-99, many allospecific and also Fagus neighbors: Fagus $<70$ ).

\begin{tabular}{|c|c|c|c|}
\hline & Fagus 100 & Fagus70-99 & Fagus $<70$ \\
\hline \multicolumn{4}{|l|}{ Ring-width series } \\
\hline Mean ring width $(1 / 100 \mathrm{~mm})^{*}$ & 233 & 243 & 236 \\
\hline Standard deviation & 89 & 108 & 96 \\
\hline Mean sensitivity I $\left(\mathrm{MS}_{\mathrm{I}}\right)$ & 0.28 & 0.3 & 0.28 \\
\hline Mean sensitivity II $\left(\mathrm{MS}_{\mathrm{II}}\right)$ & 0.25 & 0.26 & 0.25 \\
\hline First order autocorrelation & 0.61 & 0.64 & 0.63 \\
\hline \multicolumn{4}{|l|}{$\delta^{13} C_{c o r}$-chronology } \\
\hline Mean $\delta^{13} \mathrm{C}_{\mathrm{cor}}(\% \circ)^{*}$ & -24.03 & -24.66 & -24.92 \\
\hline Standard deviation & 1.2 & 1.33 & 1.26 \\
\hline First order autocorrelation & 0.59 & 0.58 & 0.64 \\
\hline
\end{tabular}

\section{Results}

\section{BEECH STEM INCREMENT AND $\delta{ }^{13} \mathrm{C}$ SIGNATURES AS DEPENDENT ON CLIMATIC PARAMETERS}

For our study site, neither annual values (precipitation, temperature and climate index) nor values for the growing season (April to September) revealed significant linear trends with the year as independent variable over the 80 -yr study period. However, we detected a significant linear increase of temperature in the growing season for the period after $1976\left(R^{2}{ }_{a d j}=0.48, p<0.001, y=0.087 x-\right.$ 160.183; $x=$ Gregorian year). In contrast, precipitation and climate index showed no trend for the period 1976-2005.

We detected both negative (July-September, bootstrapped correlation coefficients $r$ between -0.42 and -0.19 ) and positive (June and October, $r$ values between 0.21 and 0.40 ) correlations between ring-width chronologies (wca) and monthly mean temperatures during the growing season of the year prior to the reference year (Fig. 1c). Temperature values of the current year showed exclusively a negative correlation with ring width (June and July, $r$ values between -0.33 and -0.21 ). Response function coefficients for temperatures of the current year were only significant for June to July and were always negative. In contrast to the correlation analysis, the more rigorous response function coefficients were never significant for a given time period for the sampled trees in all three neighborhood groups (Fagus100, Fagus70-99 and Fagus $<70$ ).

Precipitation in June of the preceding year and ring width were negatively correlated (correlation coefficients between -0.30 and -0.24 ), while precipitation in the growing season of the current year was positively related to ring width ( $r$ values ranging from 0.20 to 0.33 ). The response function coefficient was only significant for the conspecific group Fagus 100 in June $(r=0.17)$. Precipitation was only a relevant factor for all neighborhoods in June of the preceding year. 
Monthly temperature values in the growing season (June to August) of the year prior to ring formation showed a significant negative correlation with the $\delta^{13} C_{a c}$ chronologies ( $r$ values between -0.28 and 0.20 ), while growing season temperature (June to August) of the current year was positively related to the $\delta^{13} \mathrm{C}_{\mathrm{ac}}$ signature $(\mathrm{r}: 0.21-0.29)$. All three neighborhood groups were similar in showing a relationship of $\delta^{13} \mathrm{C}_{\mathrm{ac}}$ to temperature in July, while the response function coefficients were not significant in any of the neighborhood groups in a given month. Only June precipitation of the current year was negatively correlated with the $\delta^{13} \mathrm{C}_{\mathrm{ac}}$ signature from all neighborhood groups ( $\mathrm{r}$ : -0.39 to -0.37) and the response function coefficients were significant and negative for all three neighborhoods as well.

\section{RELATIONSHIP BETWEEN $\delta^{13} \mathrm{C}$ SIGNALS AND ANNUAL RADIAL INCREMENT}

Whereas the $\delta^{13} \mathrm{C}_{\text {cor }}$ mean curve of all 16 sampled trees showed a continuous increase until the mid of the 1970s with a steep decline after about 1990, the increment curve generally declined over the 80 investigated years (Fig. 2). If we assume that increment and $\delta^{13} \mathrm{C}_{\text {cor }}$ signals should be negatively correlated, only six of the 16 sampled trees showed the assumed relationship for the period 1926 to 2005 with correlation coefficients between -0.42 and -0.24 (Table 3). Trees from all neighborhood groups equally showed a negative relationship between ring-width chronologies (wca) and $\delta^{13} \mathrm{C}_{\mathrm{ac}}$ series. Neither tree height, variability in tree height in the investigated tree cluster, or crown area, nor $\mathrm{Cl}$ showed significant effects on the direction of the correlation between wca and $\delta^{13} \mathrm{C}_{\mathrm{ac}}$ chronology (data not shown). In contrast, trees, where $\delta^{13} \mathrm{C}_{\mathrm{ac}}$ and annual increment were negatively correlated, were significantly younger ( $p=0.037$, two-sided) than trees not showing this negative relationship (Table 3, trees with a significant negative relationship in any of the analyzed periods vs. trees with no significant or a positive relationship). Moreover, younger trees generally revealed a closer and older trees a less tight $\delta^{13} \mathrm{C}_{a c}$-ring width relation. Further, the $\delta^{13} \mathrm{C}_{\mathrm{ac}}$-ring width relationship was different between the 1926-1975 and 1975-2005 periods for most of the sampled trees with only four trees showing a significant relationship between the two variables in the 1975-2005 period.

Table 3: Pearson correlation coefficients $(r)$ and $p$-values for relationships between radial increment and $\delta^{13} \mathrm{C}_{\mathrm{ac}}$. Tree age has been calculated as described in the text in cases the pith was not hit by coring. Negative correlations between radial increment and $\delta^{13} \mathrm{C}_{a c}$ chronology are printed bold.

\begin{tabular}{|c|c|c|c|c|c|c|c|}
\hline & \multirow[b]{2}{*}{ Tree age $[\mathrm{yr}]$} & \multicolumn{2}{|c|}{$1926-2005$} & \multicolumn{2}{|c|}{$1926-1975$} & \multicolumn{2}{|c|}{ 1976-2005 } \\
\hline & & $p$ & $r$ & $p$ & $r$ & $p$ & $r$ \\
\hline Fagus $100_{1}$ & 148 & 0.173 & -0.16 & 0.117 & -0.23 & 0.837 & -0.04 \\
\hline Fagus $100_{2}$ & 144 & 0.545 & 0.07 & 0.955 & -0.01 & 0.326 & 0.19 \\
\hline Fagus $100_{3}$ & 127 & 0.006 & -0.3 & 0.005 & -0.39 & 0.357 & -0.17 \\
\hline Fagus $100_{4}$ & 116 & 0.008 & -0.3 & 0.091 & -0.25 & 0.039 & -0.38 \\
\hline Fagus70-99 & 108 & 0.083 & 0.2 & 0.044 & 0.29 & 0.268 & 0.21 \\
\hline Fagus $70-99_{2}$ & 97 & 0.016 & 0.29 & 0.142 & 0.23 & 0.048 & 0.36 \\
\hline Fagus $70-99_{3}$ & 85 & 0.037 & -0.24 & 0.005 & -0.4 & 0.529 & -0.12 \\
\hline Fagus $70-99_{4}$ & 143 & 0.962 & -0.01 & 0.249 & -0.17 & 0.278 & 0.2 \\
\hline Fagus $70-99_{5}$ & 97 & 0.004 & -0.32 & $<0.001$ & -0.51 & 0.947 & -0.01 \\
\hline Fagus $<70_{1}$ & 119 & 0.144 & 0.17 & 0.007 & 0.38 & 0.223 & -0.23 \\
\hline Fagus $<70_{2}$ & 156 & 0.47 & 0.08 & 0.309 & 0.15 & 0.973 & -0.01 \\
\hline Fagus $<70_{3}$ & 101 & $<0.001$ & -0.42 & 0.007 & -0.41 & 0.005 & -0.49 \\
\hline Fagus $<70_{4}$ & 94 & 0.202 & -0.15 & 0.028 & -0.31 & 0.624 & 0.09 \\
\hline Fagus $<70_{5}$ & 138 & 0.925 & -0.01 & 0.259 & -0.17 & 0.408 & 0.16 \\
\hline Fagus $<70_{6}$ & 146 & 0.798 & 0.03 & 0.066 & 0.27 & 0.036 & -0.38 \\
\hline Fagus $<70_{7}$ & 92 & 0.015 & -0.27 & 0.003 & -0.43 & 0.685 & -0.08 \\
\hline
\end{tabular}




\section{BEECH STEM INCREMENT AND $\delta^{13} \mathrm{C}$ SIGNALS AS INFLUENCED BY COMPETITION INTENSITY AND NEIGHBORHOOD DIVERSITY}

Even though the differences in mean annual growth and $\delta^{13} \mathrm{C}_{\text {cor }}$ signature between Fagus trees with contrasting neighborhood diversity were not significant for the period 1976-2005 (Fig. 5), the plotted mean curves of the ring-width chronologies ranged at different height indicating a smaller increment since approximately 1976 for beech trees with predominantly conspecific neighborhood (Fig. 4). If trees from a purely conspecific neighborhood (Fagus100) and trees from a mainly conspecific neighborhood (Fagus70-99) are pooled, significantly lower $\delta^{13} \mathrm{C}_{\text {cor }}$ values appear in the allospecific neighborhood Fagus $<70$ than in the conspecific group (Fagus70 - 100) in the earlier period 1926-1975 $(p=0.045$, one-sided, Fig. 5). For the period 1976 to 2005, there was no significant difference between these groups ( $p=0.959$, two-sided). The higher radial increment of the Fagus $<70$ group in 1976 - 2005 was only marginally significant $(p=0.076$, one-sided), and there was no significant difference for the earlier period 1926-1975 ( $p=0.382$, two-sided). If the chronologies of individual trees are considered, comparison of $\delta^{13} \mathrm{C}_{\text {cor }}$ series from beeches in intraspecific neighborhoods with Fagus trees in allospecific neighborhoods revealed significant differences for most of the trees (Table 4). Three of the four trees in intraspecific neighborhood (Fagus $100_{1}$ to Fagus $100_{3}$ ) in most cases showed higher $\delta^{13} \mathrm{C}_{\text {cor }}$ values than the trees belonging to the Fagus70-99 and Fagus $<70$ group.

Analogous to comparisons between mainly conspecific neighborhoods and allospecific neighborhoods (Fig. 5), we grouped beech trees with regard to the competition intensity in the neighborhood according to Hegyi's index $\mathrm{Cl}$ (Fig. 6), irrespective of con- or allospecific interactions, and investigated the mean $\delta^{13} \mathrm{C}_{\text {cor }}$ values and mean radial increment for the two periods 1926-1975 and 1976-2005. Differences between $\delta^{13} \mathrm{C}_{\text {cor }}$ values of the two competition intensity groups were significant for the period 1976-2005 ( $p=0.014$, one-sided) and existed as a tendency for the earlier period 1926-1975 as well ( $p=0.09$, one-sided). Radial increment in the period 1926-1975 tended to be higher in the beech trees being subject to a higher competition intensity, but this difference was not significant ( $p=0.345$, two-sided; 1976-2005: $p=0.549$, two-sided). The competition index $\mathrm{Cl}$, which bases on distance and dbh of the neighbors, tended to be higher for the Fagus70-99 and Fagus $<70$ neighborhood categories than for the conspecific Fagus100 group (Table 1, differences not significant). Thus, competition intensity appeared to be higher in predominantly allospecific than conspecific tree neighborhoods. Trees exposed to lower competition intensity were on average older than trees with a higher competition index ( $p=0.01$, one-sided). 



Fig. 1: Bootstrapped correlations (bars, $r$ ) of $\delta^{13} \mathrm{C}_{\mathrm{ac}}$ and radial increment data (wca) with monthly precipitation and temperature values of the preceding and current year. In addition, the coefficients of response functions are given as horizontal lines (rf). Only significant correlations and response functions are shown $(p<0.05)$. 


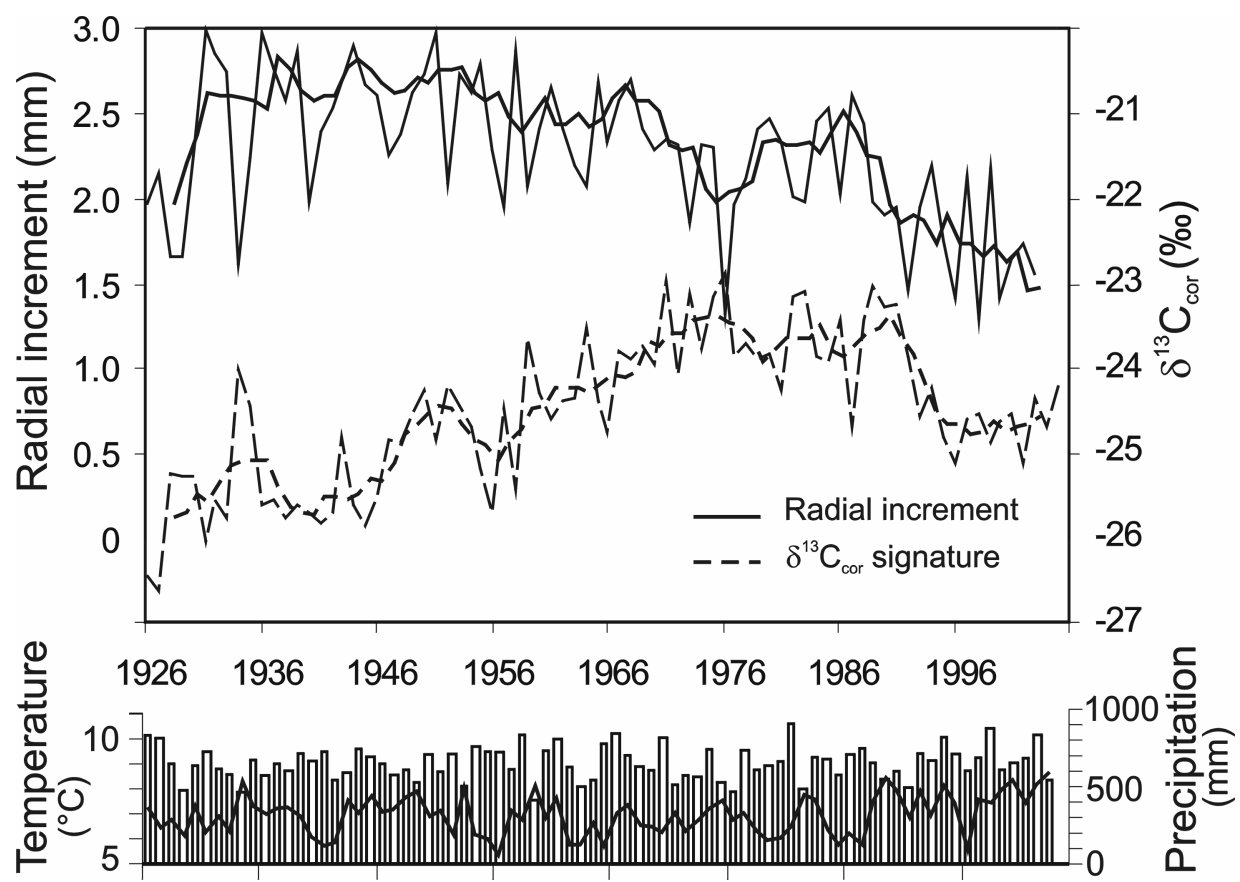

Fig. 2: Chronologies of $\delta^{13} \mathrm{C}_{\text {cor }}$ and radial increment for all 16 Fagus trees (smoothed with a 5 -yr running mean). In addition, annual precipitation totals (bars) and mean annual temperatures are given.

\section{EFFET OF AGE AND TEMPORAL CHANGES IN RADIAL INCREMENT AND $\delta^{13} \mathrm{C}$}

Cambium age was negatively correlated with radial increment $\left(r^{2}=0.67, p<0.001, y=-1.62 x+\right.$ 376.61) regardless of tree age and competition intensity in the neighborhood (Fig. 7). It is noticeable that increment curves defined by the two classes of competition intensity seem to be more congruent than curves referring to younger ( 85 to 116 years) or older trees (119 to 156 years). In contrast, the $\delta^{13} \mathrm{C}_{\text {cor }}$ chronologies revealed a clearer distinction between the two age groups (young vs. old trees) and the two levels of competition intensity (Fig. 8). The correlation of cambial age with the $\delta^{13} \mathrm{C}_{\text {cor }}$ signature was significant and positive when the entire period (1926-2005) was considered $\left(r^{2}=0.43, p\right.$ $<0.001, y=0.007 x-25.18)$.

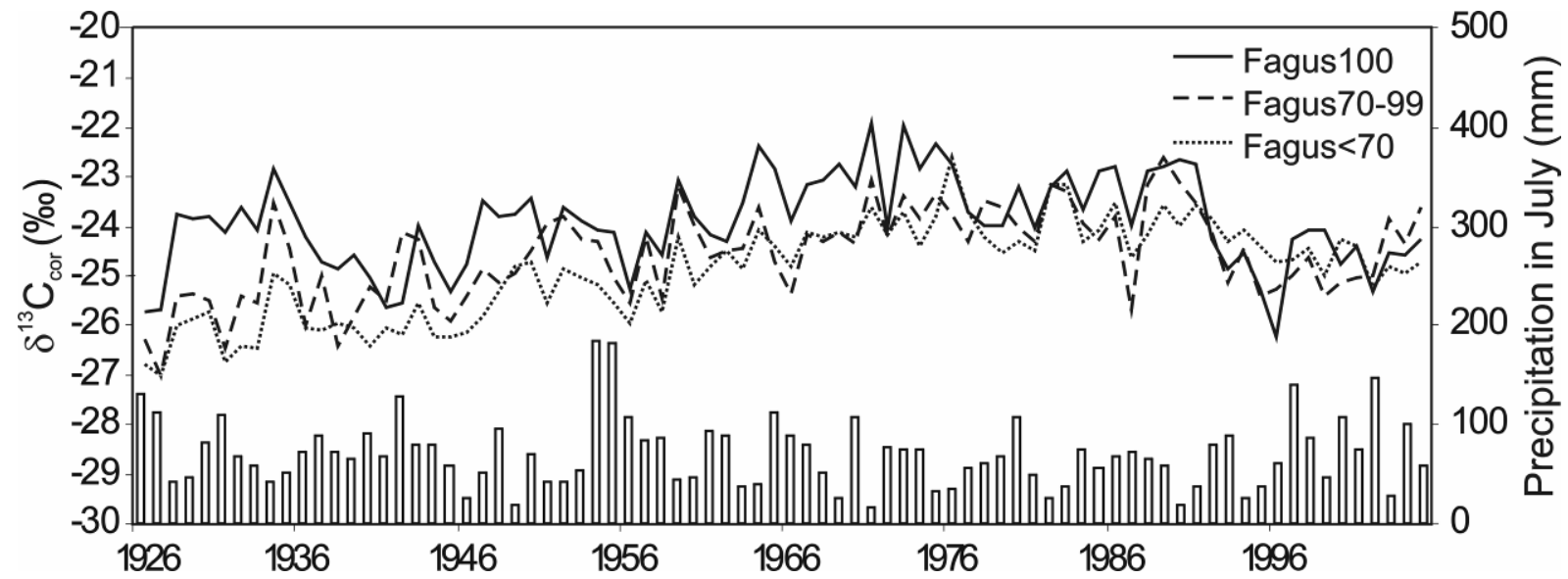

Fig. 3: $\delta^{13} \mathrm{C}$ chronologies of beech (period 1926-2005) corrected for changes in atmospheric $\delta^{13} \mathrm{C}$ (lines) in three different neighborhood categories (only conspecific neighbors: Fagus100, few allospecific neighbor and many Fagus neighbors: Fagus70-99, many allospecific and also Fagus neighbors: Fagus $<70$ ) and corresponding precipitation in July (bars). 


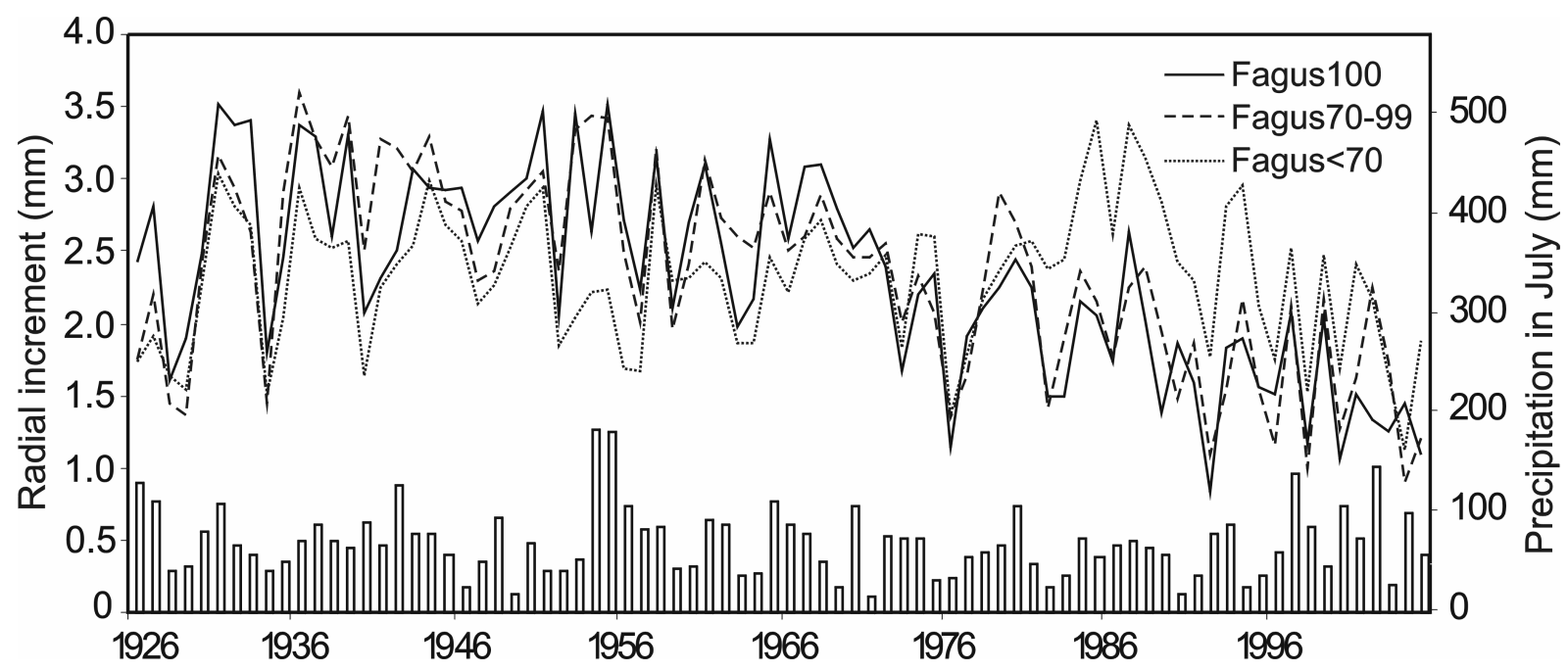

Fig. 4: Ring-width chronologies in three different neighborhood categories (only conspecific neighbors: Fagus 100, few allospecific neighbors, many Fagus neighbors: Fagus70-99, many allospecific and also Fagus neighbors: Fagus $<70)$ and corresponding precipitation in July (bars).

\section{Discussion}

\section{CORRELATION OF CLIMATE PARAMETERS WITH TREE RING $\delta^{13} \mathrm{C}$ SIGNATURES AND RADIAL INCREMENT}

Generally, $\delta^{13} \mathrm{C}_{\text {cor }}$ and ring-width data should reveal a negative correlation because wet conditions in summer lead to better growth (wider tree rings) and a stronger discrimination against ${ }^{13} \mathrm{C}$ (lower $\delta^{13} \mathrm{C}_{\text {cor }}$ values) under conditions of higher leaf conductance. However, in our sample, this relationship partly showed the opposite direction, or the stem increment and $\delta^{13} \mathrm{C}_{\text {cor }}$ data were not correlated at all. Tree individuals with lacking or positive correlation between $\delta^{13} \mathrm{C}$ and ring width were beeches exposed to a relatively high competition intensity $(\mathrm{Cl} 1.12$ to 1.65$)$, and they were generally older than trees showing a negative relationship. One explanation of this mismatch is that ring width and the $\delta^{13} \mathrm{C}$ signature of tree rings are at least partly depending on different environmental factors. While both parameters were influenced by precipitation and temperature in our study, the months with a significant effect were different between the two signals (see Fig. 1). In addition, other factors than climate may also affect the $\delta^{13} \mathrm{C}$ signature including stand thinning (McDowell et al. 2003; Skomarkova et al. 2006) and changes in atmospheric $\delta^{13} \mathrm{C}$ (McCarroll and Loader 2004). Further, $\delta^{13} \mathrm{C}$ typically responds with a longer time lag to environmental fluctuation than does ring width (McDowell et al. 2003, Skomarkova et al. 2006). The latter authors explain the partial mismatch between $\delta^{13} \mathrm{C}$ signal, ring width and climate with the remobilization of stored carbohydrates for growth in the earlier growing season. In their study, only the mid-season $\delta^{13} \mathrm{C}$ value of wood tissue was related to the season's actual climate and associated climatic constraints on assimilation rate. Not surprisingly, beech wood isotope ratios matched modeled isotope ratios in the assimilates only in the mid-part of the growing season while wood growth was found to be disconnected from carbon assimilation during the early and late part of the year (Skomarkova et al. 2006). Contrasting carbon allocation patterns between younger and older 
trees may also be an explanation for our observation that a significant ring width- $\delta^{13} \mathrm{C}_{a c}$ relation existed only in younger beeches.

Only for the $\delta^{13} \mathrm{C}_{\mathrm{ac}}$ signal, all three neighborhood categories showed a uniform response to current year precipitation (in particular that of July). This influence was less clear for ring width which supports our second hypothesis that the isotope signal is more sensitive to climate variation than is ring width, at least with respect to precipitation. A stronger dependence on precipitation of the $\delta^{13} \mathrm{C}$ signal than of ring width has also been observed in other dendrochronological studies at droughtaffected sites (Saurer et al. 1995; Gagen et al. 2004; Andreu et al. 2008). It has also been reported that significant components of a climate signal are included in the $\delta^{13} \mathrm{C}$ values even if ring-width is only poorly correlated with climate data (Robertson et al. 1997). However, $\delta^{13} \mathrm{C}$ is often less sensitive to local site conditions than stem growth parameters (Gagen et al. 2004).

For temperature variation, the situation was different with a closer relation to ring width than to $\delta^{13} \mathrm{C}_{\mathrm{ac}}$ in annual rings. Particularly influential was the temperature of the previous year. For this variable, we found a larger number of significant correlation and response function coefficients than for other thermal parameters. The significance of the temperature climate of the previous year for current wood growth has been explained with stored carbohydrates of the previous year that support radial growth in the following year (Hoshino et al. 2008; Lo et al. 2010). Carbohydrate storage and associated carry-over effects are likely causes not only for the frequently observed correlation of $\delta^{13} \mathrm{C}_{\mathrm{ac}}$ signals with climate parameters of the previous year, but also for the autocorrelation in tree ring width (Skomarkova et al. 2006; Vaganov et al. 2009).

Since our study sites are characterized by pronounced summer droughts (Frech 2006, Guckland et al. 2009), the strong relationship between summer (July) precipitation and $\delta^{13} \mathrm{C}_{a c}$ in tree rings makes it likely that the variation in $\delta^{13} \mathrm{C}_{\mathrm{ac}}$ values in the Hainich forest is a reflection of interannual variation in mean stomatal conductance in the growing season. Drought-induced stomatal closure has been found to significantly influence the canopy carbon gain of temperate broad-leaved trees in drier summers even in the mostly humid climates of Central and Northern Europe (Gagen et al. 2004, Granier et al. 2007). 



Fig. 5: Mean annual radial increment and $\delta^{13} \mathrm{C}_{\text {cor }}$ in annual rings of Fagus trees in the periods 1926-1975 and 1976-2005 in aggregated neighborhood categories (relative contribution of Fagus to competition index $\mathrm{Cl} 70$ - 100\%: Fagus70-100, n $=9$; relative contribution of Fagus to competition index $\mathrm{Cl}$ $<70 \%$ : Fagus $<70, \mathrm{n}=7$ ). Different letters indicate significant differences at $\mathrm{p}<0.05$ (one-sided, non-parametric twosample test after Hothorn 2008).

\section{$\delta^{13} \mathrm{C}$ IN TREE RINGS AS DEPENDENT ON COMPETITION INTENSITY}

Competition can change the intensity of mutual shading among neighboring crowns (Canham et al. 2004) which could influence the $\delta^{13} \mathrm{C}$ signature of tree rings. Indeed, various studies revealed an increase of $\delta^{13} \mathrm{C}$ in tree biomass with increasing irradiance (e.g. Hanba et al. 1997). The structure of tree canopies is influenced by the stem density in the neighborhood and may also depend on the functional traits of neighboring trees (Jack and Long 1991). Therefore, the neighborhood could leave traces in the $\delta^{13} \mathrm{C}$ signature of tree rings. In our study, trees subject to more intense competition by neighboring trees (measured by Hegyi's $\mathrm{Cl}$ ) generally had lower $\delta^{13} \mathrm{C}_{\text {cor }}$ values in their rings, on average by about $0.8 \%$ for $\mathrm{Cl}$ values between 0.94 and 1.72 vs. $\mathrm{Cl}$ values between 0.58 and 0.90 . If competition for water were a key factor, one would expect the opposite, i.e. reduced discrimination of ${ }^{13} \mathrm{C}$ due to lowered stomatal conductance. In a water-limited oak forest, Gouveia and Freitas (2008) found stand density-dependent differences in leaf carbon isotope discrimination and were able to define an optimal stand density from comparisons of $\delta^{13} \mathrm{C}$ signatures in stands differing in stem density. They argued that higher tree densities would lead to increased competition for water resources while lower densities were associated with lower water retention in the ecosystem, since trees in this forest type improve the water storage capacity, resulting in the lowest $\delta^{13} \mathrm{C}$ values at 
moderate tree densities. Thus, a simple positive relationship between competition intensity and $\delta^{13} \mathrm{C}$ is unlikely. Water limitation, as reported for the forests studied by Gouveia and Freitas (2008), is also characteristic for our study site, which is located close to the eastern drought-induced range limit of Fagus in Central Europe (Mölder et al. 2009). We hypothesize that mechanisms leading to reduced drought stress of beech such as self-shading of leaves and shading by other trees (West et al. 2001) may facilitate the existence of Fagus at this site. This effect may mask the expected positive effect of competition intensity on the $\delta^{13} \mathrm{C}$ signature of beech leaf and wood tissue and may result in lowered stomatal limitation.

Another mechanism, which could contribute to the observed pattern in $\delta^{13} \mathrm{C}$ among trees differing in their exposure to competition intensity, is that leaves within the canopy may assimilate $\mathrm{CO}_{2}$ released from respiration of lower canopy strata. Respiration leads to discrimination of ${ }^{13} \mathrm{C}$ (see Berry et al. 1997), thus reducing the abundance of ${ }^{13} \mathrm{CO}_{2}$ in the air and resulting in more negative $\delta^{13} \mathrm{C}$ values in the lower canopy where heterotrophic processes dominate. The lower and upper canopies of forests have been found to differ in atmospheric $\delta^{13} \mathrm{C}$ by $1.7 \%$ to $5.5 \%$ (Sternberg et al. 1989 ; Knohl et al. 2005). Thus, in denser stands with higher $\mathrm{Cl}$, the closer packing of crown elements could lead to an intensified assimilation of ${ }^{13} \mathrm{C}$-depleted $\mathrm{CO}_{2}$. In spite of carry-over effects due to carbon storage, the signal is likely to be manifested in the according tree rings.

\section{COMPETITION WITH CONSPECIFIC VS. COMPETITION WITH ALLOSPECIFIC NEIGHBOR TREES}

For the period 1926 to 1975 , the $\delta^{13} \mathrm{C}$ values of beeches from conspecific neighborhoods were found to be higher than corresponding values of trees in the neighborhood of allospecific competitors. Since intraspecific competition for water between beech trees is likely to be an important factor, allospecific neighbors may facilitate better growth of beech indirectly through reduced water consumption if the neighbors use water more conservatively than beech. In fact, xylem flux measurements in the stem and measurement of leaf conductance in the dominant tree species of the Hainich mixed forest revealed that beech coexists with species that mostly use less water than Fagus when soil moisture content is moderate to high (Hölscher et al. 2005). A higher water availability in more diverse stands should be associated with higher stem increment rates of beech. This, however, was only observed as a tendency in the more recent period $1976-2005$ but not in the $1926-1976$ period. Moreover, the $\delta^{13} \mathrm{C}$ values of the recent period do not show a significant effect of neighborhood diversity. Thus, another factor than neighborhood patterns must have influenced $\delta^{13} \mathrm{C}$ additionally that was active only for the past 30 years. 



Fig. 6: Chronologies of radial increment (a) and $\delta^{13} \mathrm{C}$ (b) in two different classes of competition intensity in the neighborhood of the target trees $(n=8)$. 'Lower competition intensity' stands for Hegyi competition indices $<0.9$, 'higher competition' for $\mathrm{Cl}$ values $>0.9$.

Table 4: $p$-values for the comparison of $\delta^{13} \mathrm{C}_{\text {cor }}$ chronologies of Fagus trees in purely intraspecific neighborhoods (Fagus 100$)$ to Fagus trees neighboring allospecific trees (Fagus $<70$, Fagus70-99). Medians for the series are given in parentheses. Significant differences $\left(p<0.05\right.$, Friedman test) are printed bold. If $\delta^{13} C_{\text {cor }}$ values of Fagus 100 are lower than the compared values from neighborhoods with admixed allospecific trees the relationship is marked with a (-)-sign

\begin{tabular}{|c|c|c|c|c|c|}
\hline Tree & & $\begin{array}{l}\text { Fagus } 100_{1} \\
(-23.22)\end{array}$ & $\begin{array}{l}\text { Fagus } 100_{2} \\
(-24.21)\end{array}$ & $\begin{array}{l}\text { Fagus } 100_{3} \\
(-23.24)\end{array}$ & $\begin{array}{l}\text { Fagus } 100_{4} \\
(-25.30)\end{array}$ \\
\hline Fagus $<70_{1}$ & $(-25.80)$ & $<0.001$ & $<0.001$ & $<0.001$ & 0.025 \\
\hline Fagus $<70_{2}$ & $(-25.16)$ & $<0.001$ & $<0.001$ & $<0.001$ & $0.118 \quad(-)$ \\
\hline Fagus $<70_{3}$ & $(-24.19)$ & $<0.001$ & $0.264(-)$ & $<0.001$ & $<0.001(-)$ \\
\hline Fagus $<70_{4}$ & $(-24.63)$ & $<0.001$ & 0.025 & $<0.001$ & $0.002 \quad(-)$ \\
\hline Fagus $<70_{5}$ & $(-24.07)$ & $<0.001$ & $0.655(-)$ & $<0.001$ & $<0.001(-)$ \\
\hline Fagus $<70_{6}$ & $(-25.72)$ & $<0.001$ & $<0.001$ & $<0.001$ & $<0.001$ \\
\hline Fagus $<70_{7}$ & $(-24.07)$ & $<0.001$ & $0.371(-)$ & $<0.001$ & $<0.001(-)$ \\
\hline Fagus $70-99_{1}$ & $(-26.74)$ & $<0.001$ & $<0.001$ & $<0.001$ & $<0.001$ \\
\hline Fagus $70-99_{2}$ & $(-24.65)$ & $<0.001$ & 0.063 & $<0.001$ & $0.063 \quad(-)$ \\
\hline Fagus $70-99_{3}$ & $(-24.16)$ & $<0.001$ & $0.371 \quad(-)$ & $<0.001$ & $<0.001(-)$ \\
\hline Fagus $70-99_{4}$ & $(-24.66)$ & $<0.001$ & 0.118 & $<0.001$ & $0.025 \quad(-)$ \\
\hline Fagus $70-99_{5}$ & $(-23.12)$ & $0.655(-)$ & $<0.001(-)$ & $1.000(-)$ & $<0.001(-)$ \\
\hline
\end{tabular}





Fig. 7: Chronologies of annual radial increment as dependent on cambium age, the level of competition intensity (a, smoothed with a 5-yr running mean) and tree age (b). Each group contains data from 8 trees. For the calculation of the curves only the analyzed period of 80 years was considered, i.e. information on the early life stage of older trees is not presented. Older trees are $>118$ yrs old. 'Lower competition intensity' stands for Hegyi competition indices $<0.9$, 'higher competition' for $\mathrm{Cl}$ values $>0.9$.

\section{LONG-TERM TRENDS IN $\delta^{13} \mathrm{C}$ AND STEM INCREMENT}

A conspicuous result is the characteristic optimum curve of $\delta^{13} \mathrm{C}_{\text {cor }}$ values since 1926 . The 80 -yr $\delta^{13} \mathrm{C}_{\text {cor }}$ record revealed a period of elevated values between 1965 and 1990 , when the signature was about $1 \%$ higher than before and after this period. The ascending curve might be explained by the 'age effect' when $\delta^{13} \mathrm{C}_{\text {cor }}$ increases in ageing trees with increasing irradiance due to crowns reaching higher canopy strata. Another cause underlying the curve pattern could be changes in atmospheric chemistry over the past decades. We speculate that elevated $\mathrm{SO}_{2}$ concentrations in the atmosphere of Central Europe from the 1960s to the late 1980s may have resulted in partial stomatal closure of sensitive trees, thus decreasing ${ }^{13} \mathrm{C}$ discrimination during photosynthesis (Savard et al. 2004, McNulty 
and Swank 1995; Sakata et al. 2001). The drop in $\delta^{13} \mathrm{C}$ from 1990 to 1995 coincides with a sharp decrease in $\mathrm{SO}_{2}$ concentrations due to strict emission reduction measures in the European Community and especially in the former German Democratic Republic (Thüringer Landesanstalt für Umwelt und Geologie 2002) in that time. Another reason could be the development of denser canopies in the past two decades after selective cutting ceased. A denser canopy is typically linked to reduced $\delta^{13} \mathrm{C}$ values due to lower radiation penetration (Francey and Farquhar 1982) and less stomatal limitation (Farquhar et al. 1989).

In a period when many Central European forests on poorly-buffered soils suffered from acid rain, annual stem increment in the beeches of our stand showed a lasting reduction from about 1985 onwards, and $\delta^{13} \mathrm{C}_{\text {cor }}$ decreased as well. For the Hainich forests on limestone, however, anthropogenic acidification is not a likely cause of this change in growth patterns. Rather, we suggest that forest management practices may have had a substantial influence on both radial growth patterns and the $\delta^{13} \mathrm{C}$ signal. Selective cutting in the stand probably decreased in the 1980 s leading to more intense competition between beech and the other species. Beech trees growing in a species-rich neighborhood (Fagus $<70$ group) had been favored in the past by an extensive selection cutting regime. These trees now faced a more closed and darker stand which simultaneously reduced radial growth and led to lower $\delta^{13} \mathrm{C}$ values (see also Duquesnay et al. 1998). In turn, selective cutting in earlier decades may have increased soil moisture availability due to reduced stand water use (Sucoff and Hong 1974; McDowell et al. 2003) which might have caused reduced $\delta^{13} \mathrm{C}$ signatures in the period before 1975 .

Another reason for the simultaneous decrease in ring width and $\delta^{13} \mathrm{C}$ since 1990 could be elevated summer temperatures since the 1990s which were accompanied by an increasing number of masting events in beech (Schmidt 2006). Frequent masting depletes the carbohydrate resources and leads to reduced radial growth as does the more frequent occurrence of extreme summer heat waves as they happened in 2003 (Granier et al. 2007).

Finally, a possible explanation is also offered by the age effect with a decelerating height and diameter growth in maturing forests as is principally visible in Figs. 7 and 8. Since competition intensity and tree age were negatively correlated in our data set, age could have confounded an assumed effect of $\mathrm{Cl}$ on ring width and $\delta^{13} \mathrm{C}$. However, the limited congruency between the time series of younger and older trees in Fig. $7 \mathrm{~b}$ and $8 \mathrm{~b}$ clearly indicates that other factors such as climate and neighborhood must also be influential.

We conclude that chronologies of width and $\delta^{13} \mathrm{C}$ in annual rings of beech can be significantly influenced by the structure of the tree's neighborhood. However, this signal is typically weaker than the influence of climate variation, tree age and effects of forest management. Current neighborhood constellations are only a snapshot of the community structure, which change substantially over the lifetime of a tree. Nevertheless, for parts of the chronology we obtained evidence of lowered $\delta^{13} \mathrm{C}$ signatures (significant) or elevated radial growth (non-significant tendency) in beeches growing in mainly allospecific neighborhoods as compared to trees in a predominantly conspecific neighborhood. This indicates, at least for certain periods, that beech grew better in mixture than in monoculture in this broad-leaved forest. Since competition intensity was not different between the two neighborhood categories, this effect must have been caused by the specific properties of the neighbors (tree identity) 
or tree diversity. Our study is probably the first to investigate dendrochronological climate archives in their dependence on the simultaneous action of climate, tree age, neighborhood structure, and management effects in a species-rich mixed forest. We suggest that the synchronous analysis of ring width and $\delta^{13} \mathrm{C}$ chronologies for target trees with contrasting neighborhoods may be a promising tool for improving our understanding of the mechanisms of negative and positive interactions between trees in mixed stands.
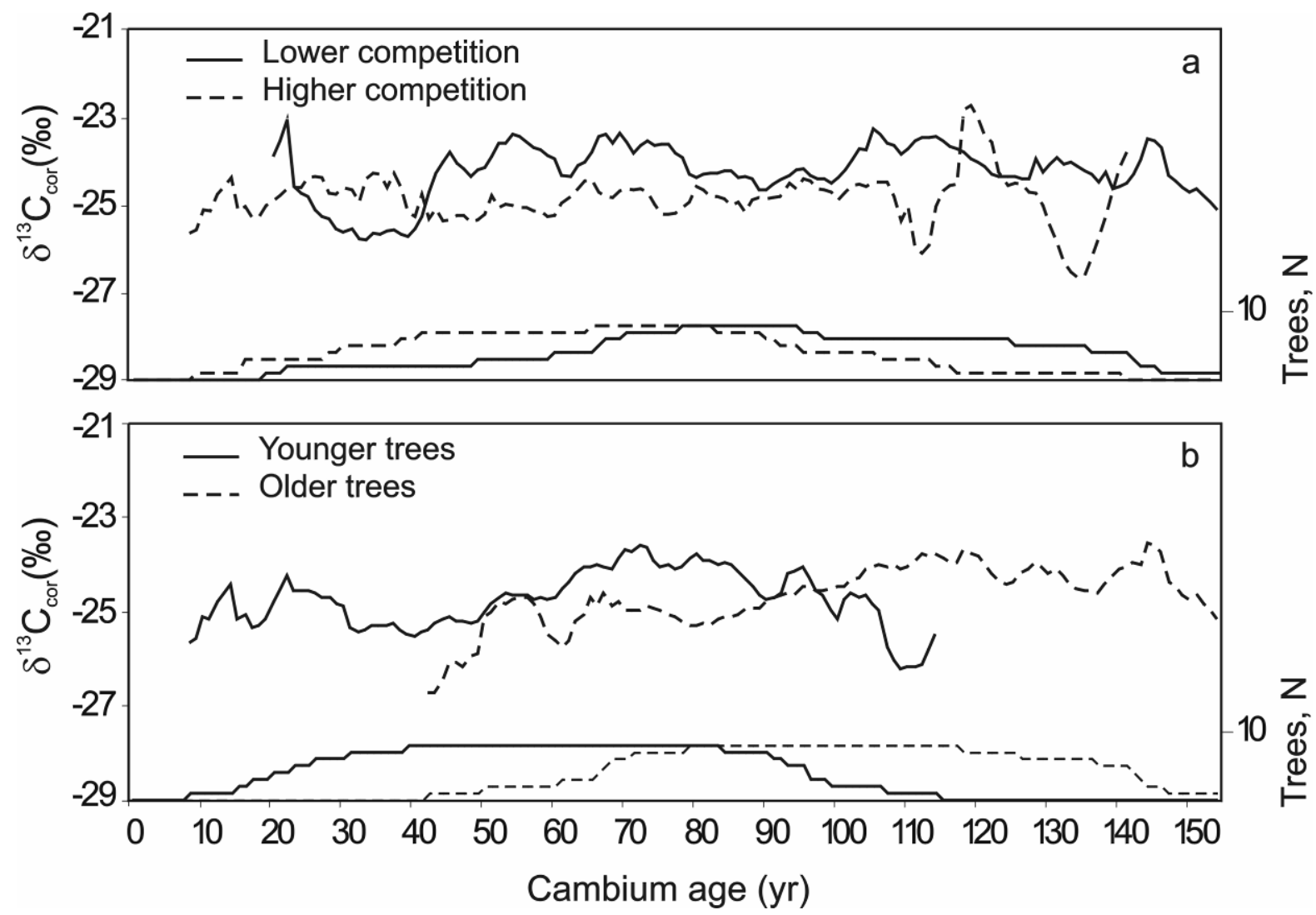

Fig. 8: Chronologies of $\delta^{13} \mathrm{C}$ as dependent on cambium age, the level of competition intensity (a, smoothed with a 5-yr running mean) and tree age. Older trees are $>118$ yrs old. 'Lower competition intensity' stands for Hegyi competition indices $<0.9$, 'higher competition' for $\mathrm{Cl}$ values $>0.9$.

\section{Acknowledgements}

We are grateful to Philippe Marchand for taking hemispheric photos, Laura Rose for support in crossdating tree-ring series, Erika Müller and Gabriele Krisinger for their help in sample preparation and various helpers for stem coring. The study was funded by the German Research Foundation (DFG) within the Research Training Group 1086. 


\section{References}

Andreu L, Planells O, Gutiérrez E, Helle G, Schleser GH (2008) Climatic significance of tree-ring width and $\delta^{13} \mathrm{C}$ in a Spanish pine forest network. Tellus B 60: 771-781

Archaux F, Wolters V (2006) Impact of summer drought on forest biodiversity: what do we know? Ann Forest Sci 63: 645-652

Baillie MGL, Pilcher JR (1973) A simple crossdating program for tree-ring research. Tree-ring Bull 33: 7-14

Berry SC, Varney GT, Flanagan LB (1997) Leaf $\delta^{13} \mathrm{C}$ in Pinus resinosa trees and understory plants: variation associated with light and $\mathrm{CO}_{2}$ gradients. Oecologia 109: 499-506

Biondi F, Qeadan F (2008) Inequality in paleorecords. Ecology 89: 1056-1067

Biondi F, Waikul K (2004) DENDROCLIM2002: A C++ program for statistical calibration of climate signals in tree-ring chronologies. Comput Geosci 30: 303-311

Bréda N, Huc R, Granier A, Dreyer E (2006) Temperate forest trees and stands under severe drought: a review of ecophysiological responses, adaptation processes and long-term consequences. Ann Forest Sci 63: 625-644

Brunner E, Munzel U (2000) The Nonparametric Behrens-Fisher Problem: Asymptotic Theory and a Small-Sample Approximation. Biom J 42: 17-25

Buchmann N, Kao W, Ehleringer J (1997) Influence of stand structure on carbon-13 of vegetation, soils, and canopy air within deciduous and evergreen forests in Utah, United States. Oecologia 110: $109-119$

Canham CD, LePage PT, Coates K.D. (2004) A neighborhood analysis of canopy tree competition: effects of shading versus crowding. Can J For Res 34: 778-787

Canham CD, Papaik MJ, Uriarte M, McWilliams WH, Jenkins JC, Twery MJ (2006) Neighborhood analyses of canopy tree competition along environmental gradients in New England forests. Ecol Appl 16: 540-554

DeClerck FAJ, Barbour MG, Sawyer JO (2006) Species richness and stand stability in conifer forests of the Sierra Nevada. Ecology 87: 2787-2799

Duquesnay A, Bréda N, Stievenard M, Dupouey JL (1998) Changes of tree-ring ${ }^{13} \mathrm{C}$ and water-use efficiency of beech (Fagus sylvatica L.) in north-eastern France during the past century. Plant Cell Environ 21: 565-572

Eckstein D, Bauch J (1969) Beitrag zur Rationalisierung eines dendrochronologischen Verfahrens und zur Analyse seiner Aussagesicherheit. Forstwiss Cent bl 88: 230-250

Farquhar GD, Ehleringer JR, Hubick KT (1989) Carbon Isotope Discrimination and Photosynthesis. Annu Rev Plant Physiol Plant Mol Biol 40: 503-537

FAO/ISRIC/ISSS (1998) World reference base for soil resources. World Soil Resources Rep. 84. FAO, Rome

Francey RJ, Farquhar GD (1982) An explanation of ${ }^{13} \mathrm{C} /{ }^{12} \mathrm{C}$ variations in tree rings. Nature 297: 28-31

Frech A (2006) Walddynamik in Mischwäldern des Nationalparks Hainich - Untersuchung der Mechanismen und Prognose der Waldentwicklung. Ber Forsch zent Waldökosyst (Reihe A) 196: $1-120$ 
Fritts HC (1976) Tree rings and climate. Academic press, London, New York, San Francisco

Gagen M, McCarroll D, Edouard J (2004) Latewood width, maximum density, and stable carbon isotope ratios of pine as climate indicators in a dry subalpine environment, French Alps. Arct, Antarc, Alp Res 36: 166-171

Gouveia AC, Freitas H (2008) Intraspecific competition and water use efficiency in Quercus suber: evidence of an optimum tree density? Trees 22: 521-530

Grams TEE, Kozovits AR, Häberle K, Matyssek R, Dawson TE (2007) Combining $\delta^{13} \mathrm{C}$ and $\delta^{18} \mathrm{O}$ analyses to unravel competition, $\mathrm{CO}_{2}$ and $\mathrm{O}_{3}$ effects on the physiological performance of differentaged trees. Plant Cell Environ 30: 1023-1034

Granier A, Reichstein M, Bréda N, Janssens I, Falge E, Ciais P, Grünwald T, Aubinet M, Berbigier P, Bernhofer C, Buchmann N, Facini O, Grassi G, Heinesch B, Ilvesniemi H, Keronen P, Knohl A, Köstner B, Lagergren F, Lindroth A, Longdoz B, Loustau D, Mateus J, Montagnani L, Nys C, Moors E, Papale D, Peiffer M, Pilegaard K, Pita G, Pumpanen J, Rambal S, Rebmann C, Rodrigues A, Seufert G, Tenhunen J, Vesala T, Wang Q (2007) Evidence for soil water control on carbon and water dynamics in European forests during the extremely dry year: 2003. Agric For Meteorol 143: 123-145

Grissino-Mayer HD, Kaennel Dobbertin M (2003) Dendrochronology Species Database. Names of tree and shrub species for which tree rings have been analysed in the published literature. Eidg. Forschungsanstalt WSL, Birmensdorf.

Guckland A, Jacob M, Flessa H, Thomas FM, Leuschner C (2009) Acidity, nutrient stocks, and organic-matter content in soils of a temperate deciduous forest with different abundance of European beech (Fagus sylvatica L.). J Plant Nutr Soil Sci 172: 500-511

Hanba YT, Mori S, Lei TT, Koike T, Wada E (1997) Variations in leaf $\delta^{13} \mathrm{C}$ along a vertical profile of irradiance in a temperate Japanese forest. Oecologia 110: 253-261

Hegyi F (1974) A simulation model for managing jack-pine stands. In: Fries J (ed) Growth models for tree and stand simulation. Royal College of Forestry, Stockholm, pp 74-90

Hollstein E (1980) Mitteleuropäische Eichenchronologie: Trierer dendrochronologische Forschungen zur Archäologie und Kunstgeschichte. von Zabern, Mainz.

Hölscher D, Koch O, Korn S, Leuschner C (2005) Sap flux of five co-occurring tree species in a temperate broad-leaved forest during seasonal soil drought. Trees 19: 628-637

Hoshino Y, Yonenobu H, Yasue K, Nobori Y, Mitsutani T (2008) On the radial-growth variations of Japanese beech (Fagus crenata) on the northernmost part of Honshu Island, Japan. J Wood Sci 54: $183-188$

Hothorn T, Bretz F, Westfall P (2008) Simultaneous inference in general parametric models. Biom J 50: $346-363$

Jack SB, Long JN (1991) Analysis of stand density effects on canopy structure: a conceptual approach. Trees 5: 44-49

Jactel H, Brockerhoff E, Duelli P (2005) A test of the biodiversity-stability theory: meta-analysis of tree species diversity effects on insect pest infestations and re-examination of responsible factors. In: Scherer-Lorenzen M, Körner C, Schulze E. (eds) Forest Diversity and Function - Temperate and Boreal Systems. Ecological Studies, Springer, Berlin Heidelberg New York, pp. 235-262

Johansson T (1985) Estimating canopy density by the Vertical Tube Method. For Ecol Manage 11: 139-144

Kelty MJ (2006) The role of species mixtures in plantation forestry. For Ecol Manage 233: 195-204

Knohl A, Werner RA, Brand WA, Buchmann N (2005) Short-term variations in $\delta^{13} \mathrm{C}$ of ecosystem 
respiration reveals link between assimilation and respiration in a deciduous forest. Oecologia 142: 70-82

Köcher P, Gebauer T, Horna V, Leuschner C (2009) Leaf water status and stem xylem flux in relation to soil drought in five temperate broad-leaved tree species with contrasting water use strategies. Ann For Sci 66: 101

Larsen J (1995) Ecological stability of forests and sustainable silviculture. For Ecol Manage 73: 85-96

Leuschner C, Jungkunst HF, Fleck S (2009) Functional role of forest diversity: Pros and cons of synthetic stands and across-site comparisons in established forests. Basic Appl Ecol 10: 1-9

Lo Y, Blanco JA, Seely B, Welham C, Kimmins J (2010) Relationships between climate and tree radial growth in interior British Columbia, Canada. For Ecol Manage 259: 932-942

Loreau M, Naeem S, Inchausti P (2002) Biodiversity and ecosystem functioning: synthesis and perspectives. Oxford University Press, New York

Magurran AE (2004) Measuring biological diversity. Blackwell Science, Oxford.

McCarroll D, Loader NJ (2004) Stable isotopes in tree rings. Quat Sci Rev 23: 771-801

McDowell N, Brooks JR, Fitzgerald SA, Bond BJ (2003) Carbon isotope discrimination and growth response of old Pinus ponderosa trees to stand density reductions. Plant Cell Environ 26: 631-644

McNulty SG, Swank WT (1995) Wood $\delta^{13} \mathrm{C}$ as a measure of annual basal area growth and soil water stress in a Pinus strobus forest. Ecology 76: 1581-1586

Medina E, Sternberg L, Cuevas E (1991) Vertical stratification of $\delta^{13} \mathrm{C}$ values in closed natural and plantation forests in the Luquillo mountains, Puerto Rico. Oecologia 87: 369-372

Mitchell TD, Jones PD (2005) An improved method of constructing a database of monthly climate observations and associated high-resolution grids. Int J Climatol 25: 693-712

Mölder A, Bernhardt-Römermann M, Leuschner C, Schmidt W (2009) Zur Bedeutung der Winterlinde (Tilia cordata Mill.) in mittel- und nordwestdeutschen Eichen-Hainbuchen-Wäldern. Tuexenia 29: 9-23

Mölder A, Bernhardt-Römermann M, Schmidt W (2008) Herb-layer diversity in deciduous forests: Raised by tree richness or beaten by beech? For Ecol Manage 256: 272-281

Müller A (2007) Jahrringanalytische Untersuchungen zum Informationsgehalt von HolzkohleRückständen der historischen Meilerköhlerei. Dissertation, University of Freiburg (Breisgau).

Odum EP (1953) Fundamentals of ecology. Saunders, Philadelphia, Pennsylvania, USA.

Orwig DA, Abrams MD (1997) Variation in radial growth responses to drought among species, site, and canopy strata. Trees 11: 474-484

Peterken GF, Mountford EP (1996) Effects of drought on beech in Lady Park Wood, an unmanaged mixed deciduous woodland. Forestry 69: 125-136

Piutti E, Cescatti A (1997) A quantitative analysis of the interactions between climatic response and intraspecific competition in European beech. Can J For Res 27: 277-284

Pretzsch H (1995) Zum Einfluss der Baumverteilungsmusters auf den Bestandeszuwachs. Allg ForstJagdztg 166: 190-201

Pretzsch H (2005) Diversity and productivity in forests: evidence from long-term experimental plots. In: Scherer-Lorenzen M, Körner C, Schulze E (eds) Forest Diversity and Function - Temperate and Boreal Systems. Ecological Studies, Springer, Berlin Heidelberg, pp 41-64 
Robertson I, Rolfe J, Switsur VR, Carter AHC, Hall MA, Barker AC, Waterhouse JS (1997) Signal strength and climate relationships in ${ }^{13} \mathrm{C} /{ }^{12} \mathrm{C}$ ratios of tree ring cellulose from oak in Southwest Finland. J Geophys Res 102: 19507-19516

Sakata M, Suzuki K, Koshiji T (2001) Variations of wood $\delta^{13} \mathrm{C}$ for the past 50 years in declining Siebold's beech (Fagus crenata) forests. Environ Exp Bot 45: 33-41

Saurer M, Siegenthaler U, Schweingruber F (1995) The climate-carbon isotope relationship in tree rings and the significance of site conditions. Tellus B 47: 320-330

Saurer M, Cherubini P, Reynolds-Henne CE, Treydte KS, Anderson WT, Siegwolf RTW (2008) An investigation of the common signal in tree ring stable isotope chronologies at temperate sites. $\mathrm{J}$ Geophys Res 113: G04035

Savard MM, Begin C, Parent M, Smirnoff A, Marion J (2004) Effects of smelter sulfur dioxide emissions: a spatiotemporal perspective using carbon isotopes in tree rings. J Environ Qual 33: 13-26.

Schmidt I, Leuschner C, Mölder A, Schmidt W (2009) Structure and composition of the seed bank in monospecific and tree species-rich temperate broad-leaved forests. For Ecol Manage 257: 695702

Schmidt W (2006) Temporal variation in beech masting (Fagus sylvatica L.) in a limestone beech forest (1981-2004). Allg Forst- Jagdztg 177: 9-19

Skomarkova M, Vaganov E, Mund M, Knohl A, Linke P, Boerner A, Schulze E-D (2006) Inter-annual and seasonal variability of radial growth, wood density and carbon isotope ratios in tree rings of beech (Fagus sylvatica) growing in Germany and Italy. Trees 20: 571-586

Smith KT, Shortle WC (1996) Tree biology and dendrochemistry. In: Dean JS, Meko DM, Swetnam TW (eds) Tree Rings, Environment and Humanity. Proceedings of an International Conference. Radiocarbon, Tucson, AZ., pp 629-635

Sternberg LDSL, Mulkey SS, Wright SJ (1989) Ecological Interpretation of Leaf Carbon Isotope Ratios: Influence of Respired Carbon Dioxide. Ecology 70: 1317-1324

Sucoff E, Hong SG (1974) Effects of thinning on needle water potential in red pine. For Sci 20: 25-29

Thüringer Landesanstalt für Umwelt und Geologie (ed) (2002) Lufthygienischer Jahresbericht 2000. Thüringer Landesanstalt für Umwelt und Geologie, Jena

Vaganov EA, Schulze E, Skomarkova MV, Knohl A, Brand WA, Roscher C (2009) Intra-annual variability of anatomical structure and $\delta^{13} \mathrm{C}$ values within tree rings of spruce and pine in alpine, temperate and boreal Europe. Oecologia 161: 729-745

West AG, Midgley JJ, Bond WJ (2001) The evaluation of $\delta^{13} \mathrm{C}$ isotopes of trees to determine past regeneration environments. For Ecol Manage 147: 139-149

Wulf M (2003) Preference of plant species for woodlands with differing habitat continuities. Flora 198: $444-460$

Yoshida T, Kamitani T (2000) Interspecific competition among three canopy-tree species in a mixedspecies even-aged forest of central Japan. For Ecol Manage 137: 221-230 
Chapter 5

Synthesis 


\section{Synthesis}

\section{Processes altering tree-species diversity and biotic long- term archives at the same time}

Tree-species diversity in Central European forests is mostly a result of forest management. Besides the long-term effect of species diversity, the artificial disturbance linked to forest utilization alters water and light household with consequences for the seed bank (Ebrecht \& Schmidt 2008) and the growth of individual trees (Sucoff \& Hong 1974; McDowell et al. 2003). This could be one explanation for the fact that the seed bank of stands with moderately diverse (DL2) and highly diverse tree layer (DL3) is not only richer in species, but also in the number of germinated seeds (Chapter 2). Herbaceous species characteristic for disturbance occur more frequently in these stands with their specific management history than in pure beech stands (Mölder et al. 2006). Considering the different forest management practices in the monospecific plot (DL1) and the mixed stands (DL2 and DL3), the association of tree species-rich stands with a large and diverse seed bank (DL3) and of pure beech stands with a much poorer seed bank shows parallels to succession towards more stable, less disturbed forests. Ebrecht \& Schmidt (2008) and Van Calster et al. (2008) found a similar trend with higher species numbers in managed or recently disturbed forests in comparison to unmanaged forests or stands with longer management cycles.

Regular thinning is a forest management strategy to reduce competition intensity (in my study measured as competition index $\mathrm{Cl}$ ) which increases the radial growth of the remaining trees (Badeau et al. 1995). I did not find a significant decrease in mean annual increment of Fagus with an increase in $\mathrm{Cl}$, i.e. crowding by neighbor trees, neither on soil with lower nor with higher clay content (Chapter 3). This observation contrasts with the results of other studies in forest stands with variable stem densities, e.g. in Picea mariana (Mill.) B.S.P. stands (Mailly et al. 2003). In fact, tree-species identity and the contribution of different species to the competition index of a Fagus neighborhood were more important in the Hainich forest than the magnitude of $\mathrm{Cl}$ itself.

However, changes in forest management may have influenced the Fagus growth trends in the past 10 to 15 years. In the 1960s to 1990s, the Hainich forest was subject to extensive forest management with a selective cutting regime and the extraction of single stems. The area became a national park with termination of all forest management operations in 1998. Thus, decreasing annual growth rates as observed in many beech trees during the past 8 to 15 years may partly be a consequence of increasing canopy closure which may have increased competition for light in the stands.

Beech trees that are today surrounded by allospecific neighbors probably benefited from thinning in order to foster more valuable broad-leaved tree species. Especially in dry ecosystems thinning is supposed to be linked to an increase in available soil water resulting in increased growth (Sucoff \& Hong 1974; McDowell et al. 2003). This increase in soil water is manifested in relatively smaller $\delta^{13} \mathrm{C}$ values in the allospecific Fagus $<70$ and Fagus70-99 neighborhoods (Chapter 4). Since 
climate is assumed to be the main parameter that influences growth equally over time (Andreu et al. 2008), it seems questionable that a competition index measured in recent times still reflects the situation in former times. Hence, a lasting repeated impact of forest tending can be an explanation for the observed long-term effect of different competition levels on $\delta^{13} \mathrm{C}$.

Competition, as manipulated by forest management, can affect mutual shading levels of crowns (Canham et al. 2004). Different studies revealed an increase of $\delta^{13} \mathrm{C}$ with rising irradiance (Hanba et al. 1997). Tree canopy structure as a function of neighborhood density is therefore likely to leave traces in the $\delta^{13} \mathrm{C}$ signature of tree rings. In my study, trees with higher competition by neighboring trees (measured by Hegyi's $\mathrm{Cl}$ ) had lower $\delta^{13} \mathrm{C}$ values. Since only dominant trees were chosen for the study, target Fagus trees in the class "higher competition" are subject to a relatively moderate competition level. In a water limited ecosystem, Gouveia \& Freitas (2008) found stand densitydependent differences in leaf carbon isotope discrimination and derived an optimal stand density from it. They argued that higher tree densities would lead to increased competition for water resources and lower densities to lower water retention in the areas, resulting in the lowest $\delta^{13} \mathrm{C}$ for moderate tree densities.

\title{
Has tree-species diversity an effect on biotic archives of forest ecosystem processes?
}

\author{
THE SOIL SEED BANK
}

While species composition of the actual vegetation permits to group stands primarily according to geographic distance between the plots, thus reflecting topographic and competition-induced gradients in the forest area, the seed bank composition was better related to the distinction between treespecies poor DL1 and tree species-rich DL2 and DL3 plots. Diversity or tree identity had a much stronger influence on seed bank size and composition than had herb-layer diversity. The strong correlation found between tree- and herb-layer diversity in the Hainich stands would suggest an indirect effect of tree-layer diversity or tree-species identity on the seed bank via herb-layer composition, but this possibility is ruled out due to the poor correspondence between herb-layer composition and seed bank structure.

The effect exerted by certain tree species and tree-species combinations on litter quality and decomposition rate seems to be more influential on the seed bank. Litter may provide a favorable storage medium of seeds if it remains moist throughout the summer. On the contrary, thick layers of slowly decaying leaf litter are known to hamper seedling emergence of many forest floor species, while it can favor the offspring of those species that are able to penetrate through the litter layer, because they suffer from less competition by other species (Sydes \& Grime 1981; Facelli \& Pickett 1991). In the Hainich forest, tree species with rather slow litter decay such as beech co-occur with species like linden, hornbeam and ash with a rapid decomposition (Nordén 1994; van Oijen et al. 2005). My data show a clear negative correlation between seed bank size and litter layer thickness, which makes a causal explanation of seed bank paucity in the DL1 stands by the thick beech litter layer very likely. 
However, seed bank composition and seed germination is not only influenced by litter mass and its persistence on the floor, but also by litter chemistry. Nitrogen- and base-richer leaf litter favors earthworm biomass and diversity in the soil (Reich et al. 2005; Cesarz et al. 2007), promoting seed transport via bioturbation to lower soil horizons. The high number of dicotyledon seeds in $10-20 \mathrm{~cm}$ depth in the DL3 stands is, thus, a consequence of the relatively high earthworm density in these soils. Various authors reported larger seed banks in base-rich forest soils than in base-poor soils (Brown \& Oosterhuist 1981; Staaf et al. 1987). Even though the topsoil pH (KCl) increased in my samples from 3.6 to 3.8 in the DL1 stands to $5.1-5.5$ in the DL3 stands, which can be related to tree-species effects (Mölder et al. 2008), it must remain unclear whether the concomitant increase in seed bank size and diversity is a causal relationship or more coincidence.

\section{RADIAL INCREMENT OF TREES}

This thesis provided dendrochronological evidence that Fagus sylvatica trees show higher mean radial stem growth rates when they are surrounded by a number of other tree species as compared to an entirely conspecific neighborhood. My study is among the first that obtained evidence for a speciesspecific neighborhood effect on the current wood increment rate of a target species in natural forests (compare Bonn 1998; DeClerck et al. 2006). Thus, tree-species diversity or tree identity in the neighborhood, or both, matter for the stem growth of beech, at least on sites in the Hainich forest with soil clay contents $\leq 22 \%$. My results for the 77 beech trees on soil with lower clay content proof a better radial increment of the Fagus $<70$ neighborhood category on the stem level, but not on the stand or tree cluster (neighborhood group) level.

Positive interactions among neighboring trees can lead to a better growth in mixed stands if they are more pronounced in interspecific than in intraspecific interactions (Brooker et al. 2008). Possible mechanisms are nutrient (in particular Calcium) pumping by deeper-rooted species, or the production of nutrient-rich, rapidly decomposing litter which could stimulate growth through a better nutrient supply (Rothe \& Binkley 2001). Beech as a species with a rather high water consumption could also profit from allospecific neighbors which use water more conservatively than does F. sylvatica (Köcher et al. 2009). Thus, allospecific neighbors might facilitate better growth of beech directly by supplying more resources (as may be assumed in the case of nutrients) or indirectly through reduced resource consumption (as for water).

\section{EVAPORATIVE DEMAND OF TREES AS INDICATED BY $\delta^{13} \mathrm{C}$ SIGNATURES}

The strong relationship between summer precipitation and measured $\delta^{13} \mathrm{C}$ values leads to the assumption that the variability of $\delta^{13} \mathrm{C}$ values in my study is controlled by vapor pressure deficit and stomatal conductance, which is typical for water-limited environments (Gagen et al. 2008). 
Allospecific neighbors do not necessarily lead to higher crown overlap. Hence, the effect of denser canopies and shading (Buchmann et al. 1997; Hanba et al. 1997) does not explain $\delta^{13} \mathrm{C}$ differences between neighborhood diversity classes (Fagus100, Fagus70-99, Fagus $<70$ ). In contrast, Frech (2006) found that allospecific neighbors can even decrease overlap due to mechanical interactions of branches. For the period 1926 to $1975, \delta^{13} \mathrm{C}$ values of beeches from mainly conspecific neighborhoods are higher than values of trees in the neighborhood of influential allospecific competitors. Since water is a limiting factor in the Hainich stands, intraspecific competition between beeches for soil water might be the ruling factor. Allospecific neighbors can facilitate better growth of beech indirectly through reduced resource consumption, as for water (Köcher et al. 2009). However, better water supply in more diverse stands should be linked to higher increment rates. Higher increment rates in more diverse stands can only be observed for the later period 1976-2005, whereas $\delta^{13} \mathrm{C}$ values for this period do not show a clear trend with regard to neighborhood diversity. Consequently, an effect of tree-species diversity of the neighborhood on the water supply of Fagus trees can not be indubitably confirmed by $\delta^{13} \mathrm{C}$ signatures.

\section{Effects of tree-species diversity on reaction of Fagus to disturbances}

Fagus trees with a predominantly allospecific neighborhood (Fagus $<70$ category) did not only reach a higher mean annual increment but were also less sensitive in growth to environmental fluctuation, in particular to the severe drought in 2003, as compared to beech trees in pure beech neighborhood. Beeches with a few allospecific neighbors (Fagus70-99 category) reduced growth to a smaller extent in the negative pointer year 1976 than beeches in pure stands and they also recovered more rapidly in terms of stem increment after the 1976 drought. Since 1976 frequency of drought periods increases and especially harms beech on climatically and pedologically marginal sites (Eckstein et al. 1984; Frech 2006). Thus, the presence of allospecific neighbors seems to buffer Fagus trees from environmental hazards which result in growth reductions.

One possible mechanism by which allospecific neighbors may reduce the drought stress sensitivity of a target tree could be a relatively low water consumption of the neighboring trees, as it is the case in F. excelsior (Gebauer et al. 2008; Köcher et al. 2009). Target trees with a higher mean increment as observed in the Fagus $<70$ group are likely to possess an enhanced ability to cope with stressful periods and to recover more rapidly after a stress event (Bonn 1998; Pedersen 1998). Thus, a more open canopy or a better nutrient supply in allospecific neighborhoods are additional putative causes of the lower growth sensitivity in this neighborhood category. While the beech neighborhood seems to influence the growth response of Fagus to certain stress events (e.g., the drought summers 1976 and 2003), it had no significant effect on other growth responses (e.g., to the negative pointer year 1992). Moreover the neighborhood seems to have an only weak or negligible effect on the 26 -yr ring chronologies, i.e. the long-term response types identified by cluster analysis. 
In the period from 1926 to 1975, beech surrounded by mainly conspecifics (Fagus100 and Fagus7099) reached higher values of $\delta^{13} \mathrm{C}$ than beech neighboring influential allospecific competitors (Fagus $<70$ ). On the other hand, values of the more actual period from 1976 to 2005 are indifferent between the neighborhood classes. This leads to the conclusion that target trees today surrounded by allospecific neighbors probably benefited from thinning in order to foster more valuable broad-leaved tree species. Thinning resulted in increased soil water availability and in increased growth (Sucoff \& Hong 1974; McDowell et al. 2003). The effect vanished when the canopy closed again. Hence, the observed pattern is probably rather a secondary effect of forest management than a direct effect of neighborhood diversity on water supply of Fagus.

Generally, I assume that the neighborhood represents an environmental factor which is only secondary to climate variability, soil conditions and light availability as a factor controlling annual ring width. Thus, the neighborhood may influence the growth response under certain conditions, but this factor is too weak to determine principal types in the growth-environment relationship of Fagus. 


\section{References}

Andreu, L., Planells, O., Gutiérrez, E., Helle, G. \& Schleser, G.H. (2008) Climatic significance of treering width and $\delta^{13} \mathrm{C}$ in a Spanish pine forest network. Tellus $B, 60,771-781$.

Badeau, V., Dupouey, J.L., Becker, M. \& Picard, J.F. (1995) Long-term growth trends of Fagus sylvatica $\mathrm{L}$ in northeastern France. A comparison between high and low density stands. Acta Oecologica, 16, 571-583.

Bonn, S. (1998) Dendroökologische Untersuchung der Konkurrenzdynamik in Buchen/EichenMischbeständen und zu erwartende Modifikationen durch Klimaänderungen. Contributions to Forest Science, 3, 1-226.

Brooker, R.W., Maestre, F.T., Callaway, R.M., Lortie, C.L., Cavieres, L.A., Kunstler, G., Liancourt, P., Tielbörger, K., Travis, J.M.J., Anthelme, F., Armas, C., Coll, L., Corcket, E., Delzon, S., Forey, E., Kikvidze, Z., Olofsson, J., Pugnaire, F., Quiroz, C.L., Saccone, P., Schiffers, K., Seifan, M., Touzard, B. \& Michalet, R. (2008) Facilitation in plant communities: the past, the present, and the future. Journal of Ecology, 96, 18-34.

Brown, A. \& Oosterhuist, L. (1981) The role of buried seed in coppicewoods. Biological Conservation, 21, 19-38.

Buchmann, N., Kao, W. \& Ehleringer, J. (1997) Influence of stand structure on carbon-13 of vegetation, soils, and canopy air within deciduous and evergreen forests in Utah, United States. Oecologia, 110, 109-119.

Canham, C.D., LePage, P.T. \& Coates, K.D. (2004) A neighborhood analysis of canopy tree competition: effects of shading versus crowding. Canadian Journal of Forest Research, 34, 778-787.

Cesarz, S., Fahrenholz, N., Migge-Kleian, S., Platner, C. \& Schaefer, M. (2007) Earthworm communities in relation to tree diversity in a deciduous forest. European Journal of Soil Biology, 43, S61-S67.

DeClerck, F.A.J., Barbour, M.G. \& Sawyer, J.O. (2006) Species richness and stand stability in conifer forests of the Sierra Nevada. Ecology, 87, 2787-2799.

Ebrecht, L. \& Schmidt, W. (2008) Bedeutung der Bodensamenbank und des Diasporentransports durch Forstmaschinen für die Entwicklung der Vegetation auf Rückegassen. Forstarchiv, 79, 91-105.

Eckstein, D., Richter, K., Aniol, R.W. \& Quiel, F. (1984) Dendroklimatologische Untersuchungen zum Buchensterben im südwestlichen Vogelsberg. Forstwissenschaftliches Centralblatt, 103, 274289.

Facelli, J. \& Pickett, S. (1991) Plant litter: Its dynamics and effects on plant community structure. The Botanical Review, 57, 1-32.

Frech, A. (2006) Walddynamik in Mischwäldern des Nationalparks Hainich - Untersuchung der Mechanismen und Prognose der Waldentwicklung. Berichte des Forschungszentrums Waldökosysteme (Reihe A), 196, 1-120.

Gagen, M., McCarroll, D., Robertson, I., Loader, N.J. \& Jalkanen, R. (2008) Do tree ring $\delta^{13} C$ series from Pinus sylvestris in northern Fennoscandia contain long-term non-climatic trends? Chemical Geology, 252, 42-51.

Gebauer, T., Horna, V. \& Leuschner, C. (2008) Variability in radial sap flux density patterns and sapwood area among seven co-occurring temperate broad-leaved tree species. Tree Physiology, 28, 1821-1830. 
Gouveia, A.C. \& Freitas, H. (2008) Intraspecific competition and water use efficiency in Quercus suber: evidence of an optimum tree density? Trees, 22, 521-530.

Hanba, Y.T., Mori, S., Lei, T.T., Koike, T. \& Wada, E. (1997) Variations in leaf $\delta^{13} \mathrm{C}$ along a vertical profile of irradiance in a temperate Japanese forest. Oecologia, 110, 253-261.

Köcher, P., Gebauer, T., Horna, V. \& Leuschner, C. (2009) Leaf water status and stem xylem flux in relation to soil drought in five temperate broad-leaved tree species with contrasting water use strategies. Annals of Forest Science, 66, 101.

Mailly, D., Turbis, S. \& Pothier, D. (2003) Predicting basal area increment in a spatially explicit, individual tree model: a test of competition measures with black spruce. Canadian Journal of Forest Research, 33, 435-443.

McDowell, N., Brooks, J.R., Fitzgerald, S.A. \& Bond, B.J. (2003) Carbon isotope discrimination and growth response of old Pinus ponderosa trees to stand density reductions. Plant, Cell \& Environment, 26, 631-644.

Mölder, A., Bernhardt-Römermann, M. \& Schmidt, W. (2006) Forest ecosystem research in Hainich National Park (Thuringia): First results on flora and vegetation in stands with contrasting tree species diversity. Waldökologie-Online, 3, 83-99.

Mölder, A., Bernhardt-Römermann, M. \& Schmidt, W. (2008) Herb-layer diversity in deciduous forests: Raised by tree richness or beaten by beech? Forest Ecology and Management, 256, 272-281.

Nordén, U. (1994) Leaf litterfall concentrations and fluxes of elements in deciduous tree species. Scandinavian Journal of Forest Research, 9, 9 - 16.

van Oijen, D., Feijen, M., Hommel, P., den Ouden, J., de Waal, R. \& Hermy, M. (2005) Effects of tree species composition on within-forest distribution of understorey species. Applied Vegetation Science, 8, 155-166.

Pedersen, B.S. (1998) The role of stress in the mortality of midwestern oaks as indicated by growth prior to death. Ecology, 79, 79-93.

Reich, P.B., Oleksyn, J., Modrzynski, J., Mrozinski, P., Hobbie, S.E., Eissenstat, D.M., Chorover, J., Chadwick, O.A., Hale, C.M. \& Tjoelker, M.G. (2005) Linking litter calcium, earthworms and soil properties: a common garden test with 14 tree species. Ecology Letters, 8, 811-818.

Rothe, A. \& Binkley, D. (2001) Nutritional interactions in mixed species forests: a synthesis. Canadian Journal of Forest Research, 31, 1855-1870.

Staaf, H., Jonsson, M. \& Olsén, L. (1987) Buried germinative seeds in mature beech forests with different herbaceous vegetation and soil types. Holarctic Ecology, 10, 268-277.

Sucoff, E. \& Hong, S.G. (1974) Effects of thinning on needle water potential in red pine. Forest Science, 20, 25-29.

Sydes, C. \& Grime, J.P. (1981) Effect of tree leaf litter on herbaceous vegetation in deciduous woodland. II-An experimental investigation. Journal of Ecology, 69, 249-262.

Van Calster, H., Chevalier, R., Van Wyngene, B., Archaux, F., Verheyen, K. \& Hermy, M. (2008) Longterm seed bank dynamics in a temperate forest under conversion from coppice-with-standards to high forest management. Applied Vegetation Science, 11, 251-260. 


\section{Acknowledgments}

First of all, I would like to thank Prof. Dr. Christoph Leuschner for providing me an interesting and sometimes challenging research topic - many thanks for the constant support and the great interest in my work. Special thanks go to Dr. Hanns Hubert Leuschner for his help and support throughout the last years.

I am grateful to Prof. Dr. Stefan Zerbe for reviewing this thesis and arousing my enthusiasm for plant ecology during one of my first ecology courses.

To all PhD students of the 'Graduiertenkolleg 1086': Thanks a lot for wonderful days of joint field work in Hainich National Park, discussions helping to look "beyond the plate edge" and for becoming good friends. But not only had our own research project made studying the forests of the Hainich so agreeable. I appreciate the cooperation with the management of the Hainich National Park, who gave us the opportunity to work in this wonderful forest. In this context, I would like to thank Eike Kinne and Hans Georgi, who gave valuable information on the management history of our research stands. With regard to local history also Wulf Walther of the Mühlhäuser Museen and Rosemarie Barthel of the Staatsarchiv Gotha made things easier.

Furthermore, I would like to thank the DFG for funding.

To all my colleagues of the Department of Plant Ecology: thank you for the very nice working atmosphere and entertaining lunch breaks. Field work would have been much harder without Heiko Eichner, Heiko Rubbert, Dr. Heinz Coners, Nicolai Brock, Marcel Tillmann, Erika Müller, Gabriele Krisinger and Alena Vacátková, Arantzazu Blanco Bernadeau, Christoph Zabel - thank you very much. Further, I would like to thank Philippe Marchand and Kieran McDonald for their very useful work in Göttingen.

Special thanks to Dr. Mascha Jacob and Dr. Tobias Gebauer for sharing also late office hours with fruitful discussions and a lot of fun.

Without the big support of many people, finishing this $\mathrm{PhD}$ thesis would have been impossible. Many thanks to:, Dr. Nadine Weland, Dr. Catharina Meinen, PD Dr. Hermann F. Jungkunst, Dr. Stefan Fleck, Prof. Dr. Wolfgang Schmidt, PD Dr. Dirk Gansert, Peter Herreid, Laura Rose, Prof. Dr. Hermann Behling and Prof. Dr. Hartmut Laatsch.

Ein besonderer Dank geht an meine Eltern Ingrid and Erich Schmidt für ihre Unterstützung, diverse Doktorandenversorgungspakete und ihren Willen mein Interesse für Jahrringe und Bodensamenbanken zu teilen.

Finally, special thanks to my husband Dr. Andreas Mölder for the endless and invaluable support, for extending my interest in ecological history back to the Cretaceous, his enthusiasm in my historical $\mathrm{PhD}$ topic and his love. 


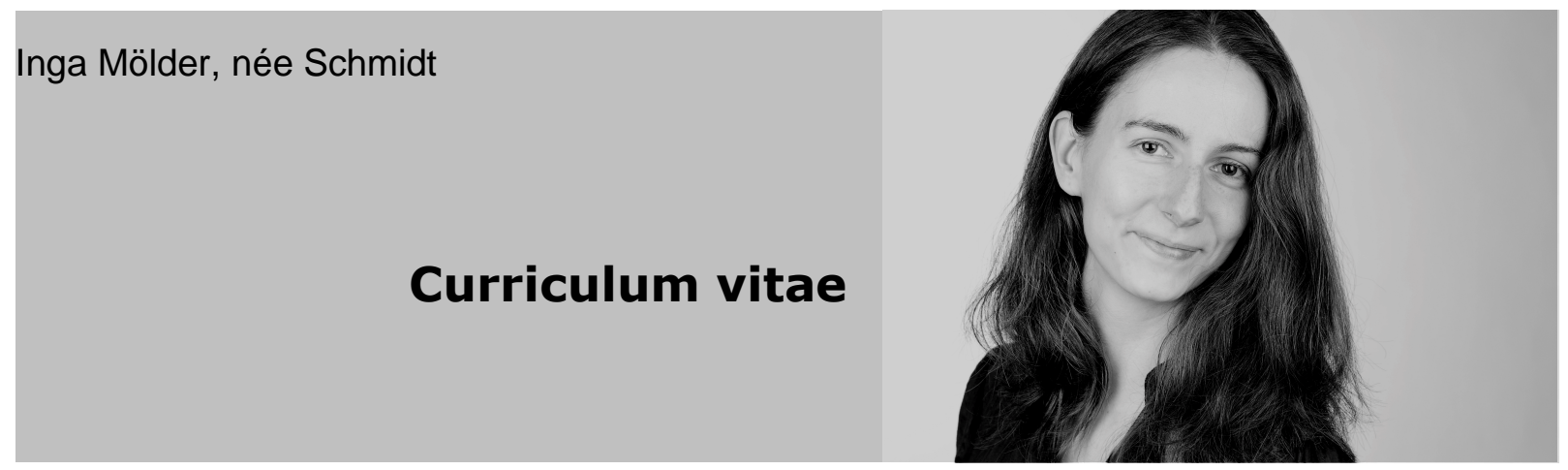

\section{Work experience}

05/2009 until now Scientist at the Northwest German Forest Research Station, Research project "Further Development and Implementation of an EU-level Forest Monitoring System" (FutMon)

04/2009 to 05/2009 Teaching assistant for biology: "Biologie für Studenten der Medizin", GeorgAugust University Göttingen, Albrecht-von-Haller-Institute for Plant Sciences

04/2005 to 03/2009 PhD project „Diversity and tree neighborhood effects on the growth dynamics of European beech and the stand seed bank in temperate broad-leaved forests of variable tree diversity", Georg-August University Göttingen, Albrecht-von-Haller-Institute for Plant Sciences, Department of Plant Ecology and Ecosystems Research. Research training group 1086 "The role of biodiversity for biogeochemical cycles and biotic interactions in temperate deciduous forest".

04/2006 to 07/2008 Teaching assistant for statistics: "Statistik für Biologiestudierende", „Einführung in die Biostatistik mit R“, Georg-August University Göttingen, Institute for Microbiology and Genetics, Department of Bioinformatics.

04/2003 to 03/2005 Student assistant: "Biologische Vielfalt und deren Bewertung" (BioTeam), Technical University of Berlin, Institute for Landscape and Environmental Planning, Chair in Environmental and Land Economics

02/2002 to 05/2002 Student assistant: "Stromlandschaft Elbe", Technical University of Berlin, Institute for Landscape and Environmental Planning, Chair in Environmental and Land Economics

\section{Education}

$04 / 2005$ to $03 / 2009$

08.12 .2004

$10 / 1998$ to $12 / 2004$

$08 / 2003$ to $12 / 2003$

$08 / 1991$ to $07 / 1998$

\section{PhD program "Biological Diversity and Ecology"}

Diploma "Diplom-Ingenieur der Landschaftsplanung"

Diploma thesis: "Biodiversity indicators in forest ecosystems - the Solling mountains (Germany) as an example"

Study program in landscape planning, Technical University of Berlin

Stay abroad at the University of Wisconsin - Madison /USA (Urban Ecology: Educating for the Management of Cultural Landscapes Exchange Program)

High school examination (Abitur), Gymnasium "Otto von Guericke", Magdeburg 